\title{
Energy Conservation Potential of Surface Modification Technologies
}

September 1985

Prepared for the U.S. Department of Energy under Contract DE-AC06-76RLO 1830

Pacific Northwest Laboratory Operated for the U.S. Department of Energy by Battelle Memorial Institute 


\title{
DISCLAIMER
}

This report was prepared as an account of work sponsored by an agency of the United States Government. Neither the United States Government nor any agency thereof, nor any of their employees, makes any warranty, express or implied, or assumes any legal liability or responsibility for the accuracy, completeness, or usefulness of any information, apparatus, product, or process disclosed, or represents that its use would not infringe privately owned rights. Reference herein to any specific commercial product, process, or service by trade name, trademark, manufacturer, or otherwise, does not necessarily constitute or imply its endorsement, recommendation, or favoring by the United States Government or any agency thereof. The views and opinions of authors expressed herein do not necessarily state or reflect those of the United States Government or any agency thereof.

\author{
PACIFIC NORTHWEST LABORATORY \\ operated by \\ BATTELLE \\ for the \\ UNITED STATES DEPARTMENT OF ENERGY \\ under Contract DE-AC06-76RLO 1830
}

\begin{tabular}{|c|c|}
\hline \multicolumn{2}{|c|}{ Printed in the United States of America } \\
\hline \multicolumn{2}{|c|}{$\begin{array}{c}\text { Available from } \\
\text { National }\end{array}$} \\
\hline \multirow{2}{*}{\multicolumn{2}{|c|}{$\begin{array}{l}\text { National Technical Information Service } \\
\text { United States Department of Commerce }\end{array}$}} \\
\hline & \\
\hline \multicolumn{2}{|c|}{5285 Port Royal Road } \\
\hline \multicolumn{2}{|c|}{ Springfield, Virginia 22161} \\
\hline \multirow{2}{*}{\multicolumn{2}{|c|}{$\begin{array}{l}\text { NTIS Price Codes } \\
\text { Microfiche } A 01\end{array}$}} \\
\hline & \\
\hline \multicolumn{2}{|c|}{ Printed Copy } \\
\hline & Price \\
\hline Pages & \\
\hline 001-025 & A02 \\
\hline 026-050 & A03 \\
\hline 051-075 & A04 \\
\hline $076-100$ & A05 \\
\hline $101-125$ & A06 \\
\hline $126-150$ & A07 \\
\hline $151-175$ & $\mathrm{~A} 0 \mathrm{~B}$ \\
\hline $176-200$ & A09 \\
\hline $201-225$ & $\wedge 010$ \\
\hline $226-250$ & A011 \\
\hline $251-275$ & $\wedge 012$ \\
\hline $276-300$ & $\wedge 013$ \\
\hline
\end{tabular}


ENERGY CONSERVATION POTENTIAL OF

$H$. K. Le

ก. M. Horne

R. S. Silberglitt

DHR, Incorporated

T. M. Levinson

DOE/ECUT Program Manager

September 1985

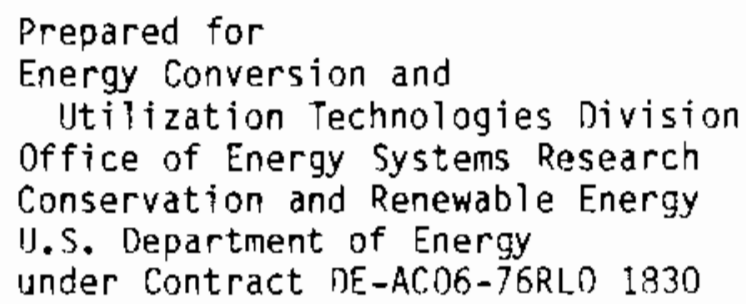

Pacific Northwest Laboratory

Richland, Washington 99352 

Experts estimate that in 1978 over four quadrillion Btu of energy were lost in the United States because of simple friction and wear--enough energy to supply New York City for an entire year. This translates to a $\$ 20$ billition loss, based, on oil prices of about $\$ 30$ per barrel. (a) Because of the enormity of this energy loss, the Energy Conversion and Utilization Technologies (ECUT) Program in the U.S. Department of Energy (DOE) initiated a program in 1983 to study tribology--the science of friction and wear--to learn more about the causes of these energy losses (or tribological "sinks") and how to reduce them.

The ECUT Program itself was started in 1980 to encourage research to improve energy conversion and utilization efficiency. The enormous energy loss in tribological sinks has been targeted by the ECUT program as having significant potential for energy conservation. One goal of the ECUT Tribology Program is to reduce these energy losses by developing improved lubricants and more durable materials.

To support initial Tribology Program planning, ECUT conducted six surveys to gather three types of information about the current tribology problem in the U.S.:

1. The identification of typical industrial sinks

2. A survey of current U.S. Government tribology projects

3. The identification of tribology R\&D needs based on industry perceptions.

The six ECUT-sponsored surveys are listed in Table ES.1. Each survey is being published as a separate volume with its own summary. This executive sumary, which also appears in each of the six volumes, presents an overview of results from the six surveys and their implications for energy conservation. The results of these six surveys and thei $r$ implications for energy conservation are presented in this summary. These results will be used to support further research planning for the ECUT Tribology Program.
TABLE ES.1. ECUT Surveys Revi ewed in this Summary

1. A Review of Tribological Sinks in Six Major Industries. Imhoff, et a). PNL-5535, Pacific Northwest Laboratory, Richland, Washington.

2. Reduction in Tribological Energy Losses in the Transportation and Electric Utilities Sectors. Pinkus and Wilcock, Mechanical Technology Incorporated. PNL-5536, Pacific Northwest Laboratory, Richland, Washington.

3. Identification of Tribological Research and Development Needs for Lubrication of Advanced Heat Engines. Fehrenbacher, Technology Assessment and Transfer, Incorporated. PNL-5537, Pacific Northwest Laboratory, Richland, Washington.

4. Energy Conservation Potential of Surface Modification Technologies. Le, DHR, Inc. PNL-5538, Pacific Northwest Laboratory, Richland, Washington.

5. Assessment of Government Tribology Programs. Peterson, Wear Sciences Corporation. PNL-5539, Pacific Northwest Laboratory, Richland, Washington.

6. Assessment of Industrial Attitudes Toward Generic Research Needs in Tribology. Sibley and Zlotnick, Tribology Consultants Incorporated. PNL -5540 , Pacific Northwest Laboratory, Richland, Washington.

IDENTIFYING TYPICAL TRIBOLOGICAL SINKS AND MECHANISMS

ECUT's first step in collecting information about tribology was to identify significant tribological sinks and mechanisms. This information was needed to focus research on key technological problems. Because the industry, transportation, and utilities sectors account for most of the

(a) Calculations in this summary are based on a $\$ 30$ figure. 
energy consumed in the U.S., ECUT concentrated first on the tribological energy sinks and mechanisms found in these three sectors. The report by Imhoff, et al., describes the most important tribological sinks typically found in industry, and the report by Pinkus and Wilcock describes tribological energy losses in the transportation and utilities sectors. Two specific studies assessed tribological problems in the metalworking industry and in the advanced diesel engine.

To identify areas in which tribology has a significant impact, the authors examined the energy consumed, the fuels used, and the primary products and processes found in the transportation, industrial, and utilities sectors. Once energy losses were identified, their magnitude was estimated. The estimates include both friction losses (direct losses) and material wear losses (imdirect losses). The authors also estimated the energy savings potential in each sector and recommended some specific R\&D programs to help achieve these energy savings.

\section{The Industrial Sector}

Tribological energy losses are pervasive throughout industry. Because reviewing all industries and industrial processes in detail would be impossible, the Imhoff, et al. survey, instead chose six representative industries (Mining, Agriculture, Primary Metals, Chemicals/Refining, Pulp and Paper, and Food Processing) that appeared to have the most significant tribological sinks and energy losses. These industries were selected because of their 1) major, nonthermal energy streams (such as machine drives); 2) high material wear rates and friction; 3) significant material transportation/alteration processes; and 4) total energy use.

The study identified important tribological sinks in each selected industry, based on both friction and material wear energy losses and on the tribological mechanisms and materials involved. Figure ES.1 and Table ES.2 show the key results for each of the six industries.

The first conclusion from this study confirmed earlier claims that losses from material wear are greater than energy losses from friction; the wear losses in five of the industries were found to be more thap twice as large as the friction losses. (a) The study also concluded that reducing material wear rates to improve equipment life

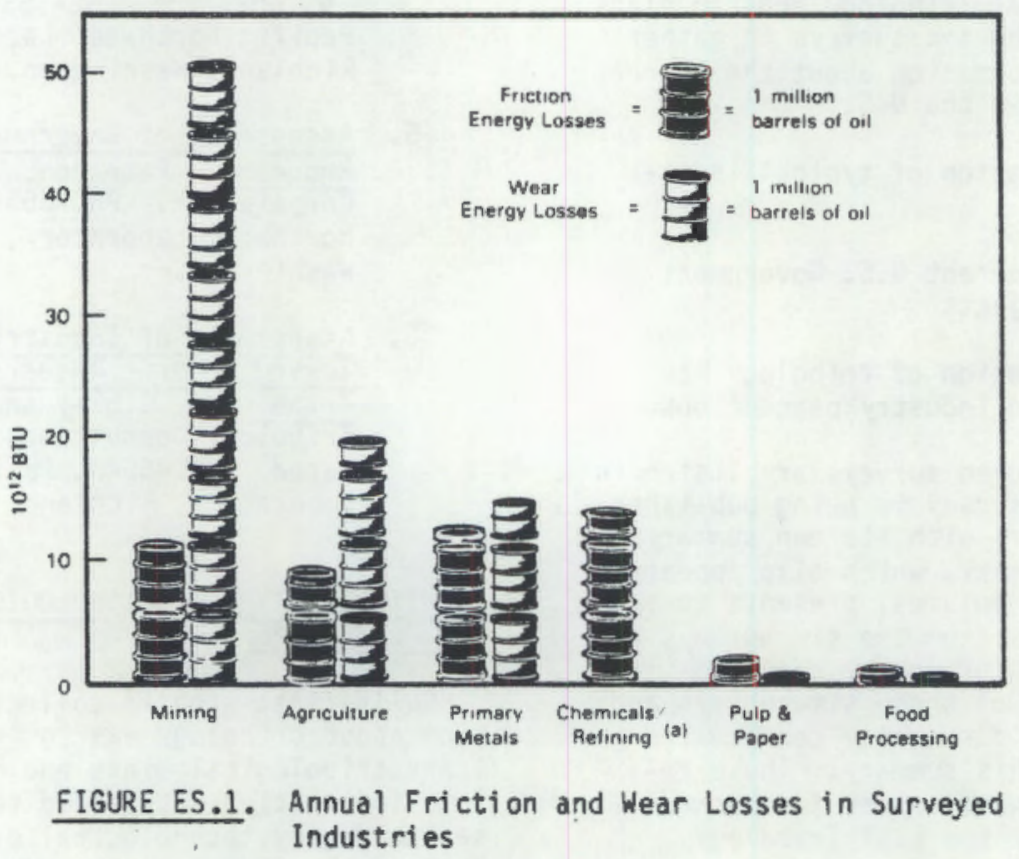

(a) These five industries had estimates of both friction and material wear losses; the sixth, Chemicals/Refining, did not have estimates of wear losses. 
TABLE ES.2. Primary Mechanisms in Friction Energy Losses and Principal Materials Involved in Wear Energy Losses

\begin{tabular}{|c|c|}
\hline Industry & Mechanis \\
\hline Mining & $\begin{array}{c}\text { 3-body Abra } \\
\text { Friction }\end{array}$ \\
\hline Agricuiture & $\begin{array}{c}\text { 3-body Abra } \\
\text { Friction }\end{array}$ \\
\hline Primary Metals & $\begin{array}{l}\text { Hot Rolli } \\
\text { Ineffic }\end{array}$ \\
\hline Chemi cals/Refining & $\begin{array}{c}\text { Friction, } \\
\text { Abrasion }\end{array}$ \\
\hline Pulp \& Paper & Friction \\
\hline Food Processing & Erosion, $\mathrm{Ab}$ \\
\hline $\begin{array}{l}\text { ity would also sign } \\
\text { istrial productivity } \\
\text { tatives interviewed } \\
\text { he positive impacts } \\
\text { search could have o }\end{array}$ & $\begin{array}{l}\text { cantly } \\
\text { The indus- } \\
\text { trongly } \\
\text { hat tri- } \\
\text { operational }\end{array}$ \\
\hline
\end{tabular}

\section{Tribology in the Metalworking Industry}

In addition to the general review of tribological sinks in industry, ECUT sponsored a more specific study of tribology in the metalworking industry by Le Xhac at DHR, Inc. The study estimated the energy conservation potential of using advanced surface modification technologies in this industry. These surface modification technologies are thermal, chemical, or mechanical treatments that reduce friction and wear at a material's surface without changing its bulk properties. The advanced surface modification technologies considered were ion implantation, laser surface hardening, electron beam surface hardening, and wearresistant coating deposition. The author studied 70 percent of the metal-forming and metal-cutting machines used in the United States (except those associated with primary metals processing), identified tribological mechanisms, and estimated friction and wear energy losses. Potential energy savings from using surface-modified tools were also estimated.

The metal-forming machines studied were punches, presses and forges, and the metalcutting machines studied were turning,
Materials

Iron, Steel \& alloys, Alumi num, Rubber

Steel, Rubber, Lubricants

Steel \& alloys

Not studied

Steel \& alloys, ChromiumMolybdenum alloys Grinding stones

Steel \& alloys drilling, milling, broaching, and sawing machines. Models were developed to estimate friction and wear energy losses and potential savings. The friction losses were estimated by adding friction losses at the motor drive system and at the tool-workpiece interface. Estimates of energy consumption were based on standard operating conditions (known friction coefficients, total working time, etc.) The indirect losses from wear were estimated based on the replacement costs of all metalworking tools used and discarded in one year.

Based on actual experimental or production data, the author estimated that the friction losses in all U.S. metalworking machines amount to $20.2 \times 10^{12}$ Btu per year, or $\$ 104.5$ million. Of this energy loss, $1.8 \times$ 1012 Btu per year, or $9 \%$, could be saved using surface modification technologies to reduce friction. The wear loss was

estimated to be $7.7 \times 10^{12}$ Btu per year. (a) Possible energy savings using surface modification technologies to reduce wear could conserve $5.5 \times 10^{12}$ Btu per year, or $71 \%$.

Finally, the author estimated that tribological energy losses in all U,S. metalworking machines total $27.9 \times 10^{12}$ Btu, equivalent to 4.8 million barrels of oil or $\$ 144$ million annually. More than a quarter of this loss could be saved using surface modification technologies to reduce friction and wear. These results are shown in Figure ES.2.

(a) Using 19.2 million Btu per ton as the embodied energy in steels. 


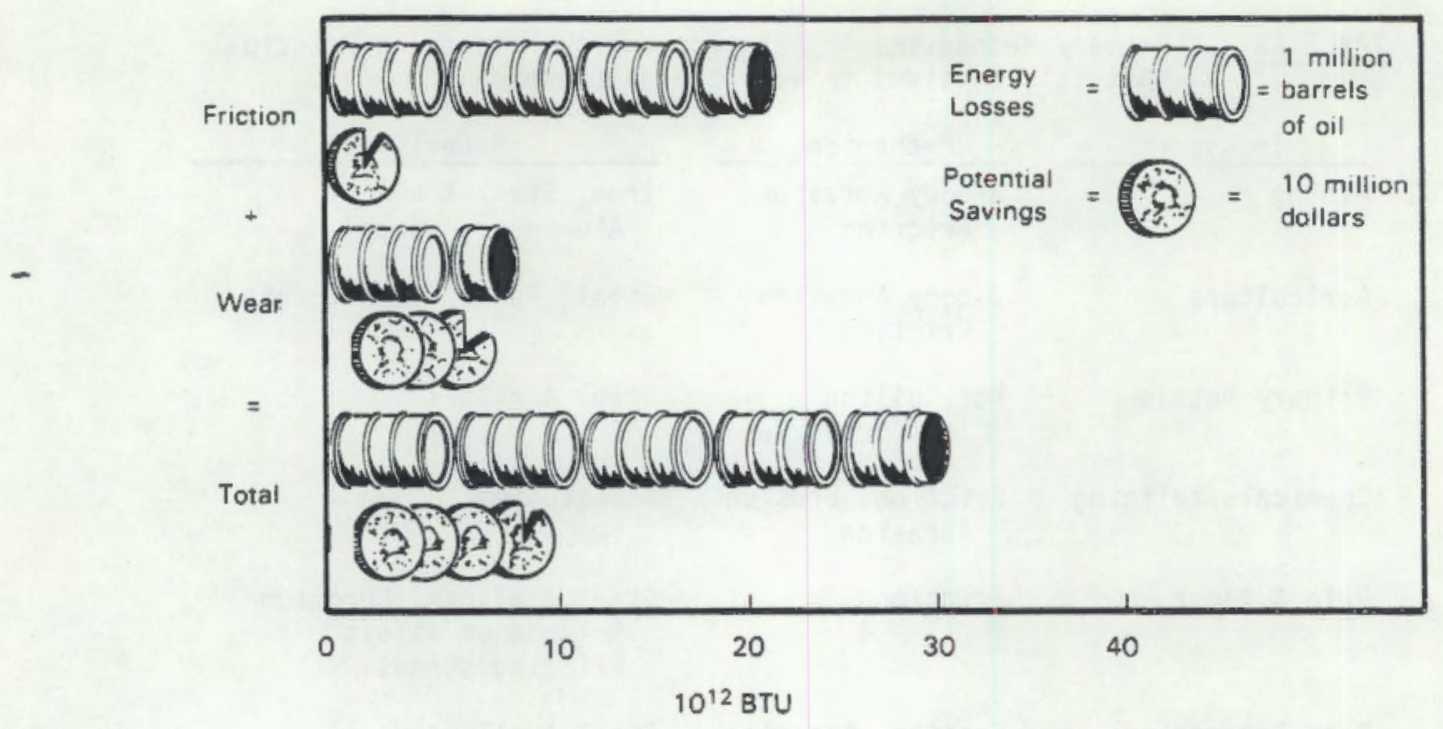

FIGURE ES.2. Annual Friction and Wear Energy Losses in the Metalworking Industry, and Potential Savings from Surface Modification Technologies

The Transportation Sector

The transportation sector is important both in terms of its energy consumption $(26 \%$ of tota] U.S. annual energy consumption, or $19 \times 10^{15} \mathrm{Btu}$, equivalent to $\$ 98$ billion), and because of the high level of tribological losses. The Pinkus and Wilcock study primarily focused on the highway fleets (passenger cars, buses and trucks), which consume $77 \%$ of the total energy used in the transportation sector. The survey primarily addressed the conventional otto cycle engine. However, other concepts were also considered, such as the adiabatic diesel, the gas turbine, and the Stirling engine; in addition, the fehrenbacher report evaluated tribological activity in advanced diesel engines.

Figure ES. 3 shows the principal automotive tribological sinks and the estimated energy savings. The principal automotive energy sinks are caused by the mechanical inefficiency of the engines and drive trains; most of the energy losses are due to friction.

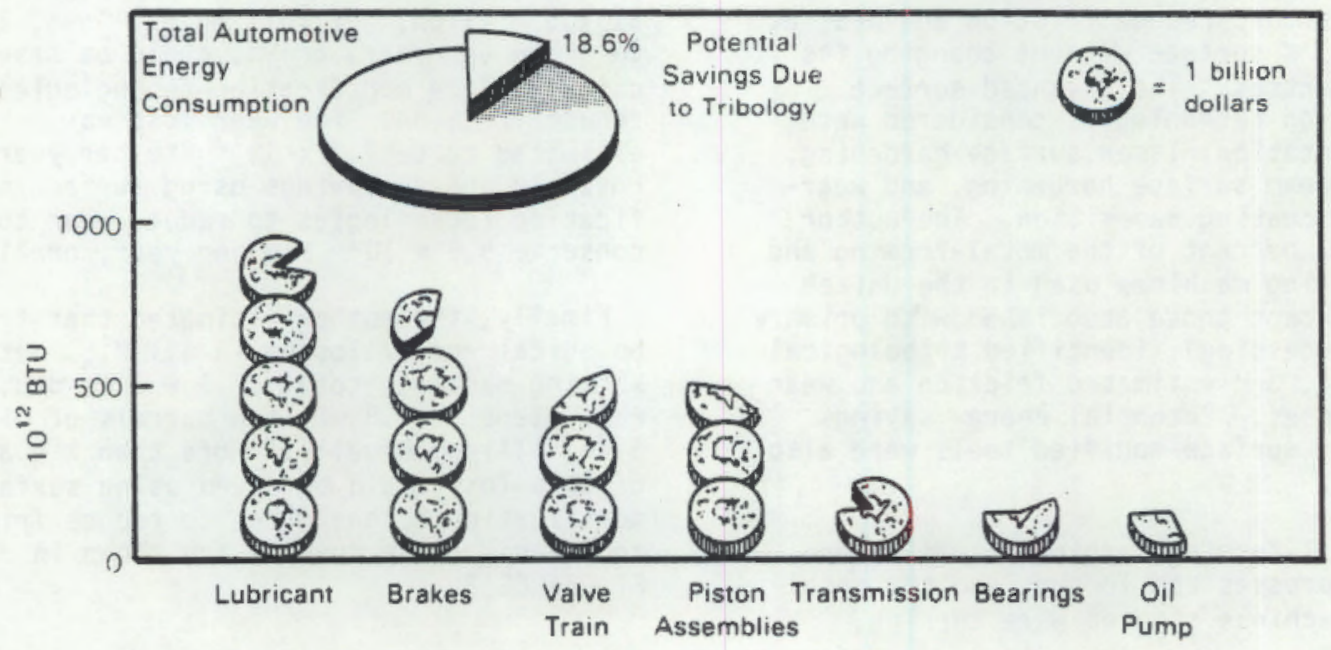

FIGURE ES.3. Potential Energy Savings Per Year for the Conventional Engine (8ased on highway fleet size in 1976) 
The survey by Pinkus and Wilcock revealed several tribological areas of particular concern for conventional engines, such as the piston ring assembly and the long-range effect of low-viscosity oil on engine wear. As shown in Figure ES.3, tribological improvements could save $18.6 \%$ of the total annual energy consumed by automobiles, or $\$ 14.3$ billion.

Research on conventional engines often applies to unconventional engines as well. Except for the adiabatic diesel, the energy savings possible from tribological improvements to unconventional engines are less significant than those of the conventional otto cycle engine. The major problems in unconventional engines are related to hightemperature tribological problems. Introducing adiabatic and mi nimum friction engines into the bus and truck fleets of the U.S. could save up to $2.9 \%$ of total U.S. energy consumption.

This survey also revealed the difficulties with devising adequate performance tests to quantify energy losses and evaluate new designs and products. Laboratory tests that accurately reflect real-world conditions are badly needed. The ability to test entire systems is vital, since tribological energy losses are often caused by complex interactions between all the components of a system.

\section{Advanced Diesel Engines}

Because of the great potential for energy savings, the ECUT study by Fehrenbacher examined the lubrication of advanced diese? engines in detail. The efficiency of these engines could be improved by about $10 \%$; however, higher operating temperatures $\left(1000^{\circ} \mathrm{F}\right.$ and higher in the upper cylinder area) are requi red to reach this greater efficiency. As a result, the primary development challenge for these engines concerns friction, wear, and lubrication of the upper cylinder region. In fact, tribological advancements in these areas are essential if diesel engine performance and durability goals are to be reached. This study assessed these vital tribological concerns in both current and future technologies and recommended tribology R\&D topics for further advanced engine development.

Both the mechanical design of the upper cylinder and the chemical effects of lubricants and fuel determine the friction and wear characteristics of the upper cylinder region. These two factors interact in a complex and sometimes synergistic manner. The geometry of the piston, piston ring, and cylinder directly affect the rate and nature of deposit formation, oil consumption, and friction. Efforts have been made to optimize the upper cylinder geometry in current diesel engine technology; this will also be a critical area in future developments. However, problems with upper cylinder deposits, bore polishing, and oil consumption still exist. This study indicates that these problems are caused by the chemical interactions between upper cylinder materials, oil degradation products, and fuel combustion by-products. Therefore, lubricants, oil degradation rates, and mechanisms will continue to be important research areas.

Although a great deal of research has been conducted on liquid lubricants, in most cases the lubricants have been tested without considering the tribological factors specific to the upper cylinder. Since the lubricants interact with the materials and envir ronment of the upper cylinder, they must be developed and tested under similar conditions.

The ECUT study also pointed out that future advanced engine concepts will require ceramic upper cylinder materials able to withstand the higher operating temperatures. New lubricants will have to be developed, and solid lubricants are likely to play a major role. A major research effort will be needed in this area; again, the research must be conducted on a total system basis to be most effective.

The study concluded that many problems with current diesel engines will continue to exist in advanced diesel engines. Tribological problens in the upper cylinder region will be most critical in terms of engine performance and wear. Lubricant R\&D is still a major research area in current technology, but total system materials and design considerations should be emphasized. Advanced diesel concepts will requi re new design approaches, but the tribology of the upper cylinder region will still be critical and may even be the limiting factor in achieving higher engine efficiencies. Extensive materials R\&D wlll be requi red for advanced designs as well, especially in ceramics, ceramic composites and solid lubricants.

\section{The Utilities Sector}

The utilities sector was also reviewed for significant tribology sinks. This sector accounts for roughly $28 \%$ of total U.S. energy consumption. ECUT's review revealed that tribological improvements in efficiency and reliability could save $2.3 \%$ of the total energy annually consumed by utilities, or about $\$ 2.5$ billion. As in the transportation sector, efficiency is a major factor. 
However, reliability (especially in generating units) is just as important for energy conservation.

The data used in these studies were primarily for the utilities' power plants. The average power plant operates at an efficiency (output energy/input emergy) between 30 and $40 \%$. Mechanical losses account for $17-26 \%$ of the total energy used. Reliability problems that lead to generator shutdown require using standby equipment, which generally has less efficient fuel consumption. This causes losses both in terms of fuel economy, and revenue and labor costs. Tribological problems are estimated to cause as much as $5 \%$ of the reliability problems that require shutdown. Furthermore, tribology-caused shutdowns increase with the size of the power generating unit.

The ECUT survey found several tribological areas with significant energy savings potential, including gas path leakage, seals, and bearings on both the main turbine generator and on the various accessories. Different forms of bearing and lubricant problems (contaminated oils, pump problems, etc.) and vibrations are the leading causes of the plant shutdowns.

Figure ES.4 sumarizes potential savings from improving tribological problems in the electric utilities. For accessories, the major concern is sealing problems with feedwater pumps. Friction and wear are implicated in much of the seal and bearing losses. The major problems identified in this study will require research on lubrication theory and advanced materiais and coatings developments.

\section{CURRENT U.S. GOVERNMENT PROGRAMS}

The second part of ECUT's information collecting efforts involved identifying tribology R\&D currently being sponsored or conducted by the U.S. Government. This information was needed to avoid duplicating existing research and to locate those areas that need more research support. The Peterson study identified 215 current projects sponsored by 21 different government organizations. The study classified these projects by subject, objective, energy conservation relevance, type of research, phenomena and variables being investigated, materials, and applications. The principal government sponsors include the Department of Defense (DOD), the National Aeronautics and Space Admi nistration (NASA), National Science Foundation (NSF), National Bureau of Standards (NBS), and DOE.

The study located these tribolagy projects initially by using information from literature searches. Data bases used included the Smithsonian Science Information Exchange. the Defense Technical Information Center's Research and Technology Work Unit Information System, and the Materials Science Abstracts of the National Technical Information Service (NTIS). The study located a

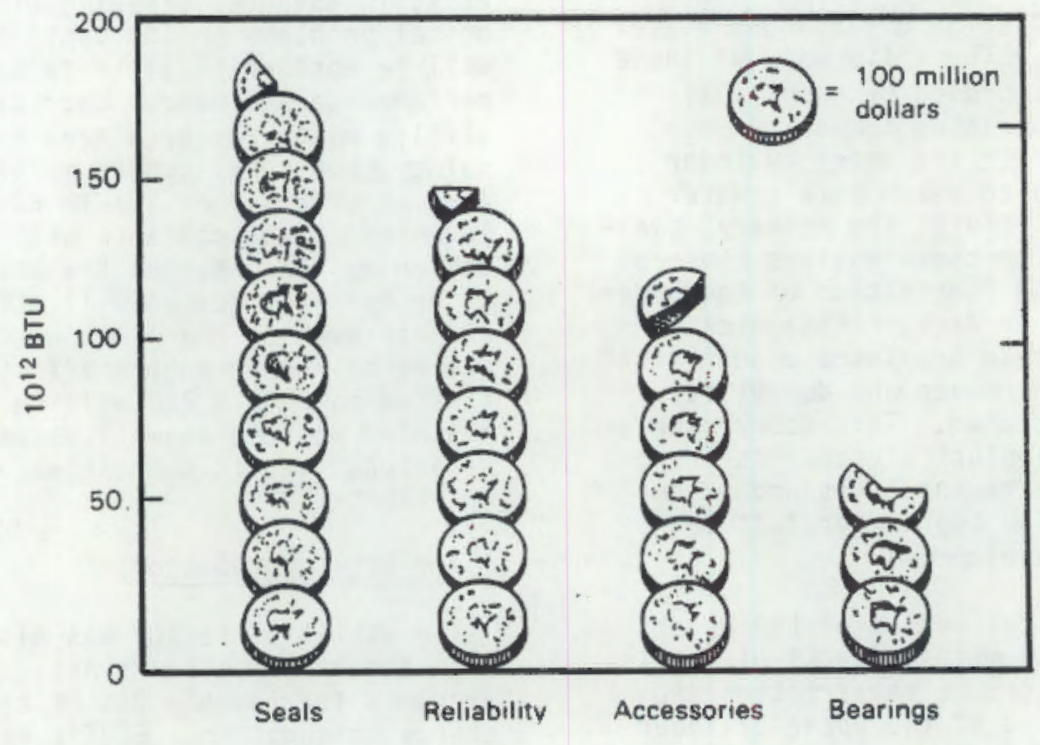

FIGURE ES.4. Potential Energy Savings for the Utilities (Based on estimates of installed capacity in 1983 and on an energy cost of $\$ 30$ per barrel.) 
total of 640 government-sponsored projects covering the fiscal years 1978-1983. These organizations were then contacted by mail, followed by visits and/or phone discussion. Of the original 640 projects, 215 were found to be current. A detailed description of each project is included in the report.

According to this study, unt1l several years ago tribology research emphasized component development, fluid film and elastohydrodynamic lubrication, and concentrated contacts. Since then the emphasis has shifted dramatically, and research efforts now concentrate on lubricants, materials and coatings, and friction and wear mechanisins. There is still considerable interest in rolling contact bearings and seals, as well as in early failure detection in maintenance technology.

The study also concluded that most current tribology research is related to $D O D$ objectives of longer life, low maintenance/ failure-free machinery, and the basic understanding of friction, wear, materials, and coatings. High-temperature lubrication also continues to be a major objective in tribology research; the effects of new materials and solid lubricants on current temperature limitations are also being studied. Coatings are receiving the most attention in general materials development. Figure ES.5 shows a breakdown of the materials considered in the 215 projects.

The author also concluded that current programs generally do not emphasize energy or materials conservation. Design predictability and composite materials are other areas that are receiving little attention. Finally, the study concluded that current
U.S. Government high-temperature lubrication work is the most applicable to energy conservation goals.

INDUSTRY PERCEPTIONS OF GENERIC RESEARCH NEEDS IN TRIBOLOGY

Because transferring information to industries is a major part of the ECUT program, ECUT conducted a survey of industry perspectives on tribology R $8 D$ needs. This survey, conducted by Sibley and Zlotnick, involved interviewing industry contacts to discover what research results are needed.

The authors held in-depth discussions with engineers and managers from 27 companies. These companies were chosen by defining different tribological categories (such as transportation, power plants, seals, gears, aerospace, etc.). At least one company was then selected for each category, and two or three were chosen for categories that are particularly important to the ECUT program. The purpose of this study was not to produce statistically significant findings, but rather to represent many different viewpoints and a variety of interests.

The authors' main emphasis was on determining the engineering limitations imposed by tribology considerations. They also tried to determine the type and funding level of current generic tribology R\&D in each company, although only pon-proprietary information was available. (a)

Based on the levels of generic tribology $R \& D$ in the 27 individual companies, the authors then estimated total tribology R\&D in each industrial segment. Although this approach is obviously limited, reasonably

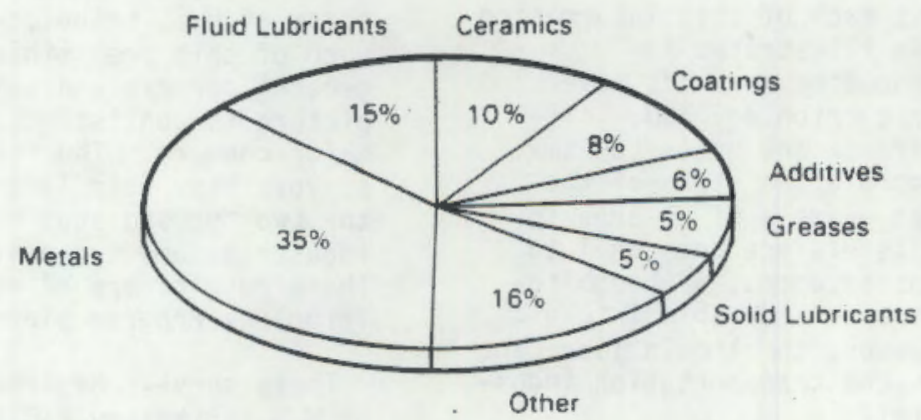

FIGURE ES.5. Materials Under Consideration in the 215 Current Government-Sponsored Tribology Projects

(a) "Generic" R\&D in this case is basic research that is not directed toward a specific end use or product. 
TABLE ES.3. Estimate of Generic Tribology R\&D and Total R\&D Budget for Representative Industries (In \$M)

\begin{tabular}{|c|c|c|c|}
\hline Classification & Company & $\begin{array}{l}\text { Total } \\
\text { R\&D (a) } \\
\end{array}$ & $\begin{array}{c}\text { Generic } \\
\text { Tribology R\&D (b) } \\
\end{array}$ \\
\hline Liquid Lubricants & Mobil & 188 & 1 \\
\hline Transportation & Ford & 1764 & 1 \\
\hline Aerospace & Pratt \& Whitney & 835 & 0 \\
\hline Powerplants & Caterpillar & 234 & 0 \\
\hline Seals & Crane & 10 & $<1$ \\
\hline Rolling Elements & TRW & 109 & $>0$ \\
\hline Gears & Eaton & 100 & $>0$ \\
\hline Sliding Bearings & Tribon & 0 & $>0$ \\
\hline Filters & Pall & 7 & 0 \\
\hline Small Mechanical & Xerox & 565 & $>0$ \\
\hline Ceramics & Norton & 26 & $<1$ \\
\hline Coatings & Union Carbide & 240 & $<1$ \\
\hline Forming & Bethlehem & 46 & $\leq 1$ \\
\hline & & 4124 & 6 \\
\hline
\end{tabular}

(a) From the report to the Securities and Exchange Commission for 1982. (Source: "Busi ness Week," June 20, 1983.)

(b) Based on discussions with research staff and referring to only company-funded generic tribology R \&D.

accurate estimates were developed of the amounts of generic tribology $R \& D$ being conducted in each of the industrial segments. The results for the individual companies are sumarized in Table ES.3.

These authors concluded that industry funds only a very limited amount of generic tribology research. Some 'hidden' generic R\&D is incorporated into the companies' design manuals, but much of this information is proprietary. As illustrated in

Table ES.3, some industry segments have little or no generic tribology R\&D. Tribology research efforts are aften too small to be likely to improve the state-of-theart; ceramics is an example of an area in which the funding levels are too small to promote significant advances, although industry has expressed considerable interest in this area. However, the liquid lubricant research budget in the transportation industries is substantial.

The industry representatives expressed interest in the ECUT Tribology Program, and also in obtaining a fundamental physical understanding of tribological mechanisms. The industry contacts also requested more effective presentations of research results, especially results in a form that design and development engineers could readily use.
Another industry concern involved developing more realistic laboratory tests and more rational performance standards.

\section{CONCLUSIONS}

The six ECUT surveys sumarized here were conducted to provide an overview of the major tribological sinks and the current state of U.S. tribology research. Although much of this preliminary ECUT work involved general surveys and samplings, the overall picture is consistent and reveals areas of major concern. The findings in the general surveys have been largely substantiated by the two focused studies on metalworking industries and the advanced diesel engine. These results are being used to support ECUT Tribology Program planning.

These surveys describe the current status of U.S. tribology R\&D in 1984; the findings will be updated as necessary. Much of the information is necessarily somewhat speculative and theoretical, and many of the general findings have not yet been fully corroborated. This is due in part to the lack of previous research; improving this initial information should be an important goal of current research. In particular, identifying tribological mechanisms should 
be emphasized in order to define specific research projects. Further discussion with industry representatives is also needed.

The five key results from these ECUT studies are listed below:

1. Advanced tribo-materials, coatings, and lubricants must be developed to further improve energy efficiency. Although tribological improvements can be made with the current technology, new and innovative materials and designs (such as the advanced diesel engine) are neeced to significantly increase energy efficiency.

2. Tribological mechanisms that shorten equipment life and cause excessive downtime and repair should be identified and studied. Initial research shows that these indt rect energy losses from material wear are often greater than the di rect energy losses from friction. In addition to the energy conservation impacts, reducing these losses could also significantiy improve industrial productivity.

3. Generic tribological research will affect all three major sectors, since similar tribological mechanisms are fourd in many different processes. Altrough the transportation sector has the largest tribological energy loss and the greatest potential for energy savings, there is significant energy savings potential in ail sectors. Thus -estarch results must be effectively irarsferred to all sectors.

4. Mearingful perfomance tests and standarcs must be developed so that new designs and products can be accurately evaluated. Laboratory tests that accurate-iy reflect real-world conditions are badly needed. Total system testing is lital, since tribological energy lasses are often caused by complex interactions between all the camponents of a system.
5. Continuing communication with industry is critical to ensure that industry research needs are addressed and that the results are adequately transferred.

These results supoorted the development of the ECUT Tribology Program plan for 1985. The research program is divided into two parts. The Mechanisms component includes such areas as advanced tribo-materials R\&D, identifying and characterizing tribological mechanisms, and developing performance test requi rements. Projects in this area include developing new tribological materials, and modeling and experimental efforts to determine physical and chemical interactions and processes in tribological systems. Liquid and soitd lubricants, tribological coatings and surface modifications, and ceramic and cermet materials are specific topics to be considered. The Mechanisms area also inciudes efforts to develop novel characterization and testing procedures and diagnostic tools and equipment to assess the performance of tribological systems.

The second part of the research program, Design, includes such topics as design and reliability modeling of components, systems, and system assemblies. Industry is di rectly involved in these projects. The Design area will also establish a data center to gather and disseminate information on tribology. These projects concentrate on generic tribology R \&D, including energy losses from materíal wear.

Clearly, tribology research can have a major impact on energy use and conservation in the U.S. Much of the needed research identified in these studies is innovative and high-risk, which makes tribology a vital and appropriate area for ECUT support. Thus the ECUT Tribology Program, with industry participation and cooperation, wi il continue its efforts to reduce the enormous energy losses caused by friction and wear. 



\section{CONTENTS}

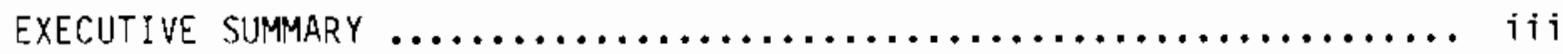

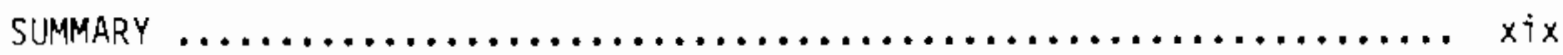

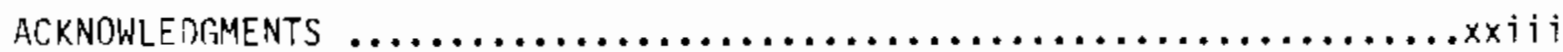

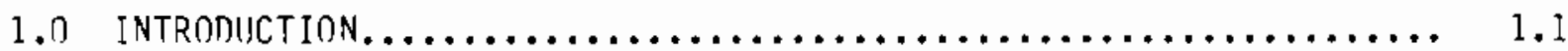

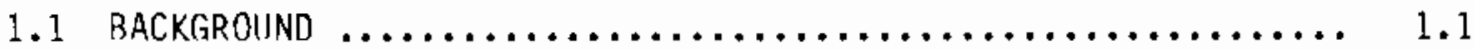

1.1.1 The ECUT Program $\ldots \ldots \ldots \ldots \ldots \ldots \ldots \ldots \ldots \ldots \ldots, 1.1$

1.1.2 ECUT Tribology R\&D Planning $\ldots \ldots \ldots \ldots \ldots \ldots \ldots \ldots, 1.2$

1.2 APPROACH $\ldots \ldots \ldots \ldots \ldots \ldots \ldots \ldots \ldots \ldots \ldots \ldots \ldots \ldots \ldots \ldots \ldots \ldots \ldots \ldots, 1.2$

1.3 ChAPTFR CONTENTS................................... 1.3

2.0 THE TRIBOLOGICAL. IMPACT OF SUIRFACE MODIFICATION TECHNOLOFIES $\ldots . .2 .1$

2.1 SIJRFACE MODIFICATION TECHNOLOGIES AND RELATED R\&I ISSIJES $\ldots \quad 2.1$

2.1.1 Ion Implantation $\ldots \ldots \ldots \ldots \ldots \ldots \ldots \ldots \ldots \ldots, 2.1$

2.1.2 Coating Deposition $\ldots \ldots \ldots \ldots \ldots \ldots \ldots \ldots \ldots \ldots, 2.3$

2.1.3 Laser and Electron Beam Surface Modification ........ 2.5

2.1.4 Electron Beam Surface Modification $\ldots \ldots \ldots \ldots \ldots . . .2 .7$

2.2. THE TRIBOLOGICAL IMPROVEMENT ACHIEVEN WITH SURFACE

MODIFICATIDN TECHNOLDGIES $\ldots \ldots \ldots \ldots \ldots \ldots \ldots \ldots \ldots \ldots \ldots \ldots \ldots \ldots \ldots, 2.7$

2.2.1 Wear Reduction in Metalforming $\ldots \ldots \ldots \ldots \ldots \ldots \ldots .2 .7$

2.2.2 Hear Reduction in Metalcutting $\ldots \ldots \ldots \ldots \ldots \ldots \ldots, 2.7$

2.2.3 Friction Reduction in Metalforming .............. 2.9

2.2.4 Friction Reduction in Metalcutting .............. 2.9

REFERENCES $\ldots \ldots \ldots \ldots \ldots \ldots \ldots \ldots \ldots \ldots \ldots \ldots \ldots \ldots \ldots \ldots \ldots \ldots \ldots \ldots \ldots \ldots \ldots, 2.11$

3.n THE METALWORKING INDUISTRIES $\ldots \ldots \ldots \ldots \ldots \ldots \ldots \ldots \ldots \ldots \ldots \ldots \ldots \ldots \ldots \ldots, 3.1$

3.1 DESCRIPTION OF THE METALWORKING INDHISTRIES $\ldots \ldots \ldots \ldots \ldots \ldots, 3.1$

3.1.1 Nature of the Metalworking Industries $\ldots \ldots \ldots \ldots \ldots .3 .1$ 
3.1.2 The Economic Importance of the Metalworking Industries $\ldots \ldots \ldots \ldots \ldots \ldots \ldots \ldots \ldots \ldots \ldots \ldots, \quad 3.2$

3.1.3 Energy Consumption in the Metalworking Industries ... 3.2

3.2 MACHINERY AND EOUIPMENT IN THE METALWORKING INDUSTRIES $\ldots . .3 .2$

3.2.1 Metalcutting Machines and Accessories ............ 3.6

3.2.2 Metalforming Machines ......................... 3.10

REFERENCES

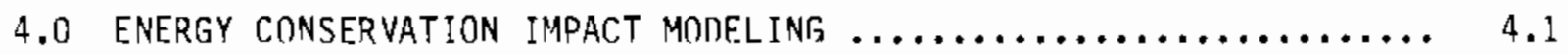

4.1 ANALYSIS OF ENERTYY USE IN METALWORKING $\ldots \ldots \ldots \ldots \ldots \ldots \ldots, 4.1$

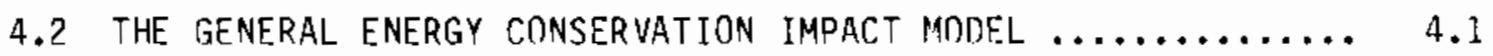

4.2.1 Machine Energy Consumption $\ldots \ldots \ldots \ldots \ldots \ldots \ldots \ldots, 4.3$

4.2.? Frictional Losses at Drive System $z \ldots \ldots \ldots \ldots \ldots . .4 .6$

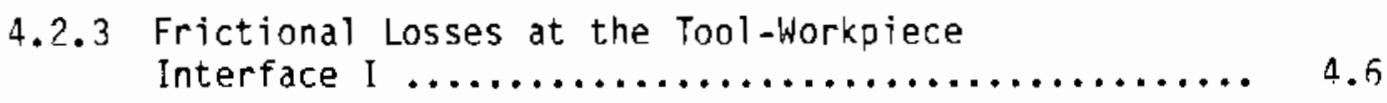

4.?.4 Other Components of the Model .................. 4.14

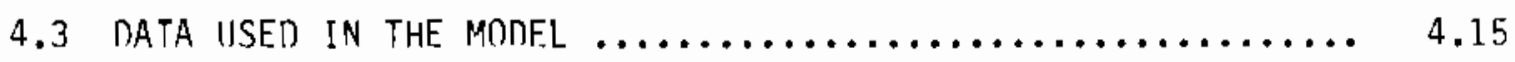

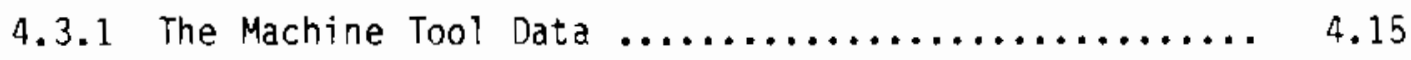

4.3.2 The Main Spindle Nrive Horsepower Rating .......... 4.16

4.3.3 Coefficient of Friction Data for Metalforming Machines ..................................... 4.16

4.4 METALWORKING ALLOY CONSUMPTION DATA $\ldots \ldots \ldots \ldots \ldots \ldots \ldots \ldots, 4.20$

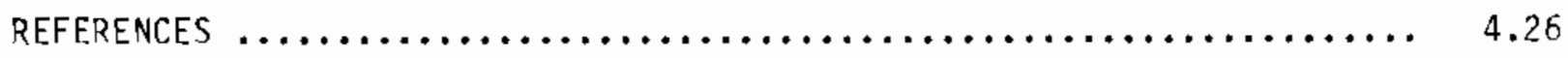

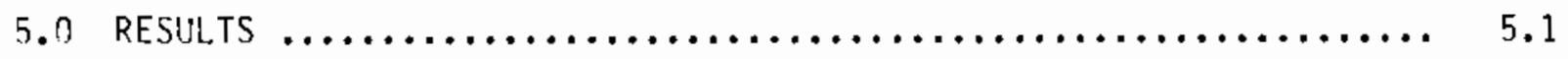

5.1 EFFECTS OF SURFACE MODIFICATION TECHNOLOGIES

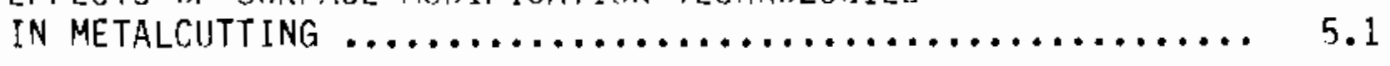

5.1.1 The Frictional Sink in Metalcutting .............. 5.1

5.1.? The Wear Sink in Metalcutting $\ldots \ldots \ldots \ldots \ldots \ldots \ldots . . .6 .1$ 
5.1.3 Energy Savings Achievable from Friction Reduction with Surface Modification Technologies ............ 5.1

5.1.4 Energy Savings Achievable from Wear Reduction with Surface Modification Technoiogies ............... 5.9

5.1.5 Metalcutting Sumary ..................... 5.9

5.2 EFFECTS OF SURFACE MODIFICATION TECHNOLOGIES

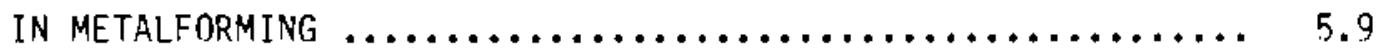

5.2.1 The Frictional Sink in Metalforming ............ 5.9

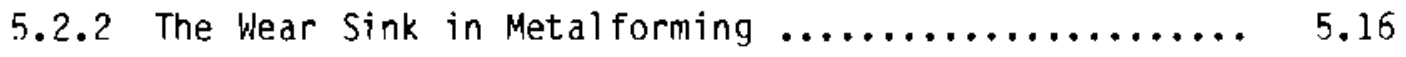

5.2.3 Energy Savings Achievable from Friction Reduction
with Surface Modification Technologies ........... 5.16

5.2.4 Energy Savings Achievable from Wear Reduction

5.2 .5 Metalforming Summary $\ldots \ldots \ldots \ldots \ldots \ldots \ldots \ldots \ldots \ldots \ldots \ldots .16$

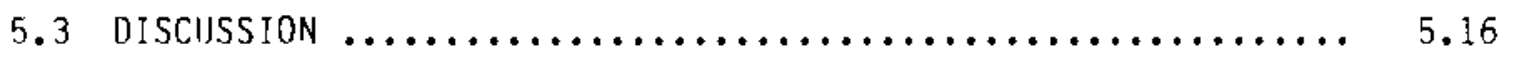

5.3 .1 Upper Bound Estimates $\ldots \ldots \ldots \ldots \ldots \ldots \ldots \ldots \ldots \ldots \ldots .6 .18$

5.3.2 Effect of Productivity Increase $\ldots \ldots \ldots \ldots \ldots \ldots \ldots . . \ldots .20$

APPENIIX A - THE METALWORKING-INTENSIVE INDUSTRIES $\ldots \ldots \ldots \ldots \ldots \ldots \ldots$ A.1

APPENDIX B - SPINDLE DRIVE HORSEPOWER OF SELECTED METALWORKING

APPENDIX C - SPINDLE DRIVE HORSEPOWER OF SELECTED MACHINE TOOLS ..... C. 
S.1 Energy Savings Estimation Model $\ldots \ldots \ldots \ldots \ldots \ldots \ldots \ldots \ldots \ldots \ldots \ldots \ldots \ldots \ldots$

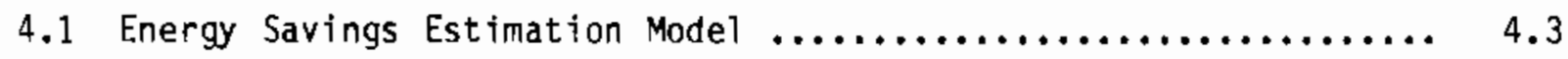

4.2 Machine Utilization in Metalcutting $\ldots \ldots \ldots \ldots \ldots \ldots \ldots \ldots . . .4 .4$

4.3 The Orthogonal Cutting Model $\ldots \ldots \ldots \ldots \ldots \ldots \ldots \ldots \ldots \ldots \ldots \ldots, 4.8$

5.1 Frictional Losses at the Drive System $\ldots \ldots \ldots \ldots \ldots \ldots \ldots \ldots . . .6 .7$

5.2 Frictionat Losses at the Toot Point .................... 5.8

5.3 Metalcutting Energy Savings Potential .................... 5.10

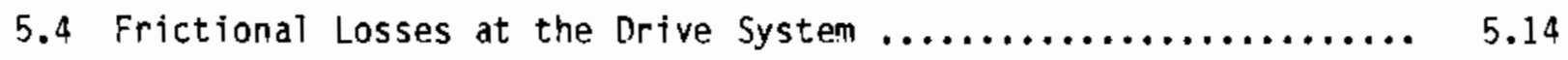

5.5 Frictional Losses at the Tool Point ..................... 5.15

5.6 Metalforming Energy Savings Potential ................... 5.17 


\section{TABLES}

S.1 Tribological Sinks in Metaiworking $\ldots \ldots \ldots \ldots \ldots \ldots \ldots \ldots \ldots \ldots \ldots+\ldots \ldots$

S.2 Energy Conservation with Surface Modification Technologies ......xxit

S.3 Dollar Values of Tribological Losses and Energy Savings Potential with Surface Modified Tools in Metalworking .................. xxi

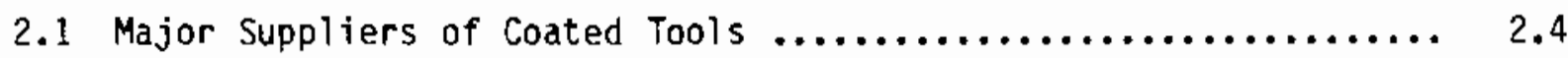

2.2 Wear Reduction in Metalforming Achieved with Nitrogen

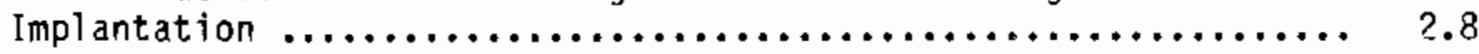

2.3 Tool Life Increase in Drilling with TiN Coated Drills ......... 2.9

3.1 Income and Employment in the Metalworking-Intensive

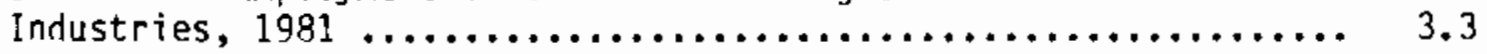

3.2 Purchased Fuel and Electricity Consumption for Heat and Power by Major Metalworking Industries, $1981 \ldots \ldots \ldots \ldots \ldots \ldots \ldots \ldots .6 .4$

3.3 Non-Metalworking Energy Uses in the Metalworking-Intensive

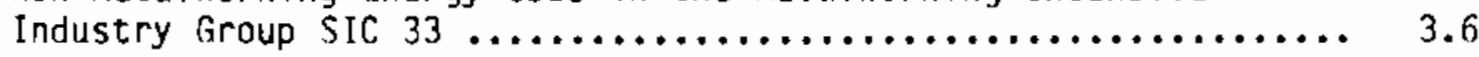

3.4 Characterization of 18 Types of Presses $\ldots \ldots \ldots \ldots \ldots \ldots \ldots \ldots \ldots . .14$

4.1 Impact of Friction and Wear Reduction on Energy Use in

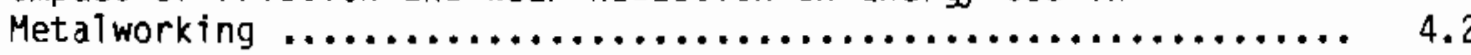

4.2 Calculate Values for Cutting Efficiency $u$ as a Function of

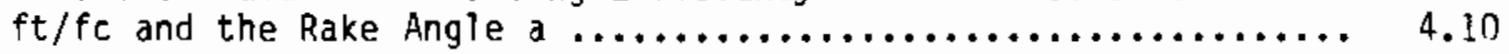

4.3 Metalcutting Machine Tools Considered in this Study ........... 4.17

4.4 Metalforming Machine Tools Considered in this Study ........... 4.18

4.5 Cutting Conditions and Derived Motor Horsepower ............. 4.19

4.6 Materials Averaged Motor Horsepower, by Operation and Industry .. 4.20

4.7 Typical Metalworking Coefficients $\ldots \ldots \ldots \ldots \ldots \ldots \ldots \ldots \ldots \ldots \ldots . \ldots \ldots .21$

4.8 Alloy Consumption by Metalworking Industries, $1977 \ldots \ldots \ldots \ldots \ldots .4 .22$

4.9 Industrial Metalworking of Major Alloys, by Percent, I977 ...... 4.23

4.10 Shipment values of Metal forming Accessories $\ldots \ldots \ldots \ldots \ldots \ldots \ldots . . \ldots \ldots .24$

4.11 Estimated Alloy Consumption for Metalworking Tools ........... 4.25 
5.1 Metalcutting Energy Savings Model Inputs and Results ......... 5.2

5.2 Metalforming Energy Savings Estimation Model, Frictional

Sink Consumption ............................... 5.11

5.3 Tribological Losses and Energy Savings Potential with

Surface Modified Tools in Metalworking ................... 5.18

5.4 Dollar Values of Tribological Losses and Energy Savings

Potential with Surface Modified Tools in Metalworking .......... 5.18

5.5 Upper Bound Estimates of Tribological Losses and Energy Savings

Potential with Surface Modified Tools in Metalworking .......... 5.19 
PURPOSE OF THE STUDY

This report assesses the energy conservation impact of surface modification technologies on the metalworking industries. It was prepared for the Energy Conversion and Utilization Technologies (ECUT) Division of the Departnent of Energy's Energy Systems Research Office. This report is part of the background data for ECUT's tribology research plan.

SCOPE OF THE STUDY

The energy conservation impact of surface modification technologies on the metalworking industries is assessed by estimating their friction and wear tribological sinks and the subsequent reduction in these sinks when surface modified tools are used.

Surface Modification Technologies Considered in This Study

Surface modification technologies are thermal, chemical, or mechanical treatments (or a combination thereof) that can impart tribologically superior properties to the surface of a material without changing its bulk properties.

This study considers only advanced surface modification technologies, namely, ion implantation, coatings, and laser and electron beam surface nodifications.

The Metalworking Industries and Metalworking Machines Considered in This Study

AlI manufacturing industries that cut or form metals are considered. Metalworking and metalcutting associated with primary metals processing are not included, however, because they have been analyzed in another study. (a)

The metaiforming machines considered are punches, presses, and forges. The metalcutting machines are turning, drilling, milling, broaching, and sawing machines. The study considered 326,587 metalfoming machines, or 67 percent of all metalforming machines in the United States; it considered 1,215,780 metal-

(a) Imhoff, C. H., et al. 1985. A Review of Tribological Sinks in Six Major Industries. PNL -5535 , Pacific Northwest Laboratory, Richland, Washington. 
cutting machines, or 71 percent of all metalcutting machines in the country. 0verall, the study considered 70 percent of all metalworking machines in the United States.

METHODOLOGY

The energy savings model developed to estimate the friction and wear tribological sink is shown in Figure $\mathrm{S.1}$.

The frictional tribological sink is estimated as the sum of frictional losses at the motor drive system and at the tool-workpiece interface. The wear tribological sink is the embodied energy of all metalworking tools consumed and discarded in one year. The energy savings due to surface modification are equal to the tribological sink adjusted downward to take into account increased tool life and the reduction in friction due to surface modification. Such downward adjustments are made using known functional relations between the coefficient of friction and the work done to overcome friction during metal working.

RESULTS

Tribological Sinks in Metalworking

Estimates for the tribological sinks in metalworking are shown in Table S.1.

The drive sink is defined as frictional losses at the drive system of the metalworking machines considered. The drive sink for a given machine is calculated as 20 percent of the total power output of its main drive motor.

The tool sink is defined as frictional losses at the tool-workpiece interface during metalworking. For metalcutting, the tool sink is calculated as 50 percent of the power delivered at the tool joint. For metalforming, the sink is calculated as 10 percent of the main drive motor output that is available to the metalforming process. The percentage values used (50 percent and 10 percent) are based on an analysis of the functional relations between the work done to overcome friction and the coefficient of friction in representative metalworking operations. 


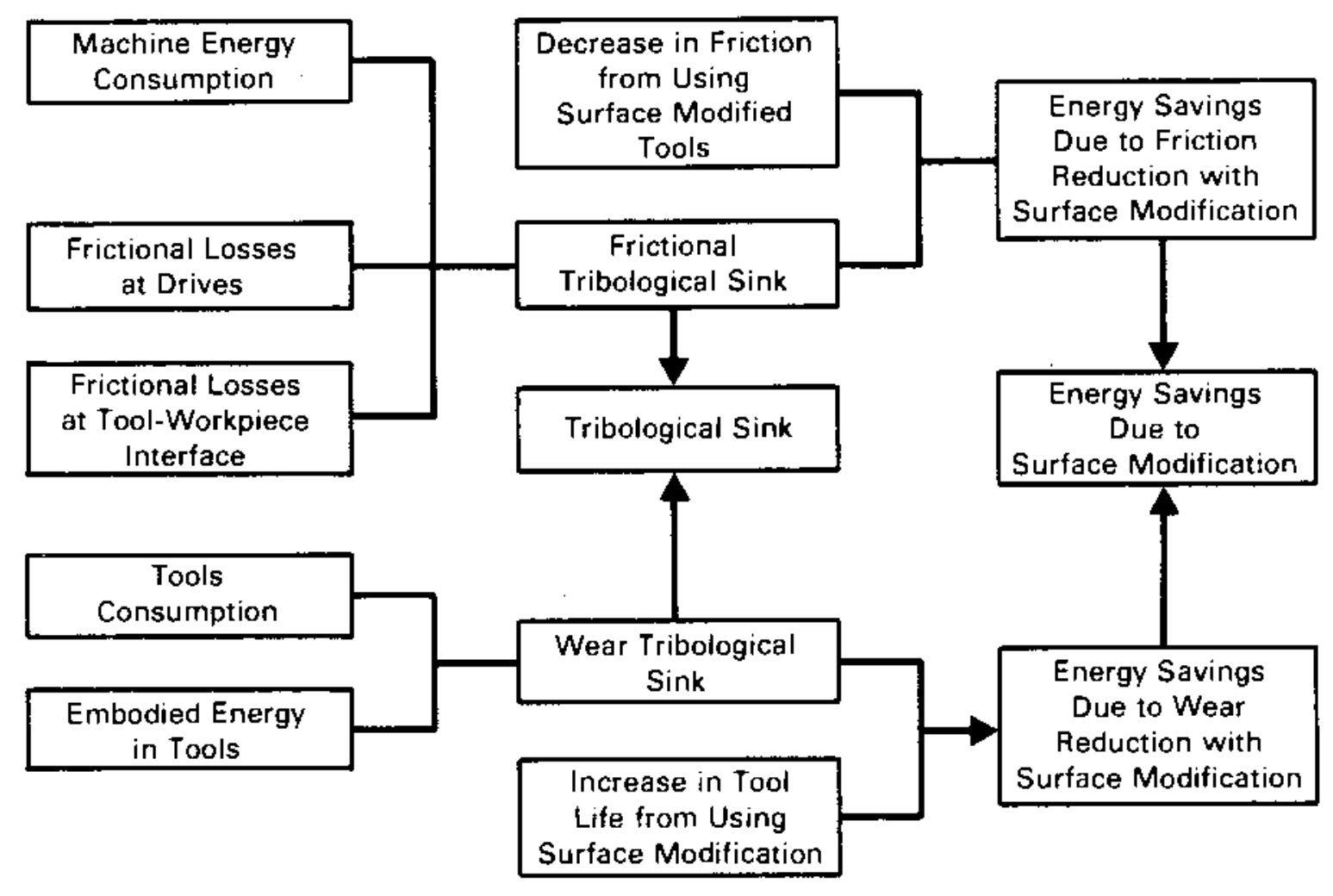

FIGURE S.1. Energy Savings Estimation Model

IABLE S.1. Tribological Sinks in Metalworking (billion Btu/year)

\begin{tabular}{|c|c|c|c|c|}
\hline Operation & $\frac{\text { Frictional }}{\text { Drive }}$ & Sink & $\begin{array}{l}\text { Wear } \\
\text { Sink }\end{array}$ & Tota? \\
\hline Metalcutting & 2,490 & 3,320 & 2,323 & 8,133 \\
\hline Metalforming & 10,400 & 4,000 & 5,370 & 19,770 \\
\hline Total & 12,980 & 7,320 & 7,693 & 27,903 \\
\hline
\end{tabular}

The wear sink is defined as the energy embodied in the steels that are used to manufacture metalworking tools, e.g., cutting tools, punches, and dies. The wear sink is calculated using estimated tonnages of the steels used to manufacture metalworking tools and an embodied energy figure of 19.2 million Btu/ton of steel. 
ENERGY CONSERVATION IMPACT OF SIJRFACE MODIFICATION TECHNOLOGIES

Estimates of the energy savings achievable when surface modified tools are used in metalworking are shown in Table S.2.

Assuming an electricity purchase price of $\$ 12 /$ million Btu, the dollar costs of tribological losses total $\$ 335 \mathrm{million} /$ year; at the same time, the savings with use of surface modified tools would be $\$ 88$ million/year (see Table 5.3). Note that the dollar losses and savings are averaged over the whole country without regard to regional variations in energy costs.

TABLE S.2. Energy Conservation with Surface Modification Technologies (billion Btu/year)

\begin{tabular}{|c|c|c|c|c|}
\hline \multirow[b]{2}{*}{ Operation } & \multicolumn{2}{|c|}{$\begin{array}{l}\text { Reduction in the } \\
\text { Friction Sink }\end{array}$} & \multirow{2}{*}{$\begin{array}{l}\text { Reduction in } \\
\text { the Wear Sink }\end{array}$} & \multirow[b]{2}{*}{ Tota 1} \\
\hline & Drive & To01 & & \\
\hline Metalcutting & 0 & $739(22 \%(\mathrm{a}))$ & $1,936 \quad(83 \%)$ & $2,675(53 \%)$ \\
\hline Meta1 forming & 0 & $1,100(25)$ & $3,580 \quad(67)$ & $4,680 \quad(24)$ \\
\hline Tota 1 & 0 & $1,839(25)$ & $5,536 \quad(72)$ & $7,355 \quad(26)$ \\
\hline
\end{tabular}

(a) Percent of the sink.

TABLE S.3. Dollar Values of Tribological Losses and Energy Savings Potential with Surface Modified Tools in Metalworking (million dollars/year)

\begin{tabular}{|c|c|c|c|c|c|c|}
\hline \multicolumn{3}{|c|}{ Operation } & $\frac{\text { Frictional }}{\text { Drive }}$ & $\frac{\text { Sink }}{\text { Tool }}$ & $\begin{array}{l}\text { Wear } \\
\text { Sink }\end{array}$ & Total \\
\hline \multirow[t]{2}{*}{ Metalcutting: } & Losses & & 29.9 & 39.8 & 27.8 & 107.5 \\
\hline & Saving & & 0 & 8.9 & $23 . ?$ & 32.1 \\
\hline \multirow[t]{2}{*}{ Metal forming: } & Losses & & 124.8 & 48.0 & 64.4 & 237.2 \\
\hline & Saving & & 0 & 13.2 & 43.0 & 56.2 \\
\hline \multirow[t]{2}{*}{ Cutting and $F$} & ming: & Losses & 154.7 & 87.8 & 92.2 & 334.7 \\
\hline & & Savings & - & 22.1 & 66.2 & 88.3 \\
\hline
\end{tabular}




\section{ACKNOWLEDGMENTS}

The research staff of this project would like to thank Carl Imhoff, PNL. Technical Monitor for this project, for his guidance and support. We would like also to thank Sheila Mulvihill and Donna Kuick for providing editorial assistance and Judy Cable for producing the various draft reports. Finally, we extend our appreciation to John Brogan, Terry Levinson, and Manfred Kaminsky of the IJ.S. Department of Energy for their support throughout this project. 



\subsection{INTRODUCTION}

Tribology, the science of surfaces in dynamic contact, is concerned with the phenomena of wear, friction, and Tubrication. These phenomena are important to the conservation of energy. High friction reduces the energy conversion efficiencies of mechanical devices and processes; excessive wear increases the replacement rate of accessories and components, which have embodied energy costs of their own.

Modification of surfaces can reduce energy losses caused by tribological phenomena. Surfaces may he treated thermally, chemically, or mechanically -or by a combination of technologies -- to impart tribologically superior properties to the surface of a material without changing its bulk properties.

This study assesses the impacts of surface modification technologies on tribological energy losses in metalworking operations. It was sponsored by the Energy Conversion and Utilization Technologies (ECUT) Division of the Office of Energy Systems Research in the Department of Energy's Office of the Assistant Secretary for Conservation and Renewable Energy. This study was sponsored as part of the ECUT R\&D planning for the tribology component of its program.

\subsection{BACKGROUND}

\subsubsection{The ECIJT Program}

ECUT supports long-term, high-risk, generic applied research and exploratory development pertinent to energy conservation. The four major goals of ECUT are to: (a) establish the feasibility of revolutionary concepts to reduce energy consumption significantly; (b) monitor and assess the applicability of advances in basic research to energy conservation; (c) carry out exploratory development of novel or innovative concepts; and (d) expand the technology base for advanced conservation technologies. To implement these goals, ECUT has been pursuing three programs: Combustion and Thermal Sciences, Materials Science, and Tribology. The Combustion and Therma? Sciences Program sponsors R\&D activities in areas such as stratified charge combustion, diesel combustion, fluid flow in shell and tube heat exchangers, and dilute homogeneous charging. The Materials Science Program sponsors research in high-temperature, 
light-weight, and innovative building materials and theoretical and experimental research in materials design. The tribology program sponsors research in base stock oil, friction and wear of ceramics, solid lubricants, and, because tribology is new to ECUT, tribology R\&D planning.

\subsubsection{ECUT Tribology R\&D Planning}

The ECUT tribology R\&D planning process consists of identifying and quantifying the major tribological sinks, i.e., the industries, machines, or components in which energy losses through tribological phenomena are greatest; determining the tribological mechanisms operating at these sinks; and identifying the more promising tribological control technologies.

\subsection{APPRDACH}

The energy savings attributable to surface modification technologies are defined as equalling the tribological sink adjusted downward to account for two surface modification-induced effects: the decrease in the coefficient of friction at the tool-workpiece interface and the increase in tool life. In metalworking, the tribological sink is defined conventionally as the sum of the energies lost directly through friction and indirectly through wear.

In implementing the above approach, DHR considered metalworking machines in groups rather than by individual machine type. Thus, metalcutting machines are classified as turning (e.g., turning and boring machines and machining centers), milling (e.g., milling and gear cutting machines), drilling (e.g., drilling and tapping machines), and sawing (e.g., cutoff and sawing machines, hacksaw and band sawing machines). Similarly, metalforming machines are classified as punching and shearing, bending and forming, and presses and forges.

For the estimates of energy consumption by each group of machines, conditions as realistic as passible are used. For example, for metalcutting machines, the total working time, the machining parameters (speed, feed, depth of cut) are chosen according to known standard conditions. In the same manner, tribological improvements attributable to surface modification technologies are taken from actual experimental or production setting data. 
The computational facility is a spreadsheet program, specifically, the lotus 1-2-3 software. It is ideal for repetitive calculations of the type performed in this study.

\subsection{CHAPTER CONTENTS}

Chapter 2 briefly reviews R\&D and comercial activities in surface modification technologies, particularly the tribological improvements attributable to surface modified tools. Chapter 3 defines and describes the metalworking industries and operations considered in this study. Chapter 4 details the methodology used to estimate the metalworking tribological sinks and the energy savings attributable to the use of surface modified toois. Chapter 5 presents the results of the model implementation developed in Chapter 4 , using the data compiled in Chapters 2 and 3. 



\subsection{THE TRIBOLOGICAL IMPACT OF SURFACE MODIFICATION TECHNOLOGIES}

Surface modification technologies are thermal, chemical, or mechanical treatments (or any combination thereof) that can impart desirable properties to the surface of a material without affecting its bulk properties. Although heat treatment is used to build a hard, wear-resistant outer layer on a component, it is not included here because this study is focusing on innovative approaches. The surface modification technologies included are ion implantation, laser surface hardening, electron beam surface hardening, and coating deposition. Strictly speaking, coating is not a true surface modification technology. However, because coating is the principal commercial technique used to produce a very thin and tribologically superior surface on metalworking tools, coating deposition is also considered.

\subsection{SURFACE MONIFICATION TECHNOLOGIES AND RELATED R\&D ISSUES}

\subsubsection{Ion Implantation}

\subsubsection{Technology Status}

Ion implantation involves the in-vacuo acceleration of ion species (such as the ions of $\mathrm{Ti}, \mathrm{Ta}, \mathrm{Cr}, \mathrm{Ni}, \mathrm{N}, \mathrm{Al}$ ) under a high voltage (typically up to $? 00 \mathrm{kV}$ ) onto the surface of a target workpiece. As these ions impact and penetrate the: surface, they displace atoms from their equilibrium position, generate cascades of defects and compositional changes to a depth of 200 nanometers $(\mathrm{nm})$, and thus create a surface layer that differs sharply from the bulk in terms of microstructure and properties.

The microstructures created by ion implantation are complex: most are formed through nonequilibrium transformation processes in a crystal lattice that has a very high defect density. Observed microstructures include supersaturated substitutional solutions, metastable crystalline and amorphous phases, complex defect clusters, and very fine precipitates. Properties that are enhanced by ion implantation include hardness, toughness, ductility, and resistance to friction, wear, adhesion, corrosion, fatigue, and oxidation (Refs. 1, 2). 
Ion implantation is available commercially in the United States as a tribological surface treatment for metalworking tools by Zymet Incorporated, of Danvers, Massachusetts (Ref. 3). The Navy recently contracted with Spire Corporation of Bedford, Massachusetts, to investigate the benefits of ion implantation on ball bearing components and stamping and punching tools (Ref. 4). In the United Kingdom, Harwell has conducted case studies of the industrial application of nitrogen ion implantation in more than 100 companies since 1978 (Ref. 5).

\subsubsection{Research Opportunities}

Basic ion implantation research in the Inited States is supported by private industry and the government. The latter include the Naval Research Laboratory at the University of Virginia, the Nationa? Science Foundation at the University of Connecticut, and the Department of Energy at Oak Ridge National laboratory (Ref. 6).

Basic research opportunities in ion implantation are numerous. Although the structure and properties of the ion implanted layers have been well characterized and to some extent correlated with implantation parameters, not all the microstructures found can be explained. Specifically, fine scale microstructural features such as the presence of amorphous and amorphous-to-crystalline transition phases (Ref. 7), the dislocation density, and precipitate size have not been consistently predicted (Ref. 8). Because many of the microstructural transformations in the ion implanted layer are nonequilibrium phenomena, research in nonequilibrium transformations as they relate to ion implantation will be needed. From a tribological perspective, any research that attempts to relate nonequilibrium microstructures to friction and wear reduction would be extremely relevant. Although such work on $\mathrm{Ti}, \mathrm{C}, \mathrm{N}$, and Ta implanted steels has been initiated at the Naval Research Laboratory under the direction of Singer, much remains to be done. For example, understanding the nature and role of amorphous phases in the friction reduction mechanisms that operate in ion implanted layers is important because these phases must be present to lower the coefficient of friction (Ref. 1).

Other research opportunities also exist. Thus, ways to increase the penetration depth other than increasing the ion implantation beam energy are needed 
because, at high beam energy, the inward diffusion of the implanted ion species is inhibited by the beam heating effects and radiation damages phenomena.

Similarly, ways must be found to maximize multi-beam sequential ion implantation in order to prevent impacting ions' ejecting previously embedded ones out of the sample surface (Ref. 7).

\subsubsection{Coating Deposition}

\subsubsection{Technology Status}

Hard, wear-resistant coating compounds such as $\mathrm{Al}_{2} \mathrm{O}_{3}, \mathrm{MfN}, \mathrm{TiC}$, and TiN are deposited on a metalworking tools in a variety of ways. In chemical vapor deposition (CVD), a carrier gas (such as $\mathrm{TiCl}_{4}$ ) is reacted with a reactive gas ( such as $\mathrm{N}_{2}$ ) in an evacuated and heated chamber to fom a compound ( $\mathrm{TiN}$, in this case) on the workpiece. CVD is carried out at high temperatures, 1750$1950^{\circ} \mathrm{F}$, so that reheat treatment for most tool materials would be needed. In basic physical vapor deposition (PVD), a high voltage existing between the workpiece (which acts as the anode) and the target (which acts as the cathode) causes the target atoms to be ionized and accelerated toward the workpiece, where they deposit to fom the desired coating. Variations of the basic pvo process include reactive sputtering, in which a gaseous reaction similar to the one found in CVD takes place to form the coating compound; reaction ion plating, in which the target material is ionized in the presence of a reactive gas to form the ion species on the workpiece; and arc-evaporation, in which an arc is used to localize the CVD process over a small area. PVD is carried out at 300-900\%: so that reheat treatment of the samples is not usually necessary.

The deposition of a hard, wear-resistant coating on metalworking tools is a big industry. Most small cutting tools and many forming dies and punches are now commercially available with a TiN coating (see Table 2.1). Many tool suppliers do the coating themselves or contract with a coating firm to have it done. Companies that supply CVD coating systems are the Sylvester Company (Beachwood, Ohio), which uses a process developed by Bennex (Switzerland); Ti-Coating Incorporated (Mt. Clemens, Michigan); and Scientific Coating Incorporated (Troy, Michigan). The PVD system suppliers are Balzer High-Vacuum Corporation (Hudson, New Hampshire), Multi-Arc Vacuum Systems Incorporated 
TABLE 2.1. Major Suppliers of Coated Tools (Ref. 9)

\begin{tabular}{|c|c|c|}
\hline Company & Location & Major Coated Product \\
\hline American Broach & Ann Arbor, Michigan & Broaches \\
\hline American Intertool & Elk Grove Village, Michigan & End $\mathrm{Mill}$ \\
\hline American Pfauter & Elk Grove Village, Michigan & Hobs \\
\hline arber Colman & ockford, Illinois & $\begin{array}{l}\text { Hobs, Cutters of A11 } \\
\text { Types }\end{array}$ \\
\hline Cosa Corporation & Montvale, New Jersey & Hobs \\
\hline netroit Tap and Tool & Warren, Michigan & $\begin{array}{l}\text { Tap, Thread Mill, } \\
\text { Thread Gages }\end{array}$ \\
\hline $\begin{array}{l}\text { DoAl1 Company } \\
\text { Blades }\end{array}$ & Des Plaines, Illinois & End Mill, Band Saw \\
\hline $\begin{array}{l}\text { Ekstrom, Carlson and Company } \\
\text { Fellows Corporation }\end{array}$ & $\begin{array}{l}\text { Rockford, Illinois } \\
\text { Springfield, Virginia }\end{array}$ & $\begin{array}{l}\text { Router Bits } \\
\text { Gear Shaper Cutters }\end{array}$ \\
\hline General Broaches & Detroit, Michigan & Broaches \\
\hline Guhring Broaches & Detroit, Michigan & Twist Drill, Reamers \\
\hline Nachi America & Carlstadt, New Jersey & Hob, End Mil1s \\
\hline $\begin{array}{l}\text { Onsrud Cutter } \\
\text { Manufacturing Company }\end{array}$ & Libertyville, Illinois & $\begin{array}{l}\text { Milling Cutter, } \\
\text { Router Bits }\end{array}$ \\
\hline Start Cutter Company & Farmington Hills, Michigan & $\begin{array}{l}\text { Hobs, Form Tools, } \\
\text { Reamers }\end{array}$ \\
\hline $\begin{array}{l}\text { TRW Drill and End } \\
\text { Mill Division }\end{array}$ & Augusta, Georgia & $\begin{array}{l}\text { Twist Drill, End } \\
\text { Mills }\end{array}$ \\
\hline val form & Troy, Michigan & T15 Inserts \\
\hline Vermont Tap and Die Company & Lyndonville, Vermont & Taps, Drills \\
\hline Waukesha Cutting Tools & Waukesha, Wisconsin & Spade Drill Blades \\
\hline \multicolumn{3}{|c|}{$\begin{array}{l}\text { (St. Paul, Minnesota), and UTvac North America Corporation (Kennebunk, Maine } \\
\text { which represents the Ulvac Corporation of Japan (Ref. 9). } \\
\text { Government support for coating research comes from many quarters. The } \\
\text { Department of Energy sponsors research on cutting tool coatings at Argonne } \\
\text { National Laboratory, high-temperature tribological coatings on ceramics at } \\
\text { Lawrence Berkeley Laboratory, plasma-assisted low-temperature deposition of }\end{array}$} \\
\hline
\end{tabular}


cubic boron nitride and diamond-like coatings at Oak Ridge National Laboratory, and magnetron sputtering of amorphous coatings at Jet Propulsion Laboratory. The National Aeronautics and Space Administration Lewis Research Center has investigated the sputtering of silicon and hafnium nitrides on stainless steel and the morphology of plasma coating. The National Bureau of Standards (NBS) is considering the effects of coating on hardness and friction (Ref. 6).

\subsubsection{Research Opportunities}

Bas ' $C$ research needs and opportunities in tribological coatings are numerous. A major research area is the production of strong and highly adherent coatings. CVD-deposited TiN and HfN coatings generally have low adherence and fracture toughness because, at the high deposition temperatures involved, the coating microstructure is likely to consist of large grains and the cemented carbide substrates are attacked chemically (Ref. 10). Although proprietary CVD sechniques to produce very fine grained microstructures have been developed 'Ref. 11), a lower CVD process temperature to minimize subsequent heat treatment is desirable. The development of amorphous coatings is also a promising research area. However, it is being vigorously pursued by industry. In effect, two companies, Energy Conversion Devices, Inc. and Chronar, both amorphous photovoltaic cell producers, have announced plans to market metalworking :001s with friction- and wear-resistant amorphous coatings. A second major research need is to relate coating microstructure and coating-substrate interactions to friction and wear reduction mechanism studies; little work, except the NRS effort cited above, bas been done.

Two research areas have high energy conservation potential: development of low-temperature coating deposition processes and development of cubic boron nitride (CBN) coatings. A low-temperature coating process would minimize sample heat:ng and eliminate the additional heat treatment to recover the optimum bulk properties. The development of a CBN coating would maximize the benefits of coatings because $C B N$ is second only to diamond in bardness.

\subsubsection{Laser and Electron Beam Surface Modification}

\subsubsection{Technology Status}

In laser surface modification, a narrow, high-power laser beam is directed onto a metal surface where some of its energy is absorbed and converted into 
heat. As the beam is scanned across the surface, extremely rapid and localized heating and cooling of the surface occurs along the path of the beam, thus producing the laser-modified layer. The depth of the laser-modified layer depends on the power of the laser, the duration of the laser pulse or the scan rate, and the optical and thermal properties of the materials. Typical depths are 100-200 $\mathrm{nm}$. In laser surface alloying, alloying elements are introduced into the laser melted surface to produce a surface layer of an alloy that is an essentially different from the bulk.

The microstructures obtained in laser surface modification and surface alloying include dendritic and columnar dendritic structures, very fine precipitates, and metastable phases that are characteristic of rapidly solidified materials. With steels, a noteworthy feature of a laser processed surface is the formation of a metastable austenite phase that will later transform into a stable martensite phase, resulting in increased hardness and wear-resistance. This phenomenon is seen in laser processed cast iron (Ref. 12) and high speed steel saw blades (Ref. 13).

Laser surface modification is used extensively by the automotive industry to harden drive train components in order to reduce friction and wear. Government sponsors of laser surface modification research include the office of Nava? Research (ONR) and the National Science Fountation (NSF). ONR is funding research on laser CVD of TiC and laser surface alloying and cladding at the University of Illinois. NSF is supporting research on the wear behavior of laser transformed gray and ductile cast iron at Iowa State University (Ref. 6).

\subsubsection{Research Opportunities}

Research on laser surface modification is primarily concerned with relating the microstructure of the laser modified layer to the laser energy deposition parameters, e.g., the substrate material, the rate of energy deposition, beam dwell time, and heat transfer phenomena at the laser modified layer (Ref. 14). Although the laser produced surfaces are well characterized, the ability to control and allow for the formation of the desired microstructures is still lacking. From a tribological perspective, the problem of relating the microstructure of the laser modified layer to its tribological properties and the laser energy deposition conditions has not been addressed. 


\subsubsection{Electron Beam Surface Modification}

Electron beam surface modification is similar to Taser surface modification, except that an electron beam is used as the heat source and a vacuum is needed. Research needs and opportunities in electron beam surface modification are similar to those found in laser surface modification. Thus, it is not necessary to go into detail here, except to note that technology development in electron beam surface modification closely follows that of electron welding (Ref. 15).

\subsection{THE TRIBOLOGICAL IMPROVEMENT ACHIEVED WITH SURFACE MODIFICATION TECHNOLOGIES}

Reduction in friction and wear and development of a better surface finish are the direct tribological improvements achievable with surface modification technologies. Because results of laboratory friction and wear tests are generally not applicable to actual production settings and should be considered only as indicators of what can be achieved with surface modification technologies, this section concentrates on the experience of surface modified tool ssers.

\subsubsection{Wear Reduction in Metalforming}

Wear reduction is indicated indirectly by an increase in tool life or in the number of operations performed before retooling; wear can also be measured directly. Table 2.2 Tists the increased wear life and additional benefits obtained by nitrogen implantation on a variety of metalforming applications. As shown, the average tool life increase is between 200 and 600 percent. The surface finish of the formed parts is generally better (Ref. 16).

\section{2.? Wear Reduction in Metalcutting}

In drilling, the effects of TiN coatings of high-speed steel (HSS) drills have been considered by TRW's Drill and End Mill Division, (a) Vermont Tap and

(a) Personal communication with J. Bhardwag, TRW Cutting Tool Division, Augusta, Feorgia. 
TABLF 2.2. Wear Reduction in Metalforming Achieved with Nitrogen Implantation (Ref. 16)

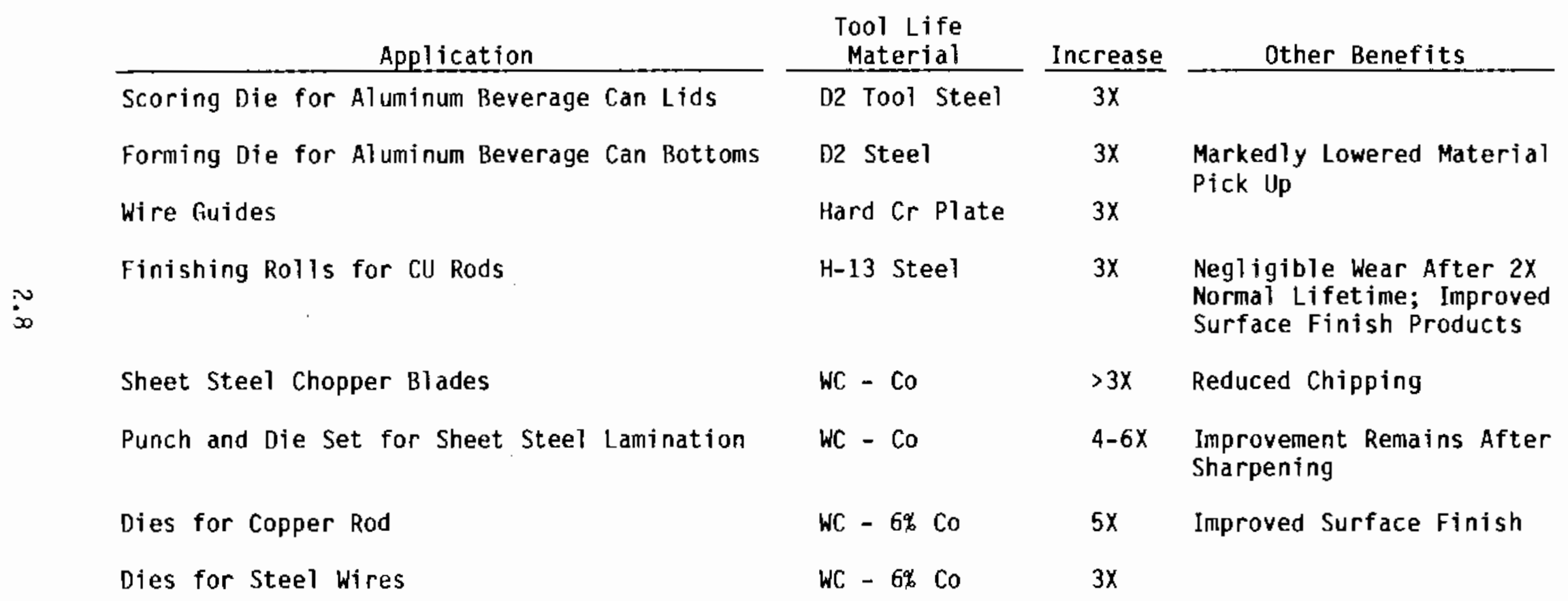


Die Company (Ref. 17), and Guhring Incorporated (Ref. 9). Conservatively, an average 600 percent increase in tool 1 ife can be expected with a TiN coating (see Table 2.3).

In milling and gear cutting, Barber-Colman Incorporated found an 800 percent increase in hob life with TiN coated tools; Fellows Corporation, a 400 percent increase (Ref. g); and the noAll Company, between 600 and 900 percent (Ref. 18). The average increase in tool life in milling and gear cutting is 600 percent.

In tapping, Vermont Tap and Die Company reported a 400 percent increase in tap life when the tap was coated with TiN (Ref. 17).

\subsubsection{Friction Reduction in Metalforming}

Actual data on a reduction in the coefficient of friction due to the use of surface modified tools in metalforming are not generally available. In a drawing experiment that compared carbide dies to sapphire $\left(\mathrm{Al}_{2} \mathrm{O}_{3}\right)$ dies, Wright noted a 7 percent decrease in the effective coefficient of friction, from 0.084 to 0.078 (Ref. 19). If sapphire dies can be taken as an approximation of the TiN or similar surface modified layers on a tool, a reduction in the coefficient of friction of the same order of magnitude should be expected from surface modified tools.

\subsubsection{Friction Reduction in Metalcutting}

Actual data on a reduction in the coefficient of friction due to the use of surface modified tools are also not available. Henderer, of Vermont Tap and Die Company (Ref. 8), noted that in drilling with TiN coated tools, torque and thrust were lowered by 34 percent and 43 percent, respectively, when compared to uncoated drills. Deller, of TRW Drill and End Mills Division (Ref. 9), also

TABLE 2.3. Tool Life Increase in Drilling with TiN Coated Drills

\begin{tabular}{|c|c|c|c|}
\hline Company & Life Increase & (Low) & (High) \\
\hline TRW Drill and End Mill Division & $7 \%$ & $(1.5 \%)$ & $(25 \%)$ \\
\hline Vermont Tap and Die Company & 6 & $(13.0)$ & $(17)$ \\
\hline Guhring Incorporated & 5 & $(12.0)$ & (9) \\
\hline
\end{tabular}


measured a 25-35 percent reduction in both feed force and spindle torque when TiN coated drills were used. Because a reduction in torque directly reduces spindle horsepower, this study assumes that the work done to overcome friction is also reduced by the same amount, i.e., about 30 percent. 


\section{REFERENCES}

1. Hubler, G. K. et a1., eds. 1984. Ion Implantation and Ion Beam Processing of Materials. North Holland PubTishing Company, New York.

2. Picreaux, S. T. and W. J. Choyke, eds. 1984. Metastable Materials Formation by Ion Implantation. North Holland Publishing Company, New York.

3. Savage, J. E. 1984. Meta1 Progress, 126(6):41.

4. 1981. American Machinist. 129(9):63.

5. Hartley, N. E. W. 1978. Ion Implantation Case Studies - Manufacturing Applications. Harwell Report AERE-R9065, Harwe T1, London, England.

6. Peterson, M. B. 1985. Assessment of Government Tribology Programs. PNL5539, Pacific Northwest Laboratory, Richland, Washington.

7. Potter, 0. I. et al. 1983. J. Metals. 35(8):17.

8. Schulson, F. M. 1980. Phil. Mag. 42(4):463.

9. Hatschek, R. L. March 1983. "Coatings: Revolution in HSS Tools," American Machinist Special Report. Volume 752.

10. Kodama, M. and R. E. Bunshah. 1982. Thin Solid Film, 96(1):Volume 53.

11. Stiglish, J. J. and R. A. Hetz. 1982. Ceram. Eng. Sci. Proc. 3(8):414.

12. Chen, C. H. et al. "Wear of Laser Processed Cast Iron," preprint.

13. Ahman, Leif. 1984. Met. Trans. A. 15A(10):1829.

14. Mukherjee, K. and J. Mazumder, eds. 1981. Lasers in Metallurgy. Metallurgical Society of AIME, Warrendale, PennsyTvania.

15. Steimetz, J. D. 1984. "Precision Electron Beam Heat Treating." Paper presented at the 2nd Biennial International Machine Tool Technical Conference, September 5-13, 1984. Chicago, Illinois.

:6. Kirvonen, J. K. 1983. "Industrial Application of Ion Implantation." Paper presented at the Materials Research Meeting, November 1983. Boston, Massachusetts.

1.7. Henderer, V. 1983. "Performance of Titanium High Speed Steel Drills." Paper presented at the 11th North Anerican Metalworking Research Conference, University of Wisconsin, May 24-26, 1983. Madison, Wisconsin. 
18. DoA11 Company, product 1iterature. DoAll Company, 254 Laurel Avenue, Des Plaines, Illinois 60016.

19. Wright, P. K. and R. S. Rao. 1983. "Friction Reduction in Machining and Forming." Paper presented at the 11th North American Metalworking Research Conference, University of Wisconsin, May 24-26, 1983. Madison, Wisconsin. 


\subsection{THE METALWORKING INDUSTRIES}

\subsection{DESCRIPTION OF THE METALWORKING INDUSTRIES}

The industries responsible for most of the metalcutting and metalforming activities in the United States are concentrated in the Standard Industrial Classification (SIC) groups 25 and 33-39 (Ref. 1). They are essentially the metal processing industries of the manufacturing sector (SIC code 3) of the economy. The economic importance of the metalworking industries is large, perhaps disproportionate to their size. Their energy consumption is significant. Their product line includes almost every metal-containing artifact of an industrial civilization; yet they use only about a dozen or so basic metalworking processes.

\subsubsection{Nature of the Metalworking Industries}

The metalworking industries are defined here as those whose operations include metalcutting and metalfoming. Appendix A lists these industries according to the SIC 4-digit classification scheme, so that the major types of products are also shown. The major metalworking industry groups are SIC Group 25, Furniture and Fixtures; Group 33, Primary Metals; Group 34, Fabricated Metal Products; Group 35, Machinery Except Electrica1; Group 36, Electrical and Electronic Equipment; Group 37, Transportation Equipment; Group 38, Instrument and Related Products; and Group 39, Miscellaneous Manufacturing Industries. Not ail the industry groups listed are engaged primarily in metalworking - for example, Group 36, Electric and Electronic Equipment, is certainly not a pure netalwor<ing industry although it processes a large volume of sheet metals. But all to have a substantial investment in metalworking machinery and equip. ment, and for this reason, they are included here.

The products manufactured by the metalworking industries include nearly all metal products necessary to an industrial society. A partial 1 ist of the more important ones includes ferrous and non-ferrous metal rolls, sheets, plates, bars, and shapes; structural metals for bridges and buildings; metalworking machine tools and accessories; cars, trucks, airplanes, and other transportation equipment; and most household appliances. 


\subsubsection{The Economic Importance of the Metalworking Industries}

The metalworking industries employed about 6 million production workers and contributed nearly $\$ 313$ billion to the national income in 1981 (Ref, 2). Table 3.1 provides income and employment data on these industries. The contribution of the metalworking industries to the national income and employment picture is important. With about 10 percent of the total employment, they accounted in 1981 for more than 42 percent of the total national income from the non-agricultural private sector, which comprises the mining, construction, and manufacturing industries.

\subsubsection{Energy Consumption in the Metalworking Industries}

To contribute $\$ 313$ billion to the national income, the metalworking indus tries purchased 3.6 quadrillion Btu (or quads) of electricity and fuels for $\$ 20.2$ billion in 1981 (Ref. 3). Table 3.2 shows the purchased electricity and fuel consumed for heat and power by the metalworking industries in 1981. The major energy consumers are the Primary Metals Industries, first, with 2.24 quads; the Fabricated Metal Products Industries, a distant second, with 0.35 quad; the Transportation Equipment Industries, third, with 0.33 quad; and the Machinery Except Electrical Industries, fourth, with 0.32 quad.

Not all of the 3.25 quads is used in metalworking exclusively; the indus tries considered also include the producers of primary metals and alloys from ores and scrap metals. Table 3.3 shows the electricity and fuels consumption of these primary metals and alloys producers. As shown, their combined energy use is approximately 1.4 quads. Subtracting this amount reduces the energy used in metalworking operations to 1.8 quads. The 1.8 quads figure is the target energy consumption that surface modification technologies seek to reduce through their application to metalworking machines.

\subsection{MACHINERY AND EQUIPMENT IN THE METALWORXING INDUSTRIES}

Metalworking machines are used either for metalcutting or metalforming. The major types of metalcutting machine tools are turning, boring, drilling, milling, grinding, cutoff and sawing, broaching, and finishing machines. The major types of metalforming machine tools are punching and shearing machines, bending and forming machines, and presses and forges. 
TABLE 3.1. Income and Employment in the Metalworking-Intensive Industries, 1981

\begin{tabular}{|c|c|c|c|c|}
\hline \multirow{2}{*}{\multicolumn{2}{|c|}{ SIC Description Group }} & \multirow{3}{*}{$\begin{array}{l}\begin{array}{l}\text { Contribution to the } \\
\text { National Income } \\
\text { (billions of dollars) }\end{array} \\
\frac{8.4}{}\end{array}$} & \multicolumn{2}{|c|}{ Employment } \\
\hline & & & $\begin{array}{c}\text { AlT } \\
\text { Employees } \\
(1000)\end{array}$ & $\begin{array}{c}\text { Production } \\
\text { Workers } \\
(1000) \\
\end{array}$ \\
\hline 25 & Furniture and Fixtures & & 467 & 376 \\
\hline 33 & Primary Metal Products & 43.3 & 1121 & 861 \\
\hline 34 & Fabricated Metal Products & 44.8 & 1592 & 1173 \\
\hline 35 & Machinery, Except Electrical & 75.7 & 2507 & 1585 \\
\hline 36 & Electrical, Electronic Equipment & 53.6 & 2091 & 1312 \\
\hline 37 & Transportation Equipment & 57.9 & 1900 & 1216 \\
\hline 38 & Instruments, Related Products & 20.1 & 727 & 428 \\
\hline 39 & Miscellaneous Industries & 9.1 & 407 & 304 \\
\hline & Total & 312.90 & 10812 & 7255 \\
\hline & Percent of All Manufacturing & $53.9 \%$ & $44.2 \%$ & $43.1 \%$ \\
\hline & $\begin{array}{l}\text { Percent of All Non-Agricultural } \\
\text { Industries }\end{array}$ & $42.3 \%$ & $9.8 \%$ & $6.7 \%$ \\
\hline
\end{tabular}

(a) Not adjusted for capital consumption.

Source: U.S. Pureau of the Census, Statistical Abstract of the Inited States 1982-83, 102d edition, Washington D.C. 
TABLE 3.2. Purchased Fuel and Electricity Consumption for Heat and Power by Major Metalcutting and Metalforming Industries, 1981

SIC

$\frac{\operatorname{Cod} \theta}{25}$

25

252

2531

254

259

33

331

332

341

335

$\omega \quad 339$

i. 34

341
342
343
344
345
346
347
348
349
35
351
352
353
354
355
356
357
358
359

\begin{tabular}{|c|c|}
\hline $\begin{array}{c}\text { Purchased } \\
\text { (mllilion kwh) }\end{array}$ & $\begin{array}{l}\text { Generafed } \\
\text { Less Sold } \\
\text { (kwh) }\end{array}$ \\
\hline $4,143,2$ & $(S)^{(a)}$ \\
\hline $\begin{array}{r}2,539.8 \\
499.2 \\
213.7 \\
651.7 \\
238.7\end{array}$ & $\begin{array}{l}\text { (S) } \\
(D)(b) \\
(D) \\
--(c) \\
--\end{array}$ \\
\hline $165,959.4$ & $9,058.0$ \\
\hline $\begin{array}{r}59,520.4 \\
11,618.9 \\
78,465.6 \\
1,033.2 \\
11,458.4 \\
2,337.7 \\
1,524.4\end{array}$ & $\begin{array}{c}5,441.2 \\
\text { (S) } \\
\text { (S) } \\
\text { (D) } \\
\text { (S) } \\
\text { (D) } \\
=-\end{array}$ \\
\hline $25,539.1$ & (S) \\
\hline $\begin{array}{r}2,185.8 \\
2,396.9 \\
723.4 \\
5,129.2 \\
1,601.6 \\
5,528.1 \\
2,019.9 \\
1,454.1 \\
4,502.0\end{array}$ & $\begin{array}{l}\langle D\rangle \\
(D) \\
(D) \\
(D) \\
(S) \\
17.9 \\
(D) \\
\text { (S) }\end{array}$ \\
\hline $31,569.1$ & 126.9 \\
\hline $\begin{array}{l}2,597.3 \\
2,055.7 \\
5,764.6 \\
3,860.0 \\
1,930.6 \\
4,932.5 \\
4,553.6 \\
2,644.8 \\
3,230.2\end{array}$ & $\begin{array}{l}21.6 \\
(D) \\
23.6 \\
6.7 \\
(D) \\
(S) \\
(D) \\
0.1 \\
(D)\end{array}$ \\
\hline
\end{tabular}

Purchased

(trililion 8tu)

Partition and Fixtures

MIscellaneous Furnlture and Fixtures

Primary Metal Industries

last Furnace and Baslc Steel Products

Iron and Steel Foundrles

Primary Non-Ferrous Mtals

Secondary Non-Ferrous Metals

Non-Ferrous Rolling and

Miscellaneous Primary Metal Products

Fabricated Metal Products

Hotol Cans and Sh1pping Contalners

Cutlery, Hand Tools and Hardware

Plumbing and Heatling, Except Electric

Fabricated Structural Metal Products

Screw Machine Products, Bolts, etc.

Metalforgling and Stamplng

Metal Servlces N.E.C.

Ordnance and Accessorles

Miscellaneous Fabricated Metal Products

MachInery, Except Electrlcal

\section{Engines and Turblines}

Farm and Garden Machinery

Construction and Related machinery

Metaluorking, Machinery

Special Industry Machlnery

General Industry Mach Inery

office and Computing Machines

Refrlgeration and Service Machl nery

Misceilaneous Machinery, Except Electrical
Fuels

32.0

17.1

4.5

2.0
5.9

2.6

Purchased

Fuels and

Electrlc Energy

(tr1IIlon Btu)

46.2

25.7

6.2
2.7

8.1
3.4

$1,674.4$

$2,240.6$

$1,192.3$

115.2

165.1

35.3
113.5

113.5

21.9

264.7

22.4

20.4

8.3
6.5

13.

73.4

32.4

12.8

33.2

2127.1

21.6
24.1

24.1
48.2

22.5

14.4

34.9

10.8

21.0

19.6
$1,395.4$

154.9
432.8

432.8
38.8

152.6

39.0

351.9

29.8

28.5

48.766 .2

18.7

92.3

39.3

17.8

324.8

30.4

31.1

678.9

35.7

21.0

51.7

26.4

30.0

30.7 


\section{TABLE 3.2. (contd)}

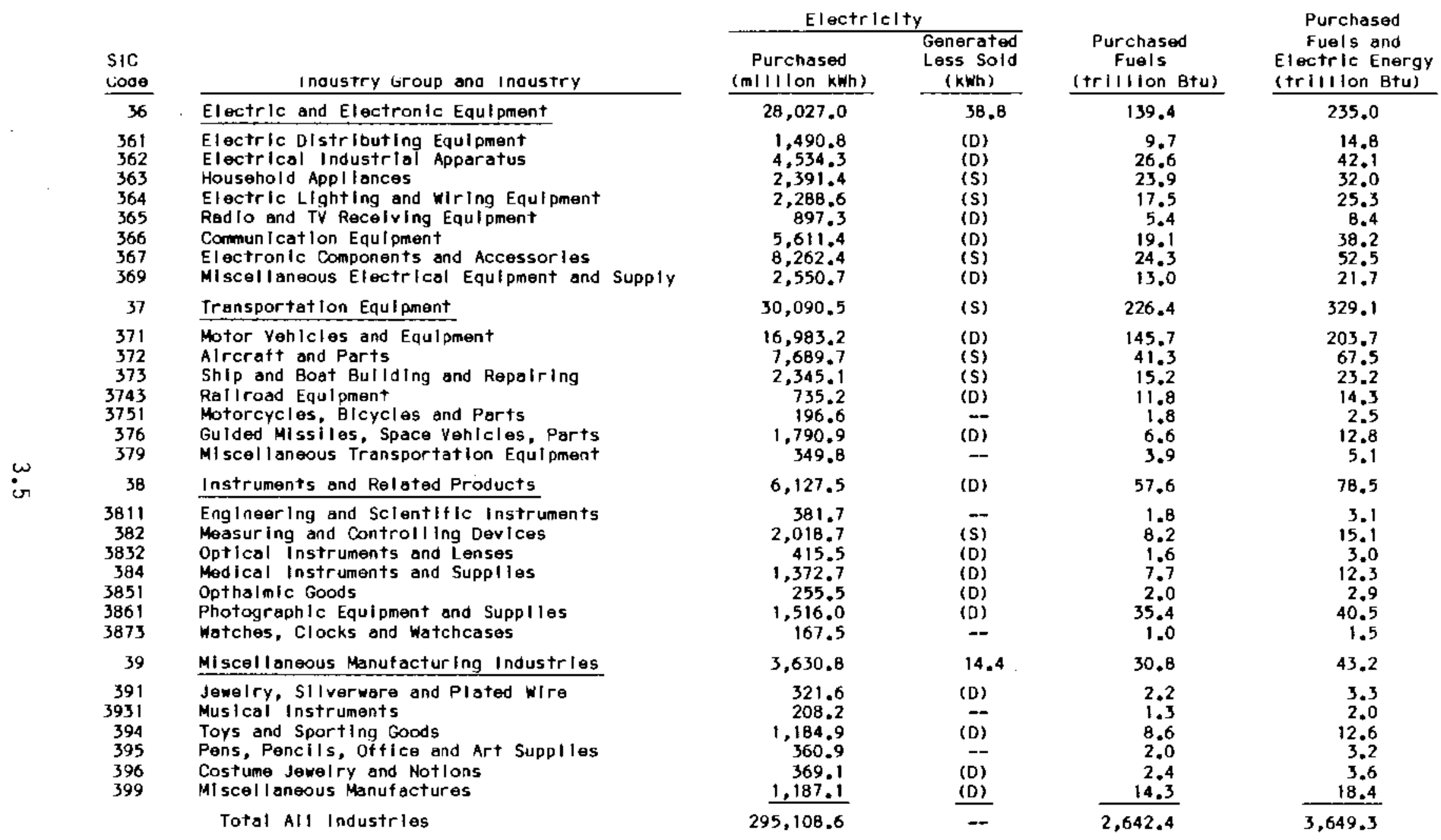

(a) (S) - wltheld because estlmate did not meet publication standards on the basis of elther the response rate or a consistency revlew.

(b) (D)-withheld to avold disclosing data for individual companies.

Source: U.S. Bureau of the Census 1982, Census of Manufacturers, June 1983. 
TABLE 3.3. Non-Metalworking Energy Uses in the Metalworking-Intensive Industry Group SIC 33

\begin{tabular}{llc} 
SIC \\
Code & \multicolumn{1}{c}{ Industry } & $\begin{array}{c}\text { Purchased } \\
\text { Fuel and } \\
\text { Electricity } \\
\text { (Trillion Btu) }\end{array}$ \\
3312 & Blast Furnace and Steel Mills & $644.4($ a) \\
3313 & Electrometallurgical Products & 54.8 \\
332 & Iron and Steel Foundries & 154.9 \\
333 & Primary Non-Ferrous Metals & 432.8 \\
335 & Non-Ferrous Foundries & 39.0 \\
339 & Miscellaneous Primary Metal Products & $\frac{27.1}{1353.0}$
\end{tabular}

(a) This is $50 \%$ of the total purchased fuel and electricity used in Industry 3312. Fifty percent is approximately the ratio of energy used in refining to that used in finishing (e.g., rolling, drawing) in an integrated steel mill.

Source: U.S. Bureau of the Census, 198? Census of Manufacturers (MC82-5-4, Part 1), June 1983.

Of interest to this study are statistics on the number of machine tools in use in the United States and data on the horsepower of the spindle drive of the machines. The horsepower data are important because the horsepower (watts) multiplied by the operation time (hours) provides an estimate of the energy consumption ( $\mathrm{kWh}$ ) of a machine. Statistics have been compiled by the Machinist Information Service in its 13th American Machinist Inventory of Metalworking Equipment 1983 (Ref. 4). DHR surveyed the spindle horsepower of machine tools using machine specification data supplied by machine tool manufacturers. The results of the survey are given in Appendix B. The major metalworking machine tools are described below.

\subsubsection{Metalcutting Machines and Accessories}

\subsubsection{Turning Machines}

Turning machines remove metal from the surface of a rotating workpiece through the action of a cutting tool pressed against it. Turning is done on a 
lathe. Turning lathes are classified according to chuck size (usually up to $20^{\prime \prime}$, function (tracer or tool room, turn, or turn and bore), spindle orientation (vertical or horizontal), or the number of spindles (one or more). The power rating of the electric motor drive of a turning machine spindle ranges from 4 to 150 horsepower (hp). Turning machines and most metalcutting machines are usually also equipped with several fractional horsepower motors to circuTate the coolant and the lubricant or to assist in positioning the workpiece.

Turning tools can be single point, box, form, or cutoff tools and cutting inserts. The major types of tool materials are high speed steels, carbides, and ceramics. Except for ceramic tools, all turning tools are amenable to surface modification to increase hardness and wear resistance.

In 1983, there were approximately 366,000 turning machines in use in the United States. Nearly one-half were used by Industry Group SIC 35, Machinery Except Electrical.

\subsubsection{Boring Machines}

Boring mills are designed to enlarge or finish holes in a workpiece using a rotating and cutting motion of a boring tool. Boring machines are usually classified according to spindle orientation (horizontal, vertical, or both; some spindles can be rotated about a center) or the degree of precision afforded (precision boring mills can position and bore to a few thousandths of an inch; jig boring mills need a fixture to position the workpiece). Boring tools are essentially similar to cutting tools in both design and material. The rating of the main spindle drive motor in boring machines varies from 8 hp to 120 ho.

In 1983, there were approximately 45,000 boring machines in the United States. Nearly one-half of them were used by Industry Group SIC 35.

\subsubsection{Drilling Machines}

Drilling machines produce holes in solid metal, usually with a rotary end cutting tool. Metal is removed as the rotating end cutter penetrates the workjiece and cuts the metal with its lips. As with turning or boring machines, drilling machines are also classified according to spindle orientation, the degree of precision afforded, or the type of hole drilled (deep hole drilling, 
as needed for gun barrels, versus small hole drilling). Drilling machines' drive motors are comparable to boring machines', in the 8-120 hp range. The most common have a vertical or upright spindle. Most are equipped with a 15 hp spindle drive motor.

Drills vary in shape and size. They can be simple jobber, low helix, high helix, straight shank oil hole, three flute core, left hand, straight flute, step, or subland drills. Drill materials are high speed steels or carbides, the two major cutting tool materials. All HSS drills can be surface modified.

There were nearly 300,000 drilling machines in the United States in 1983; approximately one-third were used in SIC Group 35, Machinery Except Electrical.

\subsubsection{Milling Machines}

The rotating multiple tooth cutter of a milling machine produces surfaces of almost any orientation on a workpiece. The desired orientation is obtained by using the appropriate cutter tooth size and adjusting the relative orientation and direction of motion of both the cutter and the workpiece. Milling machines are classified according to spindle orientation vertical or horizontal), design (knee and column or bed), or application (general purpose, profiling, duplicating). Most milling machines have spindle drive motors rated from 3 to $30 \mathrm{hp.}$

Milling cutters are classified as peripheral or end, depending on the location of the cutting teeth. Specialized milling cutters, such as slotting and sawing cutters, and inserts are also available. Materials for milling cutters are high speed steel and carbides. All HSS drills can be surface modified.

The number of milling machines in the United States was approximately 234,000 in 1983. Again, one-half were used by SIC Group 35.

\subsubsection{Grinding Machines}

Grinding machines remove materials from the surface of a workpiece using the abrasive wear action of a rotating grinding wheel. High friction coefficients are desirable in grinding. Grinding machines are classified according to purpose (precision, for a specific surface finish, or non-precision, for 
stock removal without regard to surface finish) or the geometry of the desired surface (cylindrical for curved or round surfaces and surface for planes). The spindle drive of grinding machines can range from fractional horsepower (hp) for hand grinding of cutting tools in the shop to 50 hp for large parts.

Grinding is done using abrasive wheels, loose abrasives, or abrasive grinding belts. Typical abrasive materials are aluminum oxides, silicon carbides, and diamond particles. Because none of these materials is likely to be amenable to surface modification, at least in powder form, grinding machines are not considered for surface modification technologies in this study.

\subsubsection{Cutoff and Sawing Machines}

Cutoff and sawing machines use thin abrasive wheels or toothed metal blades and bands that rotate or reciprocate at a high speed to chip metal from the workpiece in a deep, narrow line, thus cutting the workpiece with a minimum of material removal, applied force, and power. Cutoff and sawing machines are classified according to cutting device type (abrasive wheel or saw) or motion (hacksaws reciprocate, band saws cut with a continuous motion of the blade). The spindle motor drive of cutoff and sawing machines ranges vary widely. The smallest have fractional horsepower motors; a few of the larger models have motors rated at up to $150 \mathrm{hp}$; the average horsepower value for sawing machines is around $5 \mathrm{hp}$.

Cutoff and sawing tools are hacksaw blades, band saws, circular saw blades, and abrasive wheels. Except for the abrasive cutoff wheels, which are bonded abrasive particles, and carbide insert tooth saws, all other cutoff and sawing tools are surface modifiable because they are made of carbon steels, alloy tool steels, and high-speed steels.

There were approximately 170,000 cutoff and sawing machines in the united States in 1983. About one-third were used by the Industry Group SIC 35.

\subsubsection{Broaching Machines}

Broaching machines remove materials on the surface of a hole to enlarge it by the cutting action of a broach, i.e., a tapered cutting tool with many transverse cutting edges, that is pushed or pulled, small end first, through the hole. Broaching machines are classified according to the direction of 
travel of the broach (horizontal or vertical), the type of broaching operation (external for surface broaching and internal for hole broaching), or the drive (mechanical, hydraulic, pneumatic). Broaching machines are rated in tons, e.g., 5 tons, 10 tons, up to 50 tons, with 15-20 tons the average size. The motor drive of broaching machines is similar to that of presses of comparable tonnage rating, i.e., from 10 to $50 \mathrm{hp}$.

Broaching tools are either solid or shell broaches. Some broacbes have carbide inserts or rings as cutting edges. The most commonly used broach materials are the high-speed steels, which are readily amenable to surface modification.

Broaching is a highly specialized operation, and the number of broaching machines in the Inited States is relatively low, nearly 16,000 in 1983. The Industry Groups SIC 35 (Machinery Except Electrical) and SIC 37 (Transportation Equipment) use about one-third of these machines each.

\subsubsection{Finishing Machines}

Finishing machines are specialized equipment such as honing and lapping machines. Metal removal, and therefore the power required, is minimal because the purpose of the operation is to finish machining the workpiece to the desired dimensions. In honing, the abrasive action of a honing stone is applied lightly and is usually set to rotate and reciprocate at the same time that it removes a very thin (a few thousandths of an inch) layer from the workpiece surface. In lapping, loose or bonded abrasive particles are used to polish the workpiece surface to extreme accuracy and finish dimensions. Honing and lapping machines have motor drives ranging from $0.25 \mathrm{hp}$ to $10 \mathrm{hp}$.

The tools for finishing machines are abrasive wheels as well as loose abrasive and honing stones. These tools are not likely to be surface modifiable, and thus finishing machines are not considered in this study.

\subsubsection{Metal forming Machines}

\subsubsection{Punching Machines}

Punching machines use a die to cut shapes from metal sheets, plates, or strips in one or more strokes, or punches, of the die. Punching machines are 
essentially presses designed for a particular type of punching operation. Most punch presses are mechanical. The major types of punching machines (and operations) are blanking, parting, piercing, notching, lancing, and trimoning. In blanking, a shape is cut out of a metal sheet in a single stroke of the die. In parting, a thin strip of material is cut between two blanks to separate them. In piercing, holes are punched in sheet metal. In notching, metal at the edge of the strip or the blank is punched out. In lancing, a line is cut without severing any material from the metal strip, usually as preparation for bending or other subsequent forming operations. In trimining, excess metal is punched out. A punching machine can perforn more than one punching operation.

The basic tool for punching is a mating punch and die set. Steel rule and template dies are commonty used. In a steel rule die set, the punch consists of an HSS or carbon steel strip that is edge-mounted in order to outine the shape to be cut on a piece of steel-backed plywood; the die is a plate of carbon or alloy steel with a hole of the same shape as the part to be punched. In a template die, the punch is a plate of alloy or tool steels in the shape of the part to be punched; the die is assembled from strips of the same material as the punch in such a way that the punch fits into it.

Punches and dies are designed to perform a certain number of production runs, from a few hundred to 100,000. Edge wear is a major cause of premature die failure. Because most punches and dies are made of steels (carbon, alloys, HSS), surface modification of edges would help reduce friction and wear.

Mechanical punch presses are usually powered by an electric motor. The motors range from 0.5 to $25 \mathrm{hp}$, with the average around $15 \mathrm{hp}$. Like most other forming machines, most punching machines are run continuously in a high-volume production setting. The number of punching machines in the United States was about 73,000 in 1983; one-third were in use in Industry Group 34, Fabricated Metal Products.

\subsubsection{Shearing Machines}

Shearing machines (or shears) cut sheet, plate, or strip metals using cutter blades. The shearing process is complete when the upper movable blade has penetrated the stock to a depth that is sufficient to cause the remaining 
unpenetrated portion of the stock to fracture and separate. Triangular, square, or rectangular shapes are obtained using a straight blade shearing machine. Rotary shearing machines cut curved contours using a set of tapered revolving circular cutters. Shear blades and rotary cutters of most shearing machines are mechanicalty actuated; hydraulic or pneumatic shears are also used.

Shear blades are made from tool steels, carbon, or alloy steels. Blade edges are often hard faced. Edge inserts are also used. Most shear blades are designed for high-volume production. Like punching machines, shearing machines are powered by electric motors rated on the average at $15 \mathrm{hp.} \mathrm{In} \mathrm{1983,} \mathrm{there}$ were 38,000 shears in the United States, about one-third of them in use in Industry Group 34, Fabricated Metal Products.

\subsubsection{Bending and Forming Machines}

Bending and forming machines are used to bend and form bars, tubes, and wires. A piece of stock is bent by a die clamp that presses it against a rotating form (draw bending) or that whips it against a fixed form or by a three roll arrangement in which two rolls support the stock and a third roll bends it. In the bending of tubings, mandrells are used to prevent tube collapse.

Bending and forming tools are forms, dies, and mandrells. The materials used for bending tools are hardened tool and low carbon steels for high-production runs and wood or aluminum if the stock is soft or only a few samples are made.

Bending machine types include press brakes, bending rolls, rotary bending and forming machines, and bending presses. Approximately one-third of the 77,000 bending machines in the United States in 1983 were used in Industry Group 34, Fabricated Metal Products.

Friction in bending is minimal. Because most tube forming operations, such as tube flaring and flanging, rely on frictional forces to shape the metal, bending and forming machines are not considered in this study. 


\subsubsection{Presses and Forges}

Presses are used primarily for forming thin section stock, such as sheet metals and plates, whiTe forges are used for heavy section stocks such as billets and slabs. These machines are essentially similar in design, but forges are much bigger and are capable of higher capacity or tonnage rating. Metal is formed with presses and forges by punching on the stock over a mating die. The ram to which the punch is mounted is actuated hydraulically, mechanically, pneumatically, or by gravity as in drop hammer forges.

Many design options for presses and forges exist. Table 3.4 shows some of them.

Forging machines are, classified as open or closed die. In closed die forging, the flow of the workpiece metal is confined within the die; in open die forging, it is not. Within each type of forge, one can have hammers (drop, counterflow) or presses.

The basic forging and pressing tools are punches and dies. The properties of the alloys to be formed, the working temperature, the number of parts to be produced, and the past production rate are the major considerations in selecting tool materials. Common tool materials are hardened alloy and tool steels with good strength, hot hardness, and resistance to abrasion.

The rams and punches of presses and forges are driven directly or indirectly by electric motors. These motors lift the hammers, pressurize the fluids ir accumulators for subsequent release at the ram at a high rate, or drive the punch directly using a variety of drive mechanisms. Thus, although a hydraulic press may be rated at 500 tons, it could be powered by just one 25 hp electric motor. Motors used in forges and presses are rated from 10 to 150 hp. For upset forging machines, for example, the average motor rating varies from $10 \mathrm{hp}$ to a rated forging capacity of 125 tons to $150 \mathrm{hp}$ at 1,800 tons. In 1983, there were approximately 280,000 presses and forges in the United States, about one-third of them used by Industry Group 34, Fabricated Metal Products. 
TABLE 3.4. Characterization of 18 Types of Presses (Ref. 5)

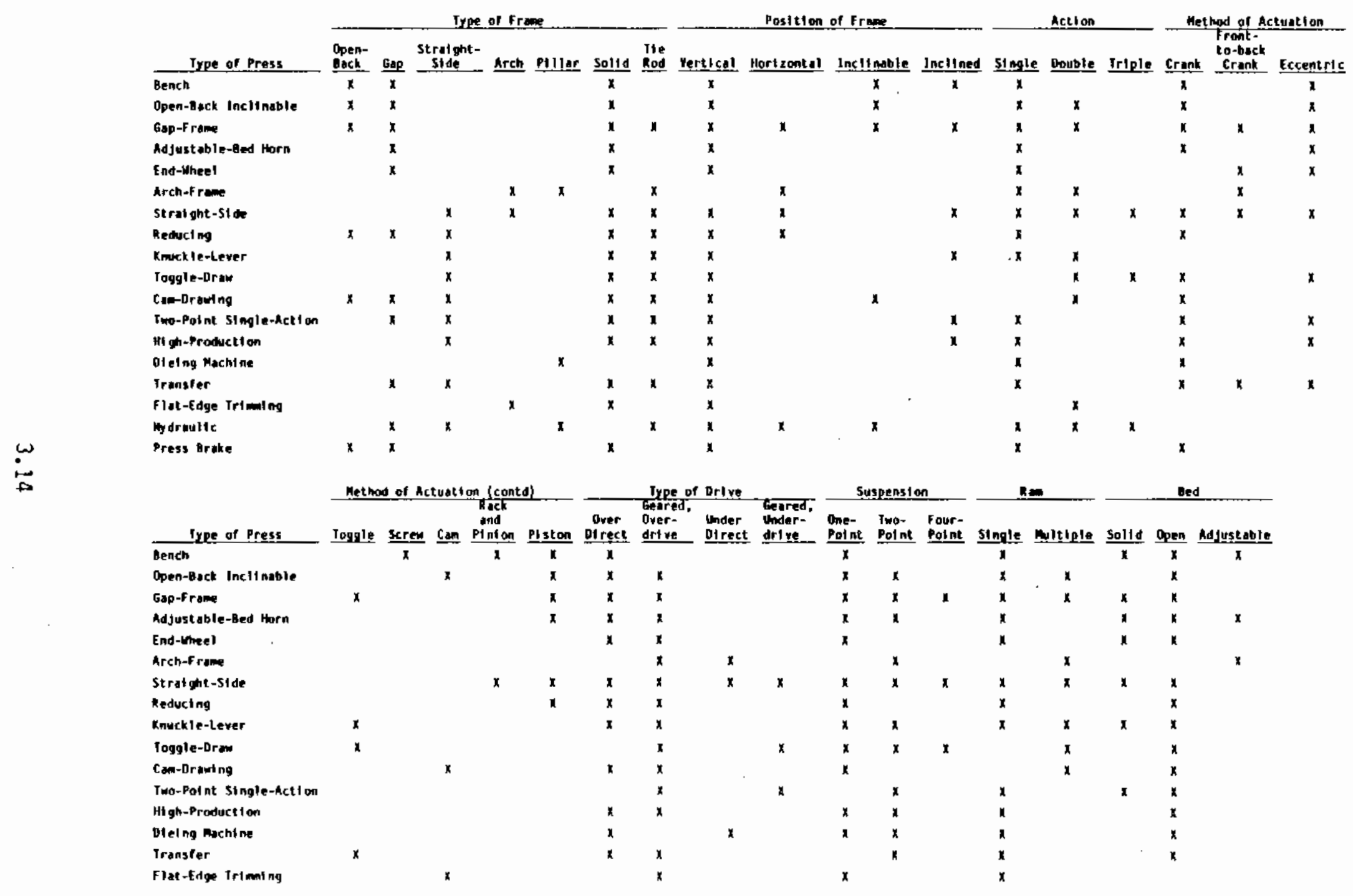




\section{REFERENCES}

1. Office of Management and Budget. 1972. Standard Industrial Classification Manual. U.S. Government Printing office, Washington, D.C.

2. II.S. Bureau of the Census. 1983. Statistical Abstract of the United States, 1982-83. 102nd ed. U.S. Government Printing Office, washington, T.C.

3. 1..S. Bureau of the Census. June 1983. 1982 Census of Manufacturers. MC82-S-84 (Part 2), Government Printing Office, Washington, D.C.

4. American Machinist. November 1983. The 13th American Machinist Inventory of Metalworking Equipment. American Machinist, McGraw-Hill Inc., New York.

5. Schey, J. A., ed. 1972. American Deformation Processes, Friction and Lubrication. 2nd ed. Marcel Dekker, Inc., New York. 



\subsection{ENERGY CONSERVATION IMPACT MODELING}

The model used to assess the impact of surface modification technologies on energy uses in metalworking is described in this section. It is a simple model. From an estimate of the tribological sink in the metalworking industries and known data on the reduction in friction and wear achievable with surface modified tools, the energy which can be conserved by using these tools is derived.

\subsection{ANALYSIS OF ENERGY USE IN METALWORKING}

Metalworking-related energy uses can be classified as either direct or indirect. Energy is expended directly to deform and fracture the workpiece, overcome friction at the tool-workpiece interface, and operate the support systems of the machine tool during metalworking. Indirect energy uses can be classified as machine-, as manufacturing system-, or as economy-specific. Machine-specific energy uses are the embodied energies in worn tools and other consumables and the energy used by the machine itself when it is idling. Manufacturing system-specific energy uses are those changes in energy use in the manufacturing system (of which the machine tool is a part) that are traceable to changes in metalworking conditions at the machine tool itself. Economyspecific energy uses are changes in the total energy use of the economy as a whole that are traceable to the quality of the metalworked product. Table 4.1 lists these types of energy uses and shows the probable effects of reducing friction and wear. Most of the effects noted are qualitatively self-evident, but few have been quantitatively modeled or experimentally evaluated. The model developed in this study considers only the effects of reducing wear and friction on the direct energy used to overcome friction at the tool-workpiece interface and the energy use (indirect) as embodied in worn tools.

\subsection{THE GENERAL ENERGY CONSERVATION IMPACT MODEL}

A flow chart for the model is shown in Figure 4.1. Two estimates contribute to the tribological sink. The first is the frictional sink: the 
TABLE 4.1. Impact of Friction and Wear Reduction on Energy Use in Metalworking

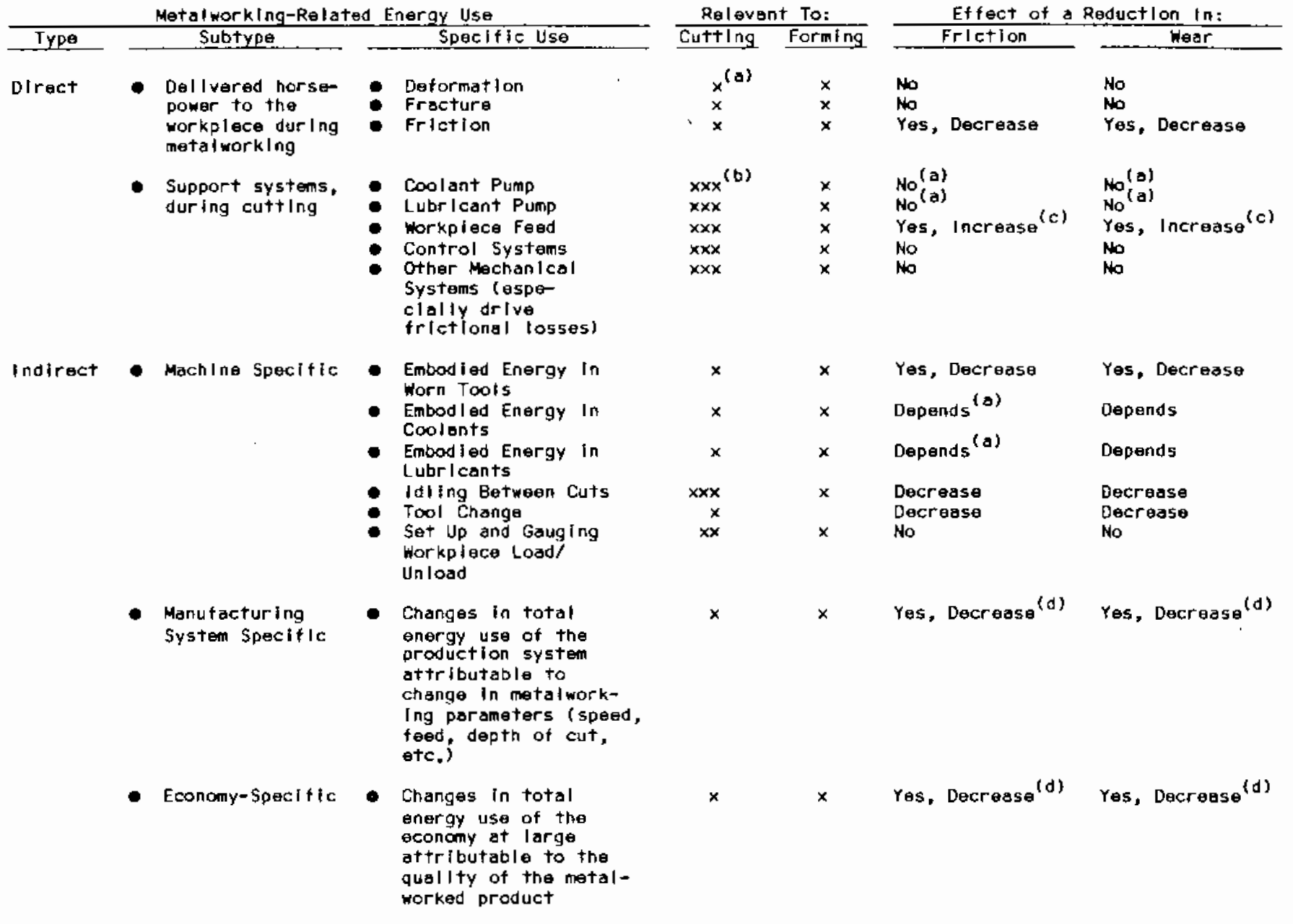

(a) It might be argued that with reduced frictlon and wear at the tool-workplece interface the energy used at their locations can be reduced aiso. For example, at reduced frlctlon, the workplece temperature is lower and there Is a correspondingly lesser need for coolant and lubrlcant pumping. However, in practice, the lubrlcant and coolant lavels and pumplng rates are premset and unllkaly to be changed as cuttling proceeds.

(b) $\quad x=$ Relevant

$x x x=$ Yery relevant

(c) Because the feed rate can be increased.

(d) But very difflcult to quantify. 


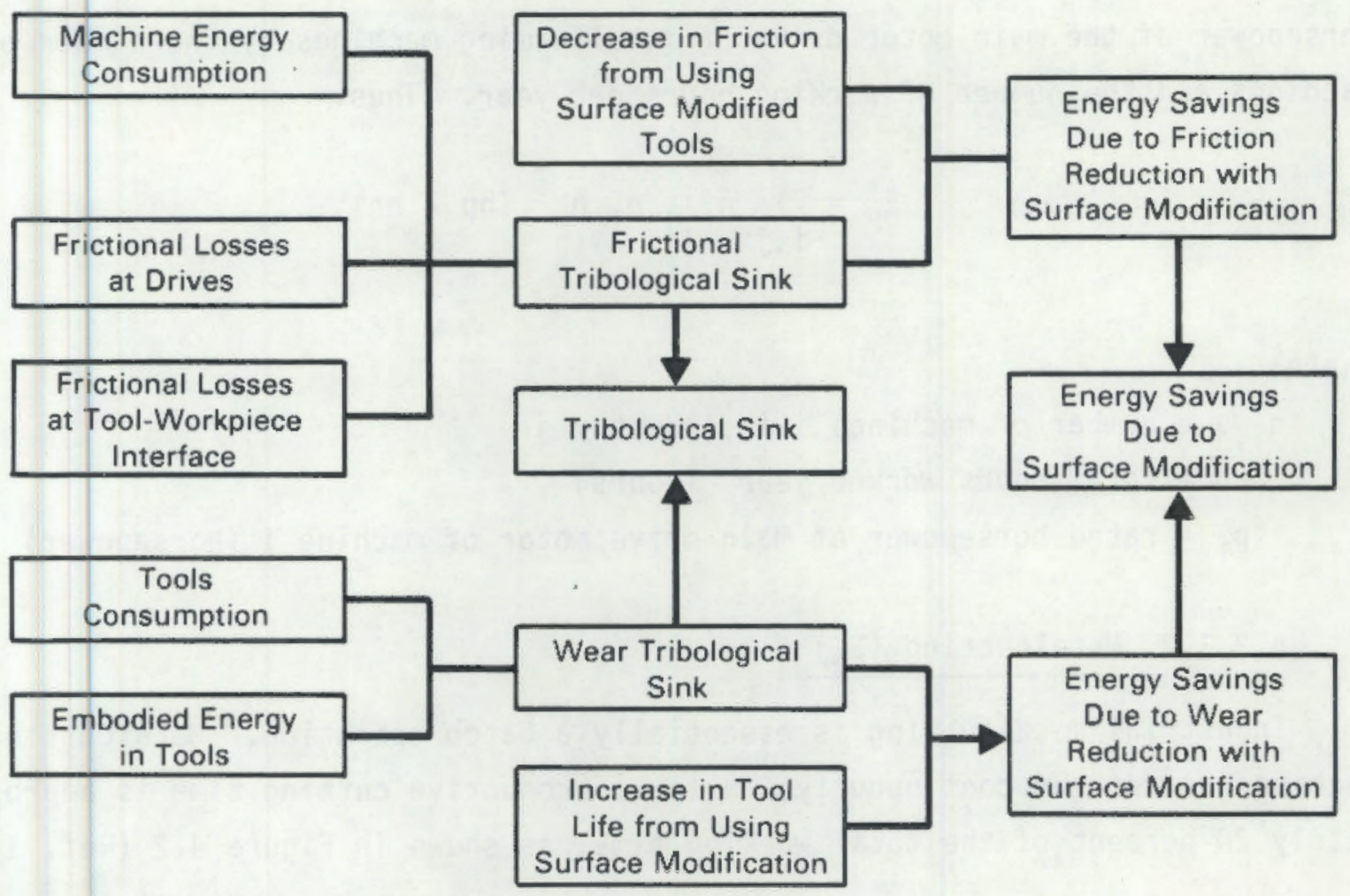

FIGURE 4.1. Energy Savings Estimation Model

sum of frictional losses at the machine drive systems and the tool-workpiece interface. The second is the wear sink: the sum of the energies embodied in the alloys used to make the worn metalworking tools. The tribological sink is the sum of the two estimates. The energy savings due to surface modification equal the tribological sink adjusted downward to take into account increased tool life and the reduction in friction.

\subsubsection{Machine Energy Consumption (E)}

\subsubsection{Metalforming $\left(E_{f}\right)$}

With few exceptions, industrial metalforming--especially in Industry Group 34, Fabricated Metal Products, which uses most of the U.S. metalforming machines--is a high production operation. The machines often run continuously in one, two, even three shifts and at their rated capacity. The model estimates machine energy consumption in metalforming by multiplying the rated 
horsepower of the main motor drive of metalforming machines by the number of machines and the number of working hours per year. Thus:

$$
E_{F}=\sum_{i, j} n_{i, j} P_{i} h \quad(h p-h r)
$$

where:

$$
\begin{aligned}
n_{i, j} & =\text { number of machines } i \text { in industry } j \\
h & =\text { total hours worked/year (hours) } \\
p_{i} & =\text { rated horsepower of main drive motor of machine } i \text { (horsepower) }
\end{aligned}
$$

\subsubsection{Metalcutting $\left(E_{e}\right)$}

Industrial metalcutting is essentially a batch operation. Metalcutting machines do not run continuously; in fact, productive cutting time is approximately 20 percent of the total working time, as shown in Figure 4.2 (Ref. 1).

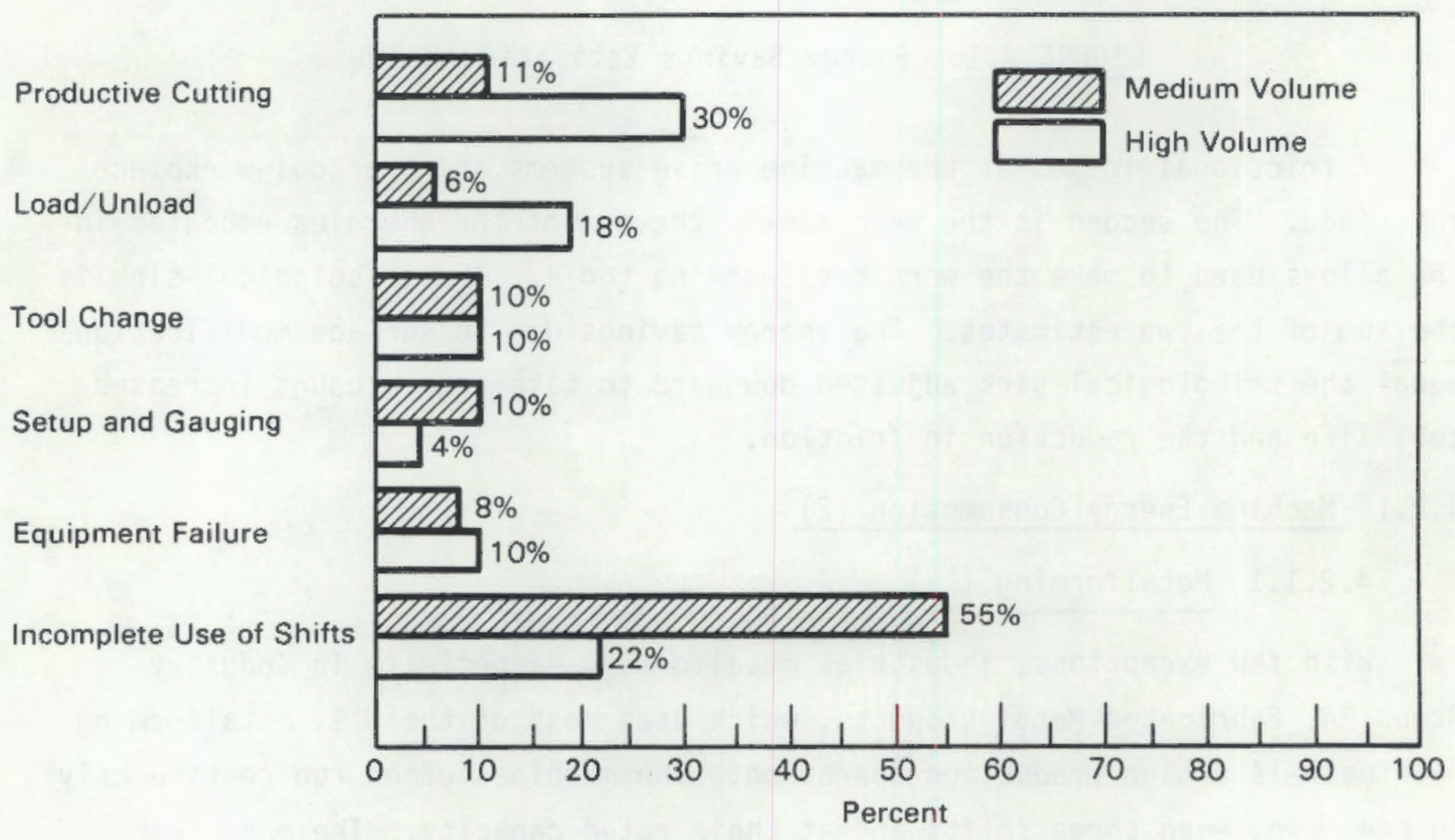

FIGURE 4.2. Machine Utilization in Metalcutting (Ref. 1) 
Furthermore, metalcutting machines, whether operated manually or by computer, are run at optimum conditions for the material being cut and the type of cut to be made. Taking these considerations into account $P_{i}$ (as defined above) is now written as:

$$
P_{i}=\frac{1}{e} \sum_{i, j} P_{a, i} \frac{C_{a, i}}{\frac{C_{a}}{C} a, i}
$$

where:

$$
\begin{aligned}
& c_{a, j}=\text { consumption of alloy a by industry } j \text { (ton/year). } \\
& p_{a, i}=\text { power required at the tool point to perform a standard opera- } \\
& \text { tion on machine } i \text { on an alloy a }(h p) \\
& E_{c}=\sum_{i, j} n_{i, j}\left[P_{a, i}\left(\frac{C_{a, i}}{\sum_{a} C_{a, i}}\right)\right] \frac{h}{e} s \quad(h p-h r)
\end{aligned}
$$

where:

$s=$ percent of the total working time spent $(\%)$

$e=$ efficiency of the spindle drive system (\%)

The term $P_{a, i}$ is machine-, process-, and alloy-specific. Equations to compute $\mathrm{P}_{\mathrm{a}, \mathrm{i}}$ from machining conditions are available from handbooks (Ref. 2,3,4). For example, for turning, milling, and drilling:

$$
\begin{gathered}
P_{a, \text { turning }}=12 \times d \times f r \times V_{c} \times P_{a} * \\
P_{a, m i l l i n g}=w \times d \times f m=w \times d \times f t \times h \times r p m \times P_{a} * \\
P_{a, d r i l l i n g}=\frac{D^{2}}{4 f m^{-}} P_{a} *
\end{gathered}
$$


where:

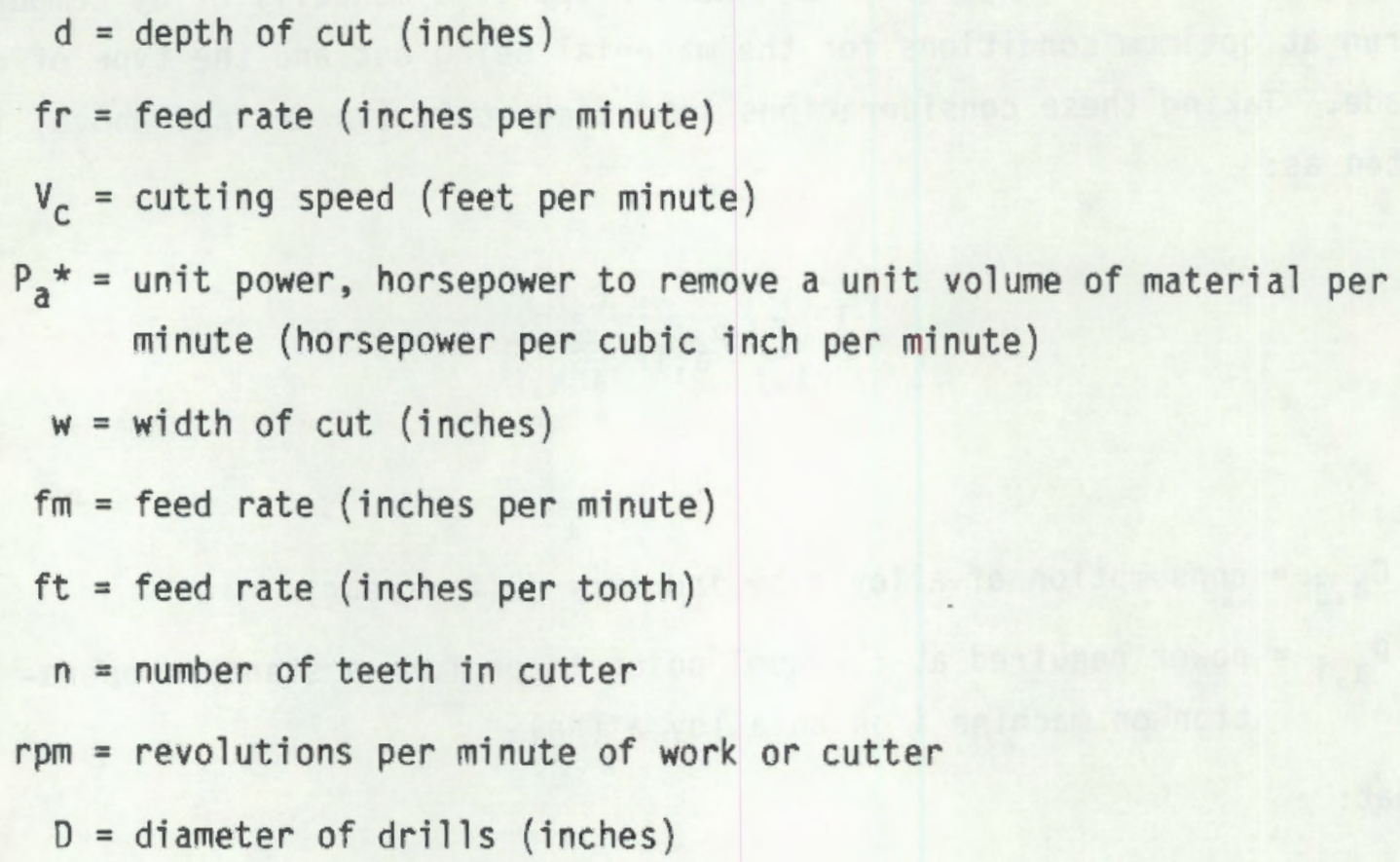

\subsubsection{Frictional Losses at Drive System Z}

Frictional losses at drive systems are caused by inefficiencies in converting the raw electric motor power output to useful horsepower at the tool point. Such inefficiencies arise in the spindle drive systems, which are usually transmission belts and bearings. In terms of the previously defined variables, $Z$ is written as:

$$
Z=(1-e) E \quad(h p-h r)
$$

Handbook data give values for (1 - e) (as a percentage of raw electric motor power output) of up to 25 percent for metalforming machines and 20 percent for metalcutting machines (Refs. 2,3). These values for (1 - e) are assumed in this study.

\subsubsection{Frictional Losses at the Tool-Workpiece Interface I}

From the first principle, frictional losses at the tool point are equal to the power used to overcome friction multiplied by the metalworking time: 


$$
I=\sum_{I, J} n_{I, J}\left[p_{i}(1-e)-p_{w i}\right] h s \quad(h p / h r)
$$

where the new variable, $P_{w i}$, is the power used to form or cut the metal, the term $P_{i(1-e)}$ is the power delivered at the tool point, and the difference $\left(P_{j}(1-e)-P_{w i}\right)$ is the power used to overcome frictional forces. If an efficiency ratio $u$ is now defined as the ratio of the power used to overcome friction to the power used to work the metal:

$$
u=\left(P_{i}(1-e)-P_{w i}\right) / P_{w i}
$$

I can be rewritten as:

$$
I=\sum P_{i} \frac{(1-e)}{(u+1)} u n_{i j} h s s \quad(h p / h r)
$$

In defining $u$, this study assumes that all work done at the tool-workpiece interface is either frictional or metalworking (e.g., deformation, fracture, or creation of new surfaces). This assumption is also made for metalcutting; it is applicable in metalforming only when the work also includes redundant work which is the extra work that must be expended when a material does not deform homogeneously.

\subsubsection{The Efficiency Ratio $u$ in Metalcutting}

The efficiency ratio $u$ in metalcutting is estimated using the orthogonal cutting model. This model describes the forces at the cutting tool when its edge is perpendicular to the direction of relative work/tool motion. A summary of the orthogonal cutting model is shown in Figure 4.3. Although most metalcutting operations are oblique, i.e., with the edge of the tool not perpendicular to the direction of the work/tool motion, the orthogonal cutting model provides a good approximation of the forces and work done in metalcutting.

Using the symbols and equations defined in Figure 4.3, the metalcutting efficiency ratio ${ }_{c}$ in metalcutting can be written as: 


\begin{tabular}{lll}
\hline \multicolumn{1}{c}{ Quantity } & \multicolumn{1}{c}{ Equation } \\
\hline \hline Coefficient of friction & $u=\frac{F_{t}+F_{\mathrm{c}} \tan \alpha}{F_{\mathrm{C}}-F_{\mathrm{t}} \tan \alpha}$ & (1) \\
\hline Friction force & $\mathrm{F}=\mathrm{F}_{\mathrm{t}} \cos \alpha+\mathrm{F}_{\mathrm{c}} \sin \alpha$ & (2) \\
\hline Mean shear strength & $\mathrm{S}_{\mathrm{S}}=\frac{\mathrm{F}_{\mathrm{c}} \sin \phi \cos \phi-\mathrm{F}_{\mathrm{t}} \sin ^{2} \phi}{\mathrm{A}_{0}}$ & (3) \\
\hline Work done in shear & $\mathrm{W}_{\mathrm{S}}=\mathrm{S}_{\mathrm{s}}[\cot \phi+\tan (\phi-\alpha)]$ & (4) \\
\hline Work done in overcoming friction & $\mathrm{W}_{\mathrm{f}}=\frac{\mathrm{F}}{\mathrm{A}_{0}} \frac{\sin \phi}{\cos (\phi-\alpha)}$ & (5) \\
\hline Total work done in cutting & $\mathrm{W}_{\mathrm{n}}=\frac{\mathrm{F}_{\mathrm{c}}}{\mathrm{A}_{0}}$ & (6) \\
\hline
\end{tabular}

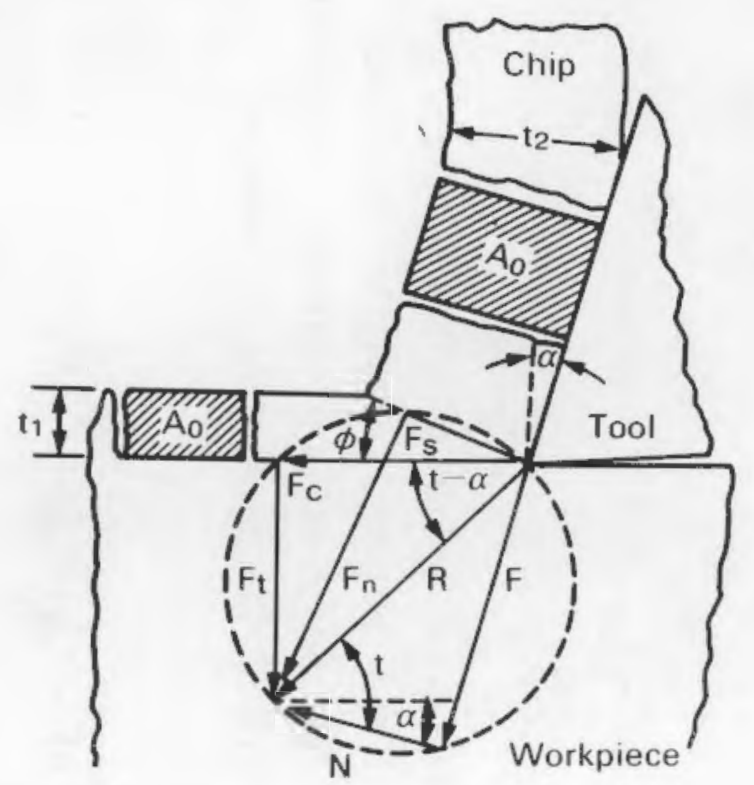

where $A_{0}=$ cross-sectional area of chip before removal from workpiece, sq. in.

$\mathrm{F}$ = friction force; force component acting between tool face and sliding chip, lb

$\mathrm{F}_{\mathrm{c}}=$ cutting force; force component acting in direction of tool travel, lb

$F_{\mathrm{t}}=$ thrust force; force compartment acting in direction perpendicular to surface generated, $\mathrm{lb}$

$\mathrm{S}_{\mathbf{s}}=$ mean shear stress on shear plane; mean shear strength of metal being cut, psi

$W_{\mathrm{f}}=$ work done in overcoming friction between chip and tool per unit volume of metal removed, in.-lb per cu in.

$W_{n}=$ total work done in cutting per unit volume of metal removed, in.-lb per cu in.

$W_{\mathrm{s}}=$ work done in shearing of metal per unit volume of metal removed, in.-lb per cu in.

$\alpha=$ effective rake angle of tool as measured in a plane perpendicular to its cutting edge, deg

$\phi=$ shear angle; angle between shear plane and surface being generated, deg

FIGURE 4.3. The Orthogonal Cutting Model (Ref. 5) 


$$
u=\frac{w_{f}}{w_{n}}=\frac{\sin \phi \cos \phi-\left(f_{t} / f_{c}\right) \sin ^{2} \phi(\cot \phi+\tan (\phi-\alpha))}{\left(\left(f_{t} / f_{c}\right) \cos \alpha+\sin \alpha\right)((\sin \phi / \cos (\phi-a))}
$$

with the shear angle $\phi$ defined as:

$$
\phi=\tan ^{-1} \frac{b \cos \alpha}{1-b \cos \alpha}
$$

where the new variable $b$, the cutting ratio, is defined as the ratio of the chip thickness to the depth of cut.

In the above expression for $u_{c}$, only one variable, the rake angle of the tool, is known. All other variables must be determined experimentally. Selected calculated values for $u_{c}$ are shown in Table 4.2 for various cutting force $f_{t} / f_{c}$ ratios and rake angles at a cutting ratio b equal to 2 . As seen, changes in the ratio a closely parallel those of $f_{t} / f_{c}$ but are not too sensitive to shanges in the rake angle.

To 1 first approximation, most cutting operations have an $f_{t} / f_{c}$ ratio of about ons-half (Ref. 6). Further, to achieve optimum surface finish and continuous ship formation, the cutting ratio should be high, ranging in value from 1.5 to 3.0 (Ref. 3). The most commonly used turning, drilling, and milling tools have positive rake angles that are relatively small, from 0 to 15 degrees (Refs. $2,3,4,7$ ). Thus, using an $f_{t} / f_{c}$ ratio of 0.50 , a cutting ratio b of 2 , and a rake angle of 10 degrees, a calculated value for the metalworking efficiency ratio $u_{c}$ is 0.5 . In this model, this value for $u_{c}$ is used for all metalcut:ing operations.

The effect of surface modified tools is usually seen as a percentage decrease in the cutting force. From the definition of $u$, such a percentage decrease translates directiy into an equal drop in the efficiency ratio. 
TABLE 4.2. Calculate Values for Cutting

Efficiency $u$ as a Function

of $f_{t} / f_{C}$ and the Rake Angle a

$\begin{array}{crr}\frac{\mathrm{ft} / \mathrm{fc}}{0.6} & \frac{\mathrm{a}}{0} & \frac{\mathrm{u}}{0.66} \\ & 5 & 0.61 \\ & 10 & 0.57 \\ & 15 & 0.55 \\ 0.5 & 0 & 0.6 \\ & 5 & 0.54 \\ & 10 & 0.51 \\ & 15 & 0.49 \\ 0.4 & 0 & 0.5 \\ & 5 & 0.46 \\ & 10 & 0.43 \\ & 15 & 0.41 \\ 0.3 & 0 & 0.4 \\ & 5 & 0.31 \\ & 10 & 0.31 \\ & 15 & 0.31\end{array}$

4.2.3.2 The Metalforming Efficiency Ratio $u_{f}$

Unlike metalcutting, metalforming operations cannot be described by a single mathematical model. An efficiency ratio must be assessed for each metalforming operation.

Shearing. The thickness of the sheet metal used in shearing ranges from a few hundredths of an inch to an inch. For thin sheets, friction does not have a significant effect on the shearing load force (Ref. 8). For thick sheets, force relations similar to those found in metalcutting might apply (Refs. 9, 10). Most sheet metals that are sheared are thin. Thus, for shearing, an efficiency ratio equal to zero is used. 
Punching. The mathematical modeling of punching forces is difficult because the interactions among the forces are complex. Even in a simple punching operation such as the radial drawing of cups, the loading force has three components: an ideal load to deform the metal, a frictional load to overcome friction, and an ironing load to thin the cup wall. Further, each of these loads has several subloads. The ideal load consists of a radial drawing load, a load to stretch form the blank over the die radius, a load to draw the metal through the throat of the die, and a load to stretch the form over the punch radius. An exact and complete model of the punching process is not yet available, although many attempts have been made, notably by Chang and Swift (Ref. 11).

It is possible, however, to obtain a first estimate of the efficiency ratio in punching from experimental results. Following Hosford, the ratio of the redundant work to the total work in cup drawing is approximately 0.74-0.79, where redundant work is also defined to include friction (Ref. 12). Assuming that recundant work is nearly equal to frictional work, an efficiency ratio of approximately 37 percent would be derived. This figure compares with those obtained by Freeman and Leeming, who determined that the frictional component of the punch load in the ironing of thin walled metal cups is approximately 30 percent (Ref. 13), and with the generalization of Blazynski, who found that friction accounts for 10-20 percent of the force requirement in most metalforming operations (Ref, 14). Using these results, this study assumes an efficiency ratio in punching of 30 percent.

In many punching operations, such as drawing, doubling the coefficient of friction also doubles the contribution of friction to the load force (Ref. 15). This study, therefore, assumes that the percentage decrease (or increase) in the efficiency ratio is the same as that of the coefficient of friction.

Bending and Forming. The friction component of the load force in bending operations such as rotary draw bending and roll hending is negligible because tool-workpiece contact is minimal. On the other hand, compression bending and stretch forming, as well as most tube forming operations (e.g., tube flaring, 
flanging, beading, curling, expanding, reducing, and swaging), rely on frictional forces to shape the metal. In other words, a certain amount of friction is desirable in these operations (Ref. 16). Therefore, this study does not. consider bending and forming machines.

Forging and Pressing. Under slipping friction conditions, the forging pressure is given by (Ref. 16):

$$
P=\sigma_{0} \exp \left[\left(\frac{2 \mu}{h}\right)(a \pm x)\right]
$$

while the forging pressure if friction is not present is simply the yield stress of the material:

$$
P_{\text {ideal }}=\sigma_{0}
$$

In these equations, the symbols are:

$\mu=$ coefficient of friction between the die and the workpiece

$a=$ half width of the workpiece $(\mathrm{mm})$

$h=$ height of the workpiece $(\mathrm{mm})$

$x=$ position along the $x$-axis; $x=0$ is at the vertical centerline

The forging pressure is maximum at the center when $x=0$ and is minimum at the edges when $x=a$. To simplify the calculation, a mean pressure $\left(P_{\text {mean }}\right)$ can be used, where:

$$
P_{\text {mean }}=\sigma_{0}\left(1+\frac{\mu a}{h}\right)
$$

since it is true that: $\left(2 \frac{u}{h}(a \pm x) \approx 1+2 \frac{u}{h}(a \pm x)\right)$

when $2 \frac{u}{h}(a \pm x)$ is less than 1 , which is always true. 
The efficiency ratio in forging can be written as:

$$
u=\frac{P_{\text {mean }}-P_{\text {idea }}}{P_{\text {ideal }}}=\mu \frac{h}{a}
$$

This study uses the simple case where $a=h$, so that the efficiency ratio is equal to the coefficient of friction.

Other Forming Operations. Rolling has been considered by PNL as part of its study on tribological sinks in the primary metals industries. This study, therefore, does not include rolling even though it is probably the most common metal processing operation (most metals are usually cast and rolled after refining).

Wire drawing machines make up only 2 percent of all metalforming machines. They can he omitted without unduly affecting the results of the study.

Extrusion is a specialized pressing operation. In effect, in extrusion, a metal cylinder is forced through a die orifice by means of a ram (direct extrusion), or a hollow ram is forced into the metal cylinder so that metal flows through the die and into the ram (indirect extrusion). Extrusion machines are implicitly included in the presses and forges group in this study, and the same functional relation between the coefficient of friction and the efficiency ratio is used to model extrusion. Such a procedure is justifiable because it can be snown that the efficiency ratio in extrusion is proportional to the coefficient of friction in the same manner as that found for forging. Specifically, in extrusion:

$$
u=\frac{2 L}{d_{1}}
$$

where:

$$
\begin{aligned}
L & =\text { length of the cylinder } \\
d_{1} & =\text { original diameter of the cylinder. }
\end{aligned}
$$




\subsubsection{Other Components of the Model}

The friction tribological sink $T_{f}$ is:

$$
T_{f}=I+E
$$

The wear tribological sink $T_{w}$ is:

$$
T_{w}=\sum_{a, j} a_{a} m_{a, j}
$$

where:

$$
\begin{aligned}
q_{a} & =\text { embodied energy of alloy a } \\
m_{a, j} & =\text { consumption of tool alloy a in industry } j \text { (ton/year). }
\end{aligned}
$$

The tribological sink $E_{S}$ in metalworking is:

$$
E_{S}=T_{f}+T_{w}
$$

The energy savings due to friction reduction $\left(I_{f}\right)$ from using surface modification technologies is:

$$
\begin{aligned}
\Delta I & =I\left(u_{2}\right)-I\left(u_{1}\right) \\
& =\sum_{i, j} n_{i, j} p_{i} h s\left(\frac{1-e}{1+u_{2}}\right) u_{2}-\sum_{i, j} n_{i, j} p_{i} h s\left(\frac{1-\frac{e}{1}-u_{1}}{1}\right) u_{1} \\
& =\sum_{i, j} n_{i, j} p_{i} h s(1-e) \frac{\left(u_{2}-u_{1}\right)}{\left(u_{2}+1\right)\left(u_{1}+1\right)}
\end{aligned}
$$

where $u_{2}$ and $u_{1}$ are the efficiency ratios both before and after the introduction of surface modified tools.

The energy savings due to wear reduction from using surface modification technologies, $T_{W}$, are: 


$$
\Delta T_{w}=\sum_{a, j} a_{a} m_{a, j}\left(\frac{v}{v+1}\right)
$$

where $\Delta$ is the average increase in tool life (in percent) attributable to the use of surface modified tools.

The energy savings due to the use of surface modification technologies in metalworking are:

$$
\Delta E_{s m}=\Delta I_{f}+\Delta I_{W}
$$

\subsection{DATA USED IN THE MODEL}

The following data are needed to implement the model: the number of machine tools used in the Inited States, rated horsepower of the main motor of machine tools, friction coefficients with and without surface modified tools in metalworking, efficiency of spindle drive, and consumption of alloys in the metalworking industries.

\subsubsection{The Machine Tool Data}

The 13th American Machinist Inventory of Metalworking Equipment 1983 is the prirary source for the number of machine tools in the United States (see Section 3.2). This section concentrates on how the data are used in this model.

\subsubsection{Metalcutting Machines Included in the Study}

Metalcutting machines are classified according to the machining operation involved: turning, milling, broaching, and cutoff and sawing. In the turning machine group are numerically controlled (NC) turning machines, non-numerically controlled (Non-NC) turning machines, NC and Non-NC boring machines, and machining centers, which are essentially multipurpose machines that can turn, bore, drill, or mill. The milling group includes NC and Non-NC milling machines and gear cutting and finishing machines, which are basically specialized milling devices. The drilling group includes NC and Non-NC drilling machines and tapping machines. The broaching groups include broaching machines 
of all types. The cutoff and sawing group includes hacksaw, circular cutoff sawing, bandsaws, contour sawing and filing, and all other cutting machines except those using abrasive wheels. Table 4.3 gives the type and number of metalcutting machines considered in this study.

\subsubsection{Metalforming Machines Included in the Study}

Metalforming machines are classified in three major groups: punching and shearing, bending and forming, and presses and forges. The punching and shearing group includes all NC and Non-NC punching and shearing machines. The bending and forming group includes NC and Non-NC bending machines such as press brakes (mechanical or hydraulic), bending rolts, rotary bending and forming, and ram and press bending machines. The press and forges group includes all mechanical, hydraulic, or pneumatic presses and forging machines such as headers and upsetters, swaging machines and expanders, and forging presses. Table 4.4 lists the types and number of the machines considered in this study.

\subsubsection{The Main Spindle Drive Horsepower Rating}

DHR, Inc., compiled data on the horsepower rating of the main spindle drive of machine tools by surveying existing equipment. The primary data sources were the manufacturers' product specification sheets. The manufacturers were contacted by ma $i 1$, by telephone, and directly at the International Machine Tool Show (IMTS) held in Chicago early in September, 1984.

Spindle drive horsepower data are important and useful as upper bound checks on the calculated horsepower requirements in metalcutting and as the raw or primary data for estimating energy consumption by metalforming machines. For these machines, the weighted average horsepower of the main drive motor was calculated using the number of machines as the weighting factor. Appendix $C$ gives the spindle drive horsepower of the metalworking machines surveyed. Table 4.5 gives the calculated horsepower for the metalcutting machines considered in this study, and Table 4.6 gives their materials averaged horsepower. 4.3.3 Coefficient of Friction Data for Metalforming Machines

Metalworking machines are usually operated only under lubrication. The coefficient of friction under lubricated conditions can vary widely from one 
TABLE 4.3. Metalcutting Machine Tools Considered in this Study

\begin{tabular}{|c|c|c|c|c|c|c|c|c|c|}
\hline \multirow[b]{2}{*}{ Machine Type } & \multicolumn{9}{|c|}{ Industry Group (1) } \\
\hline & SIC 25 & $\$ 1 C 33$ & 51034 & SIC 35 & SIC 36 & $\operatorname{sic} 37$ & $\operatorname{SIC~} 38$ & SIC 39 & TOTAL \\
\hline 1. TURNING MACHINE GROUP & 982 & 20904 & 85327 & 191914 & 42330 & 59868 & 24123 & 8834 & 435208 \\
\hline - NC Turning Machines & 46 & 842 & 4348 & 18592 & 2677 & 4922 & 1538 & 387 & 33352 \\
\hline - Non-NC Jurning Machines & 811 & 17390 & 75235 & 136490 & 34652 & 39818 & 20362 & 7569 & 332327 \\
\hline - NC Boring Machines & 25 & 271 & 500 & 2935 & 182 & 907 & 106 & 138 & 5064 \\
\hline - Non-NC Goring Machines & 74 & 2087 & 3592 & 19980 & 3065 & 10094 & 877 & 693 & 40462 \\
\hline - Machining Centers & 26 & 350 & 1652 & 13917 & 2644 & 4127 & 1240 & 47 & 24003 \\
\hline 2. ORILLING MACHINE GROUP & 2606 & 18528 & 68675 & 125146 & 44179 & 40497 & 21686 & 7971 & 329288 \\
\hline - NC Drilling Machines & 58 & 261 & 1121 & 4205 & 1150 & 718 & 227 & 253 & 7993 \\
\hline - Non-NC trilting Machines & 2271 & 14873 & 54602 & 109924 & 37116 & 36191 & 19200 & 7276 & 281453 \\
\hline - Tapping Machines & 257 & 2620 & 8085 & 7989 & 5121 & 2007 & 1669 & 391 & 28139 \\
\hline - Threadirg Machines & 20 & 774 & 4867 & 3028 & 792 & 1581 & 590 & 51 & 11703 \\
\hline 3. DRILLING MACHINE GROUP & 1181 & 9610 & 39471 & 128121 & 27206 & 42089 & 15317 & 6247 & 269242 \\
\hline - NC MiTl'ng Machines & 45 & 433 & 1676 & 7876 & 1983 & 2145 & 1132 & 639 & 15929 \\
\hline - Non-NC Milling Machines & 1099 & 8658 & 36102 & 103072 & 23862 & 27199 & 12907 & 5580 & 218479 \\
\hline - Gear Cutting Machines & 37 & 519 & 1693 & 17173 & 1361 & 12745 & 1278 & 28 & 34834 \\
\hline 4. BROACF ING MACHINE GROUP & 33 & 652 & 2624 & 6825 & 821 & 5197 & 233 & 120 & 16505 \\
\hline 5. SAWINC MACHINE GROUP & 2259 & 10458 & 40115 & 56807 & 18911 & 21371 & 8587 & 6999 & 169107 \\
\hline
\end{tabular}

11) \$1C Codes:

25: Furniture and Fixtures

33: Primary Metal Industries

34: Fabricated Metal Products

35: Machinery, Except Electrical

36: Electric and Electronic Equipment

37: Transportation Equipment

38: Instruments and Related Products

39: Miscellaneous Manufacturing Industries 
IABLE 4.4. Metalforming Machine Tools Considered in this Study

\begin{tabular}{|c|c|c|c|c|c|c|c|c|c|}
\hline \multirow[b]{2}{*}{ Machine Type } & \multirow[b]{2}{*}{ SIC 25} & \multirow[b]{2}{*}{ SIC 33} & \multirow[b]{2}{*}{ SIC 34} & \multicolumn{3}{|c|}{ Industry Group (1) } & \multirow[b]{2}{*}{ SIC 38} & \multirow[b]{2}{*}{51039} & \multirow[b]{2}{*}{ TOTAL } \\
\hline & & & & SIC 35 & SIC 36 & Sic 37 & & & \\
\hline 1. PUNCHING AND SHEARING GROUP & 1854 & 2924 & 26139 & 19571 & 9565 & 7222 & 3296 & 2015 & 72586 \\
\hline - NC Punching and Shearing & 166 & 95 & 2490 & 1290 & 1013 & 373 & 368 & $42 B$ & 6223 \\
\hline - Non-NC Punching and Shearing & 1688 & 2829 & 23649 & 18281 & 8552 & 6849 & 2928 & 1587 & 66363 \\
\hline 2. BENDJNG AND FORMING GROUP & 4487 & 3177 & 30196 & 19945 & 8432 & 9591 & 2569 & 1473 & 79870 \\
\hline - NC Bending and Forming & 197 & 145 & 989 & 493 & 247 & 428 & 71 & 15 & 2585 \\
\hline - Non-NC Bending and Forming & 4290 & 3032 & 29207 & 19452 & 8185 & 9163 & 2498 & 1458 & 77285 \\
\hline 3. PRESSES AND FORGES GROUP & 9040 & 16380 & 114356 & 46479 & 45114 & 32316 & 11570 & 14279 & 289534 \\
\hline - Mechanical Presses & 8508 & 7187 & 89051 & 29289 & 29544 & 19010 & 6376 & 10008 & 198973 \\
\hline - Hydraulic Presses & 283 & 6422 & 10494 & 13300 & 9131 & 9712 & 2530 & 1420 & 53292 \\
\hline - Preumatic Presses & 159 & 567 & 3512 & 2309 & 5592 & 1557 & 2563 & 1397 & 17656 \\
\hline - Forges & 90 & 2204 & 11299 & 1581 & 847 & 2037 & 101 & 1454 & 19613 \\
\hline
\end{tabular}
(1) SIC Codes:
25: Furniture and Fixtures
33: Primary Metal Industries
34: Fabricated Metal Products
35: Machinery, Except Electrical
36: Electric and Electronic Equipment
37: Transportation Equipment.
38: Instruments and Related Products
39: Miscellaneous Manufacturing Industries 
TABLE 4.5. Cutting Conditions and Derived Motor Horsepower

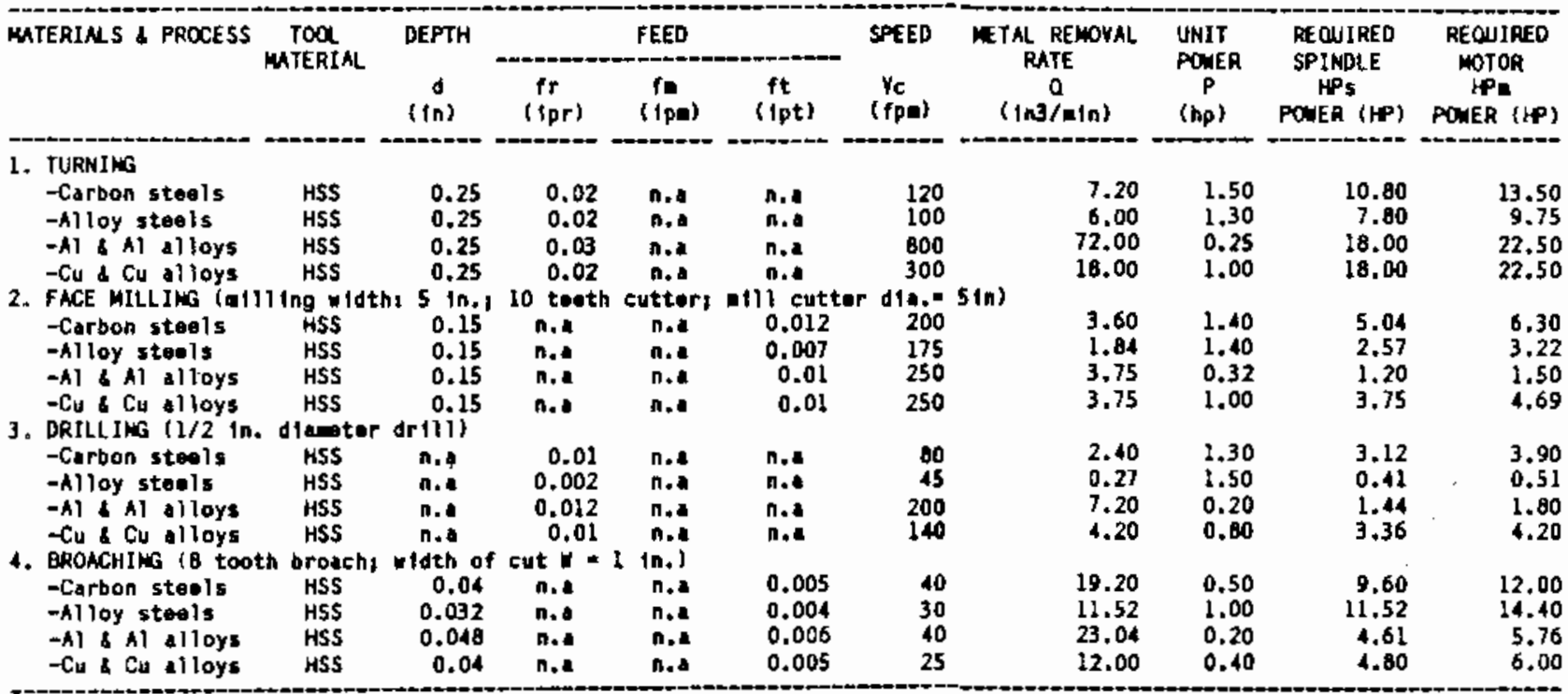

NOTES, A) Matal removal rato and horsepowor equationel

- Turning : $Q=12 \times d \times f r \times Y c$

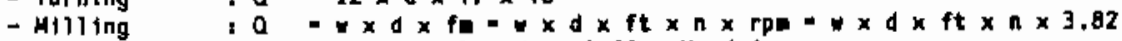

- Orilling i $a=3.1416 \times 0 \times$ fr $\times 3.82 \times V_{c} / 4$

- droeching t $Q=12 \times \gamma c \times$ ft $\times n=12 \times V_{c} \times \mathrm{dt}$

- Required porer, HPs $=Q \times P$ (at spindle)

- Roquirad pover. HPa $=Q \times P / E$ (at cotor)

- Orflling $\mathrm{rpa}: 3.82 \times \mathrm{Yc} / \mathrm{O}$

rhares $Q=$ motal removaj rate, cubic inches per alnute

d. depth of cut. inches

dt = total stock remped per stroke, inch. For Broaching, dt = chip load

fr - foed, Inches por rovolution

Yc - cutting speed, foet por ainute

- Width of cut, inchos

fa. foed rate, inchas por inute. For arflling, fo = fr $\times$ rose $=$ fr $\times 3.8$

ft - foed rate, inches por tooth

$n$ - number of teeth in cuttor

rpe. rovolution per minute of rork or cutter

D - of aester of ortll or alliling cutter, Inches

HPs - required horsepower at epind l*, hp

$P_{\text {n }}$ * requifed hor sopover at motor, hp

$E$. off fetency of spindle drive, wout bas

$P$ - unit power, horsopower per cubic inch per alnuto

a) HS! = high speed steel

machine to another and from location to location at the tool-workpiece interface. For example, the coefficient of friction in rolling is maximum near the center of the contact zone.

Coefficient of friction data for many metalforming machine and lubrication conditions have been compiled by Schey (Ref. 6). They are given in Table 4.7. In this study, the arithmetic average of these values is used. 
TABLE 4.6. Materials Averaged Motor Horsepower, by Operation and Industry

\begin{tabular}{|c|c|c|c|c|c|c|c|c|}
\hline \multirow[t]{2}{*}{ PROCESS } & \multicolumn{8}{|c|}{$\begin{array}{l}\text { MATERIALS AVERAGED MOTOR HORSEPOWER } \\
\text { BY INDUSTRY }(\mathrm{hp})^{(1)}\end{array}$} \\
\hline & SIC 25 & SIC 33 & $51 C 34$ & SIC 35 & SIC 36 & SIC 37 & SIC 38 & SIC 39 \\
\hline 1. Turning & 14.20 & 22.50 & 13.95 & 14.08 & 15.04 & 13.89 & 13.02 & 10.02 \\
\hline 2. Drilling & 3.64 & 3.34 & 3.54 & 3.35 & 3.50 & 3.51 & 1.81 & 0.76 \\
\hline 3. Milling & 5.79 & 3.55 & 5.76 & 5.51 & 5.47 & 5.75 & 3.97 & 3.44 \\
\hline 4. Broaching & 11.56 & 5.91 & 11.68 & 11.58 & 10.95 & 11.72 & 12.24 & 14.22 \\
\hline
\end{tabular}

(1) SIC Codes:

25: Furniture and Fixtures

33: Primary Metal Industries

34: Fabricated Metal Products

35: Machinery, Except Electrical

36: Electric and Electronic Equipment

37: Transportation Equipment

38: Instruments and Related Products

39: Miscellaneous Manufacturing Industries

The effects of surface modification technologies on the coefficient of friction were discussed in Section 4.3.3.

\subsection{METALWORKING ALLOY CONSIMPTION DATA}

The U.S. Bureau of the Census provides data on the consumption of major engineering alloys in the 1977 Census of Manufacturers (Ref. 17). For this study data on the consumption of carbon steels, alloy steels, copper and copper alloys, and aluminum and aluminum alloys were needed. Such data expressed as a percentage of the total tonnage consumed in each industry group are shown in Tables 4.8 and 4.9 .

The metalforming and metalcutting tool manufacturers are SIC 35441 and SIC 35451, respectively. Data on the tonnage of alloys used by these industries are not available, but estimates can be made using Census Bureau data on values 
TAHIf 4:l: fypical Metalworking loefficients

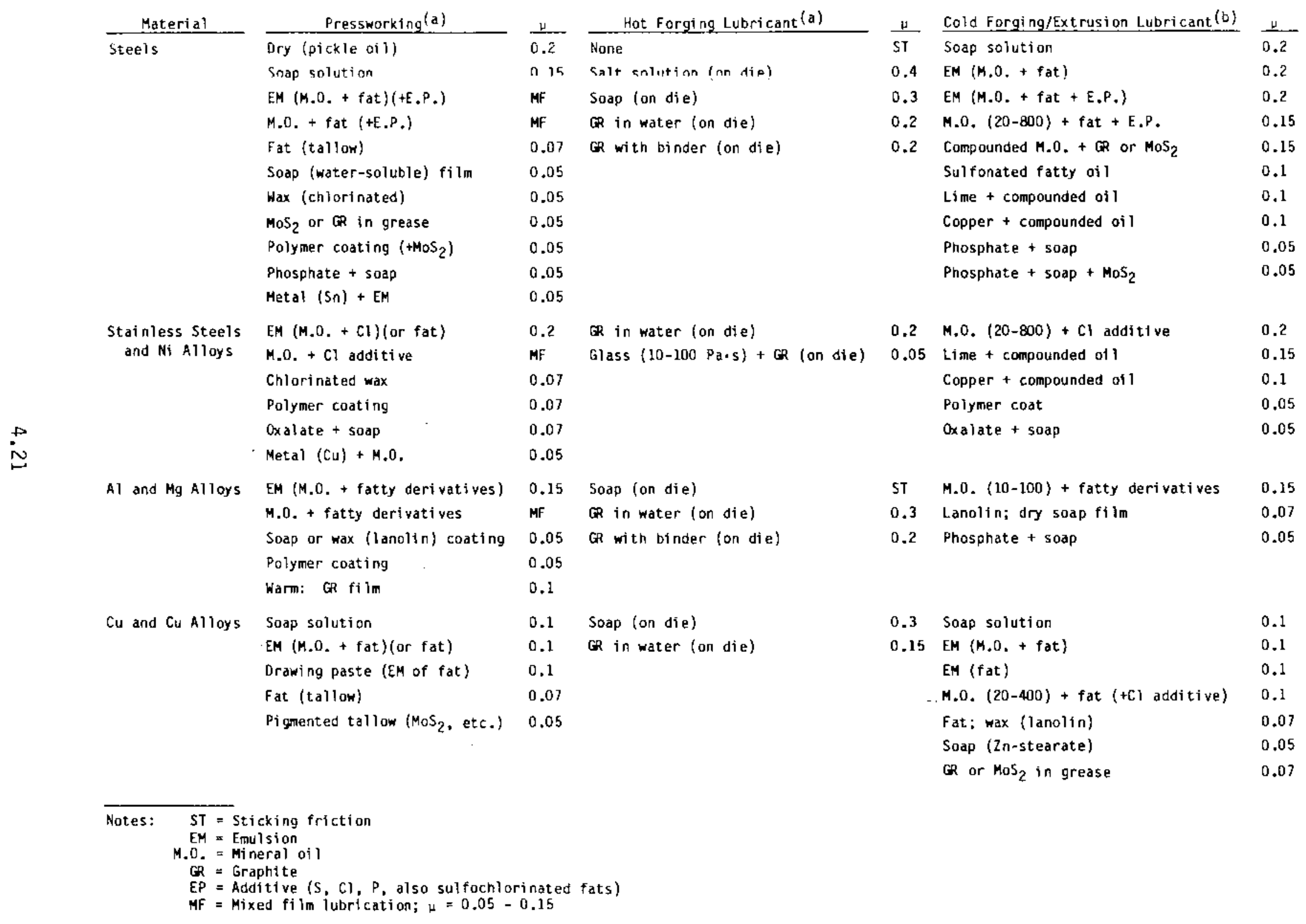


TABLE 4.8. Alloy Consumption by Metalworking Industries, 1977

Materials Consumed

Cut Form SIC 25 SIC 33 SIC 34 SIC 35 SIC 36 SIC 37 SIC 38 SIC 39 Total

1 Steel Mill Shapes and Forms

1.1 Carbon Stee 1

- Bars and shapes except concrete

retinforcing bars

- Sheet and strip

- Plates

- Structural shapes

- Wire and wire products

- All other mitl shapes and forms

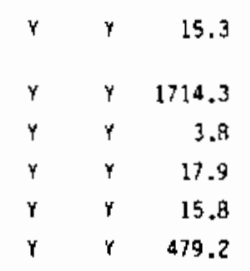

1.2 Alloy Stee

- Rar and bar shapes except stainless

- All other mill shapes and forms except stainless

- Stainless steei

- Sheet and strip

- All other stainless steel mill shapes and forms

2 Copper and Copper-Base Alloy Mill Shapes and Forms

2.1 Brass Wire for Electrtca? Conduction

2.2 Insulated wire and Cable (copper content)

?.3 Rrass !4ill Shapes

- Rod, bar and mechanical wire

- plate, sneet, and gtrip

- Pipe and tube

3 Aluminum and ATuminum-8ase Alloy Mill Shapes and forms

3.1 Sheet, plate and Foil

3.2 Extruded Shapes

3.3 all other Aluminum Mt? Shapes and Forms

4 Selected Castings and Fargings

4.1 Castings--Rough and Semifinished

- Iron-ogrey and malleable

- Steel

- Aluminum and aluminum base alloy

- Copper and copper-base alloy

4.2 Forgings

- Iron and steel

- Aluminum and aluminum-base

- Metal power

$5 \quad$ Dig Iron and Nonferrous Refinery Shapes

5.1 Pig Iron

5.2 Nonferrous Refinery Shapes

- Copper and copper-base alvoy

- zinc and zinc-base alioy

- Aluminum and aluminum-base atloy

Legend: $Y=$ Yes; $N=$ No; $L$ = Little

$\begin{array}{rrrrrrr}4098 & 2428.2 & 451.2 & 1944.7 & 23 & 1.8 & 8962.2 \\ 18514.7 & 3448 & 4242.3 & 9411.1 & 95.4 & 6.7 & 37522.5 \\ 3350.7 & 3102.2 & 121.4 & 2231.2 & 6.3 & & 8815.6 \\ 3020.1 & 1030.4 & 139.1 & 773.2 & & & 4980.7 \\ 1949.2 & 210.5 & 362 & 212.4 & 6 & & 2755.9 \\ 9426.6 & 1221.4 & 805.7 & 811.4 & 44 & 446.3 & 13234.6 \\ & & & & & & \\ 1274.5 & 786.1 & 12 & 852 & & & 2953.6 \\ 1240.9 & 720.4 & 445.8 & 391.5 & 271 & 71.3 & 3140.5 \\ & & & & & & \\ 335.1 & 137.7 & 59.9 & 1.58 .3 & 29.1 & 18.8 & 738.9 \\ 243.2 & 148.8 & 28.2 & 52 & 13.2 & 17.4 & 527.2\end{array}$

$\begin{array}{ccrrcccc}329 & 4 & 18.4 & 102.3 & 27 & 6.2 & 0 & 486.3 \\ 33.5 & 3.2 & 65.9 & 227.3 & 99.3 & 4.2 & & 433.4 \\ 0 & 476.4 & 91.6 & 220.2 & 183 & 27.5 & & 990.7 \\ 55.9 & 204.9 & 168.6 & 162.8 & 165.9 & & & 758.1 \\ 0 & 152.5 & 232.8 & 44.5 & 35.2 & & 0 & 465.1\end{array}$

$\begin{array}{rrrrlrrl}30.4 & 0 & 3313.7 & 372.1 & 246.2 & 638.7 & 4.1 & 4605.2 \\ 98.3 & 0 & 735.2 & 162.2 & 146.9 & 312.1 & 17.3 & 1472 \\ 79.8 & 62 & 661.7 & 175.5 & 178 & 43.2 & 51.3 & 1251.5\end{array}$

$\begin{array}{lllllll}686.5 & 2580.6 & 209.1 & 5008.5 & 0 & 0 & 8484.7\end{array}$

$\begin{array}{lllllll}232.5 & 494.7 & 22.7 & 649 & 20.5 & 0 & 1419.4\end{array}$

$\begin{array}{lllllll}145.8 & 650.6 & 326.7 & 750.6 & 40.5 & 0 & 1914.2\end{array}$

$\begin{array}{llllll}114 & 89.3 & 31.5 & 12.4 & 13.4 & 260.6\end{array}$

$\begin{array}{llllllll}179.2 & 947.8 & 8 & 1695.3 & 0 & 0 & 2830.3\end{array}$

$\begin{array}{lllllll}8.8 & 0 & 0 & 174 & 0 & 0 & 182.8\end{array}$

$\begin{array}{lllllll}7257.6 & 77 & 80.8 & 0 & 48.5 & 1463.9\end{array}$

$\begin{array}{llllll}1907.8 & 69.9 & 25.3 & 11.6 & 0 & 2013.6\end{array}$

$\begin{array}{llllll}686.6 & 153 & 0 & 17.8 & 0 & 857.4\end{array}$

$\begin{array}{llll}5565.4 & 247 & 110.5 & 5922.9\end{array}$ 
TABLE 4.9. Industrial Metalworking of Major Al loys, by Percentage, 1977

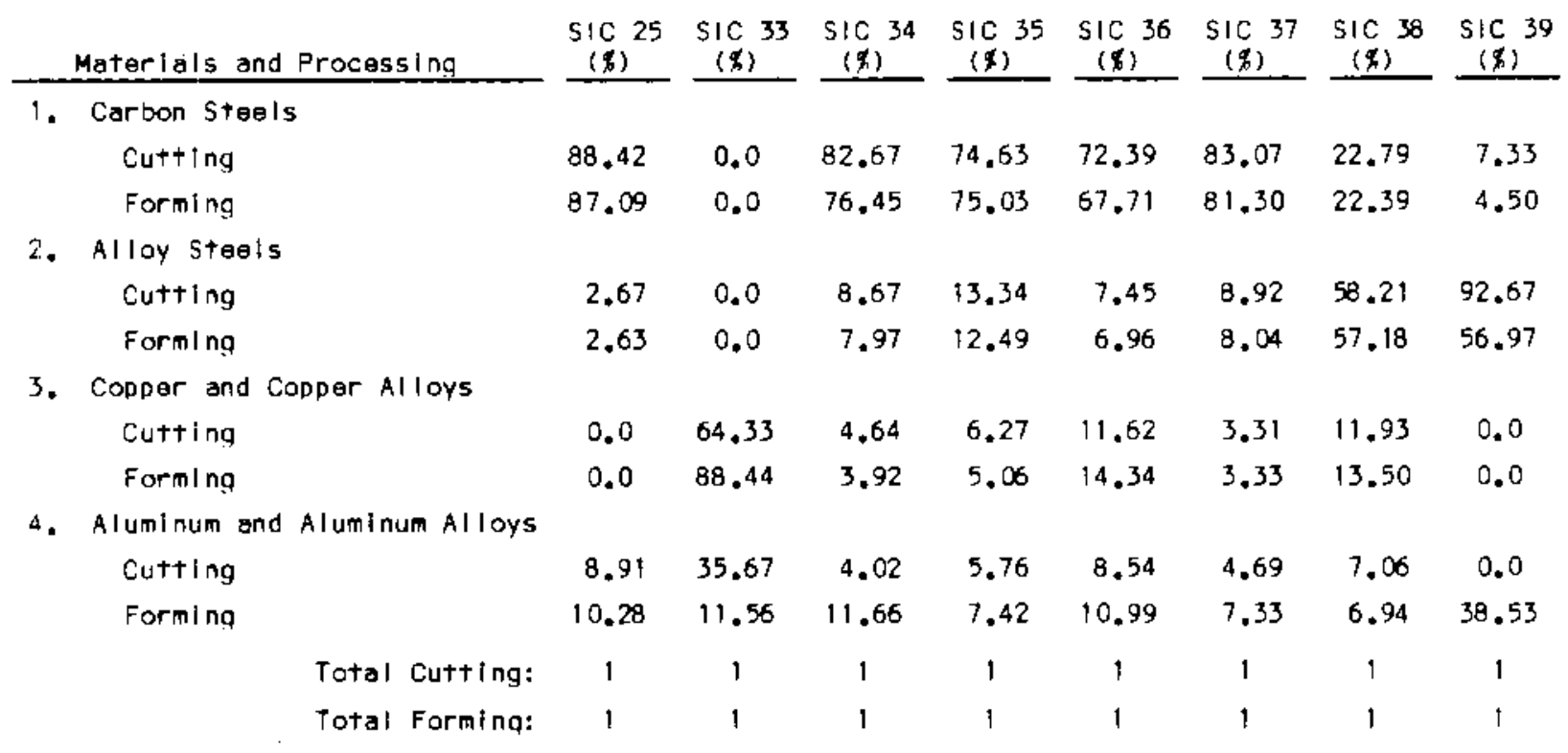

Source: (Ret. 17)

of product shipments and the tonnage of alloys consumed by the next larger industry classifications, SIC 3544 (Special Dies, Tool, Jig, and Fixtures) and SIC 3545 (Machine Tool Accessories). The estimating procedure assumes that the ratio of the tonnage of the alloys consumed by SIC 35441 (or SIC 35451) to that consumed by SIC 3544 (or SIC 3545) is equal to the ratio of their product shipment values. The estimates obtained are shown in Tables 4.10 and 4.11 . The figures probably underestimate actual consumption in view of the fact that they do not consider companies which manufacture their own forming tools. 
IABLE 4.10. Shipment values of Metalforming Accessories(1) (\$ million)

\begin{tabular}{|c|c|c|c|c|c|}
\hline \multicolumn{2}{|r|}{ Year } & $\begin{array}{c}\text { All } \\
\text { Accessories } \\
\mathrm{a} \\
\end{array}$ & $\begin{array}{c}\text { Working } \\
\text { Tools } \\
\text { b } \\
\end{array}$ & $\begin{array}{l}\text { Ratio } \\
b / a(x)\end{array}$ & $\begin{array}{c}\text { Annual } \\
\text { Growth Rate } \\
\text { of } b(\%)\end{array}$ \\
\hline \multirow[t]{8}{*}{ (A) 1} & Metal forming & & & & \\
\hline & 1982 & $N / A$ & $N / A$ & & \\
\hline & 1981 & 6975.2 & 4248.5 & 60.91 & 17.47 \\
\hline & 1980 & 6165.3 & 3616.7 & 58.66 & 1.16 \\
\hline & 1979 & 5732.6 & 3575.2 & 62.37 & 18.72 \\
\hline & 1978 & 5058.8 & 3011.5 & 59.53 & 16.82 \\
\hline & 1977 & 4450.2 & 2578.0 & 57.93 & \\
\hline & Average & Percentage: & & 59.88 & 13.54 \\
\hline \multirow[t]{8}{*}{ (B) } & Metalcutting & & & & \\
\hline & $1982^{(2)}$ & 3033.6 & 1744.2 & 57.50 & -21.29 \\
\hline & 1981 & 3854.0 & 2352.5 & 61.04 & 9.14 \\
\hline & 1980 & 3531.1 & 2199.4 & 62.29 & 10.16 \\
\hline & 1979 & 3205.4 & 2023.6 & 63.13 & 19.76 \\
\hline & 1978 & 2676.6 & 1651.7 & 61.71 & 19.55 \\
\hline & 1977 & 2238.9 & 1376.4 & 61.48 & \\
\hline & Average & Percentage: & & 61.19 & 9.33 \\
\hline
\end{tabular}

(1) Ref. 18 .

(2) Ref. 19. 
TABLE 4.11. Estimated Alloy Consumption for Metalworking Tools (1000 tons)

\begin{tabular}{|c|c|c|c|c|c|c|}
\hline \multirow[b]{2}{*}{ Alloy } & \multicolumn{2}{|c|}{$1977(a)$} & \multirow{2}{*}{$\begin{array}{l}1983(\mathrm{c}) \\
\text { Forming } \\
\text { Dies }\end{array}$} & \multicolumn{2}{|c|}{$1977(a)$} & $1983^{(e)}$ \\
\hline & $\begin{array}{l}\text { A11 Forming } \\
\text { Accessories }\end{array}$ & $\begin{array}{l}\text { Forming } \\
\text { Dies (b) }\end{array}$ & & $\begin{array}{l}\text { A11 Cutting } \\
\text { Accessories }\end{array}$ & $\begin{array}{l}\text { Cutting } \\
\text { Tools (d) }\end{array}$ & $\begin{array}{l}\text { Cutting } \\
\text { Tools }\end{array}$ \\
\hline Total & 212.50 & 127.25 & 272.61 & 92.60 & 56.66 & 121.39 \\
\hline Carbon Steel & 167.00 & 100.00 & 214.24 & 43.20 & 26.43 & 56.63 \\
\hline Alloy Steel & 42.30 & 25.33 & 54.26 & 48.70 & 29.80 & 63.84 \\
\hline Stainless Steel & 3.20 & 1.92 & 4.11 & 0.70 & 0.43 & 0.92 \\
\hline
\end{tabular}
(a) Ref. 17 .
(b) Calculated as $59.88 \%$ of all forming accessories.
(c) Calculated using an annual growth rate of $13.54 \%$
(d) Calculated as $61.19 \%$ of all cutting accessories.
(e) Calculated using an annual growth rate of $9.33 \%$. 


\section{REFERENCES}

1. Lyle, C. S. 1984. "A Proven Tooling System for Flexible Turning Machines." Paper presented at the 2nd Biennial International Machine Tool Technical Conference, September 5-13, 1984, Chicago, 111 inois.

2. Machinability Data Center. 1980. Machining Data Handbook, Vol.?. Netcut Research Associates, Inc., Cincinnati, Ohio.

3. Drozda, T. J., ed. 1983. Tool and Manufacturing Engineers Handbook-Volume 1: Machining. 4th Edition. Society of Manufacturing Engineers, Dearborn, Michigan.

4. Wilson, F. W., ed. 1959. Tool Engineers Handbook. 2nd ed. McGraw Hill, New York.

5. Donalson, C. et al. 1972. Tool Design. 3rd ed. McGraw Hill, New York.

6. Schey, J. A. 1983. Tribology in Metalworking, Friction, Lubrication and Wear. American Society for Metals, Metals Park, Ohio.

7. American Society of Metals. 1976. Metals Handbook--Volume 3: Machining. American Society for Metals, Metals Park, Ohio.

8. Schey, J. A., ed. 1972. Metal Deformation Processes, Friction and Lubrication. 2nd ed. Marcel Dekker, Inc., New York.

9. Rowe, G. W. 1967. Lubrication and Lubricant, ed. E. R. Braithwaite. E1sener Publishing Company, Amsterdam, New York.

10. Chang, A. and H. Swift. 1951. Proc. Inst. Mech. Engr. 165(1951):199.

11. Hosford, W. F. 1978. "Effect of Anisotropy and Work Hardening on Cup Drawing, Redrawing, and Ironing," in Fomability Analysis, Modeling and Experimentation. Metallurgical Society of the AIME, New York.

12. Freeman, R. and W. Leeming. 1983. "Ironing of Thin Walled Metal Cup: The Distribution of Punch Load," BISRA Report No. MW/E/53 (1953), cited by Hosford, W. F., in Metalforming: Mechanics and Metallurgy. Prentice Hall Publishers, Englewood Cliffs, New Jersey.

13. Blazynski, T. Z. 1976. Metalforming Tool Profiles and Flow. J. Wiley and Son, New York.

14. Rowe, G. W. 1978. Principles of Industrial Metalworking Processes. Edward Arnold Publishing, London, England. 
15. Kervitch, R. J. and R. K. Springborn. 1966. Cold Bending and Forming of Tubes and Other Sections. American Society of Tools and Manufacturing Engineers, Dearborn, Michigan.

16. Harris, J. B. 1983. Mechanical Working of Meta1: Theory and Practice. Pergamon Press, Oxford, New York.

17. U.S. Bureau of 1978. 1977 Census of Manufacturers. Government Printing Office, Washington, D.C.

18. U.S. Bureau of the Census, 1980-81 Annual Survey of Manufacturers. Government Printing Office, Washington, D.C.

19. U.S. Bureau of the Census. July 1984. 1982 Census of Manufacturers:

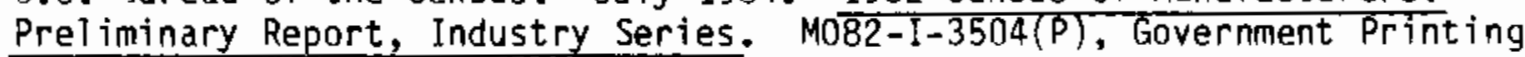
office, Washington, D.C. 



\subsection{RESULTS}

Estimates of the tribological sinks and the energy savings achievable using surface modified tools in metalworking are presented in this section.

\subsection{EFFECTS OF SURFACE MODIF ICATION TECHNOLOGIES IN METALCUTTING}

\subsubsection{The Frictional Sink in Metalcutting}

Frictional losses in metalcutting machines occur in spindle drive systems whenever a machine is running and at the tool point (i.e., the tool-workpiece interface) during productive cutting. This study estimates that frictional losses in all U.S. metalcutting machines during productive cutting only amount to 5,810 billion 8tu/year, 2,490 at the drive system and 3,320 at the too 1 point. Table 5.1 details the assumptions and calculations for these figures.

The origins of frictional losses by machine type and industry are shown in Figure 5.1 for those at the spindle drive and in Figure 5.2 for the tool point. Turning machines account for more than one-half of both types of frictional losses in all industries. Industry Group SIC 35, Machinery Except Electrical, 's responsible for nearly one-half of all losses, or 1,980 billion Btu/year.

\subsubsection{The Wear Sink in Metalcutting}

In Section 4.4 it was estimated that approximately 121,000 tons of steel were usec as raw materials for the manufacture of small cutting tools in 1983. Using 19.2 million 8tu/ton as the embodied energy in steels that are made from scrap in electric furnaces and are continuously cast, the wear sink is 2,323.2 billion Btu/year.

5.1.3 Er ergy Savings Achievable from Friction Reduction with Surface Modification Technologies

Assuming that surface modified tools can lower the efficiency ratio by 30 percent, as discussed in Section 2.2.4, approximately 739 billion Btu/year would result from full-scale use of these tools in metalcutting. Nearly onehalf of the savings would be realized in the turning machines groups, e.g., turning and boring machines and machining centers. From an industry 
TABLE 5.1. Metalcutting Energy Savings Model Inputs and Results

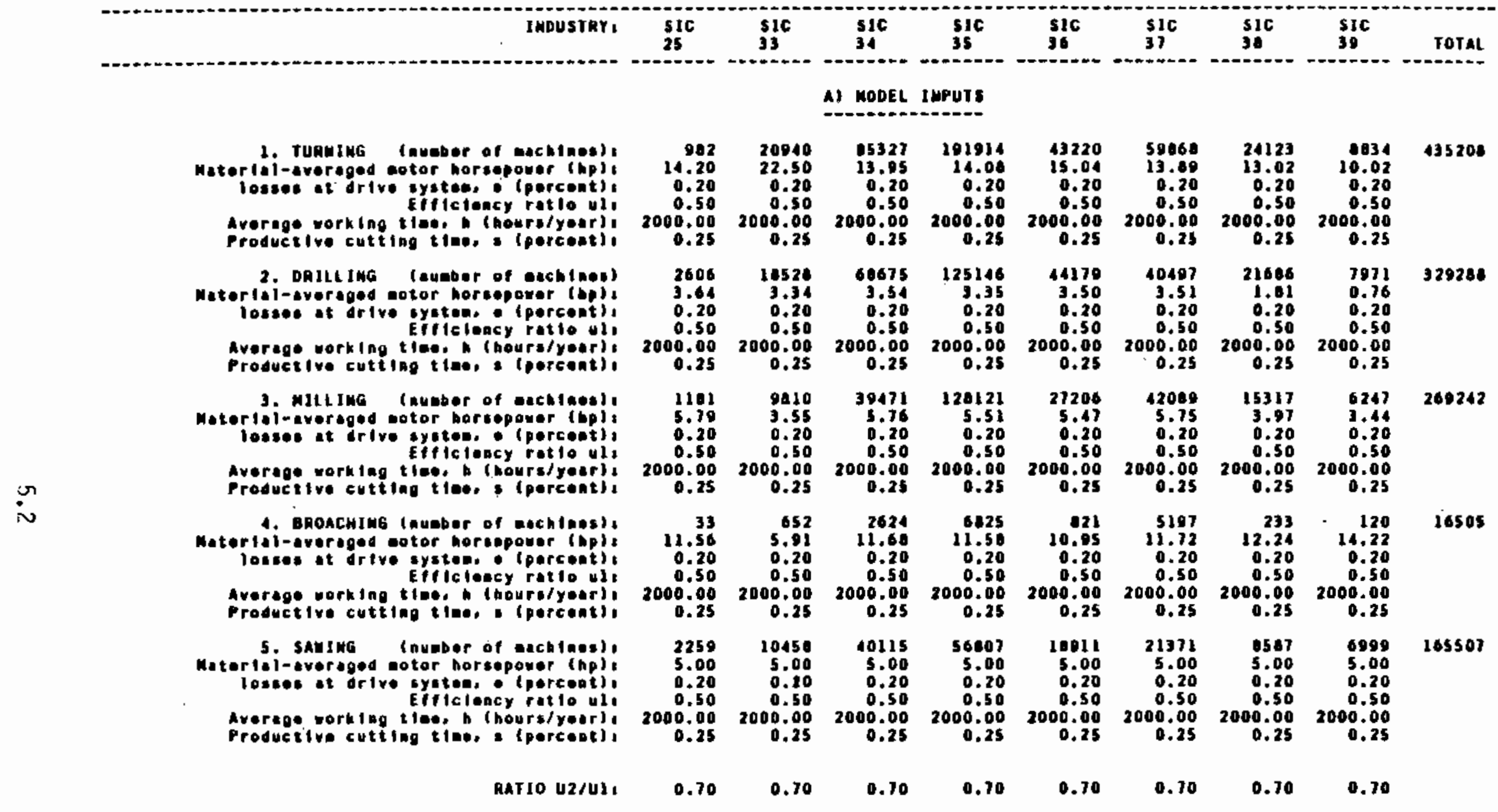

SIC Codes:

25: Furniture and Fixtures

33: Primary Metal Industries

34: Fabricated Metal Products

35: Machinery. Except Electrical

37: Transportation Equipment

38: Instruments and Related Praducts

36: Electric and Electronic Equipment

39: Miscellaneous Manufacturing Industries 
TABLE 5.1. (contd)

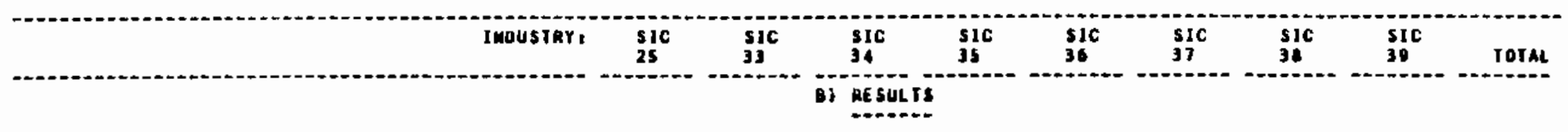

1. FRICTJOMAL SIMK AT MOTOR DRIVE SYSTEM

1.1. ALL MACHIME GROUPS

hp-hr/yoarf A.19E+06 6.23E+07 1.09E+0Q 4.10E+00 1.06E+00 1.36E+08 4.60E+07 1.53E+07 9.00E+08

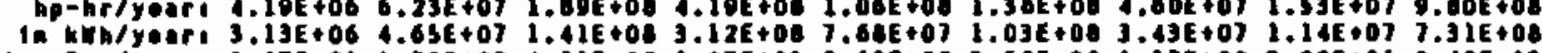

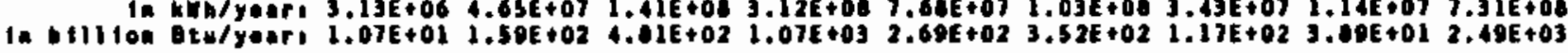

1.2. TURMZM MACHIME GROUP

-por nachine. In hp-hr/yeart $1.42 E+03 \quad 2.25 E+03 \quad 1.40 E+03 \quad 1.41 E+03 \quad 1.50 E+03 \quad 1.39 E+03 \quad 1.30 E+03 \quad 1.00 E+03$

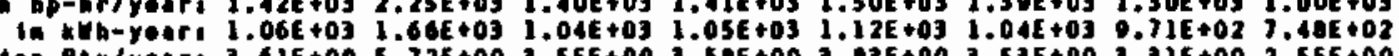

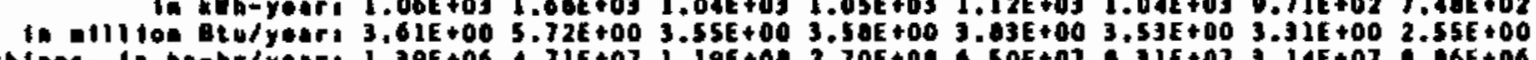

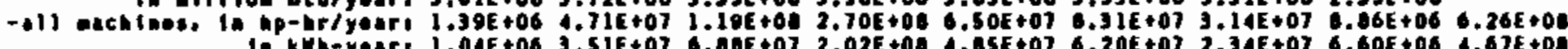

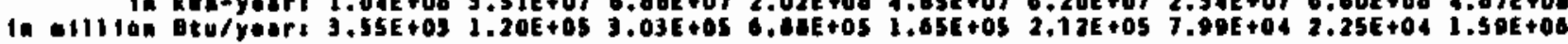

1.3. ORILLIMO WACHIME GROUP

-par wochine, in hp-hr/year, $3.64 E+023.34 E+02 \quad 3.54 E+023.35 E+023.50 E+023.51 E+021.01 E+02 \quad 7.55 E+01$ In $k$ Wh-yourd $2.71 E+02 \quad 2.49 E+02 \quad 2.64 E+02 \quad 2.49 E+02 \quad 2.61 E+02 \quad 2.62 E+02 \quad 1.35 E+02 \quad 3.63 E+01$

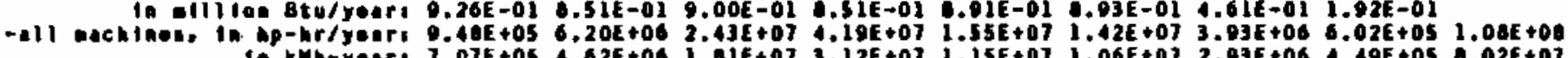

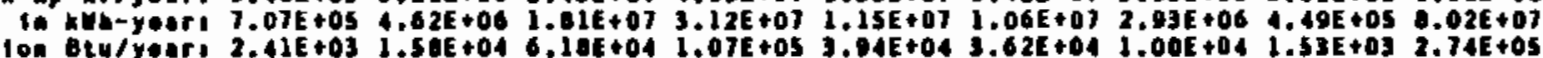

1.4. WILLING MACHIME GROUP

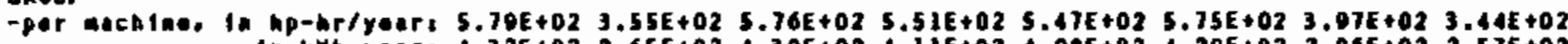

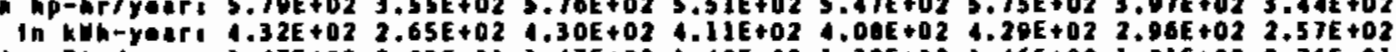

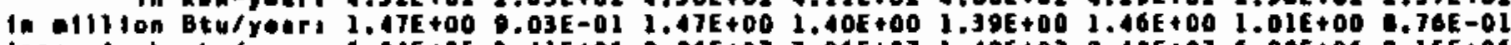

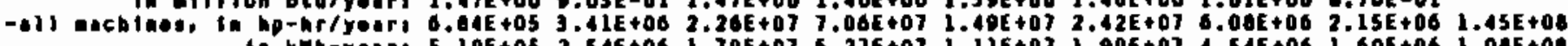

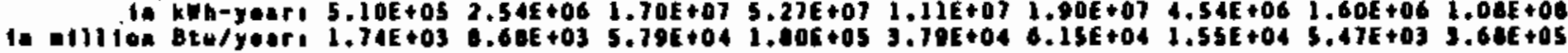

1.5. BROACHIMG MACHIHE GROUP

-per cachlae, In hp-hr/yeart $1.16 E+035.91 E+02 \quad 1.17 E+03 \quad 1.16 E+03 \quad 1.09 E+03 \quad 1.17 E+03 \quad 1.22 E+03 \quad 1.42 E+03$

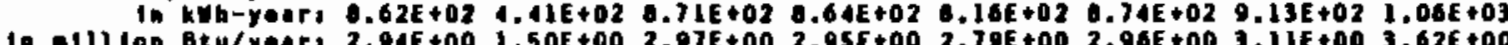

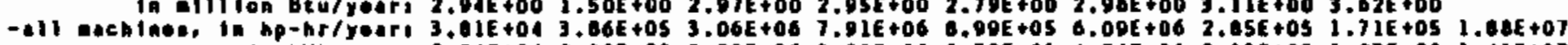

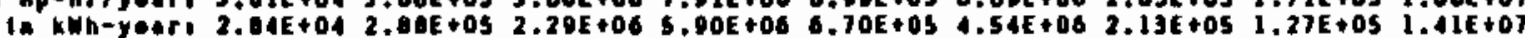

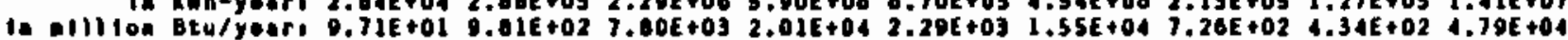

1.6. SAYING MACHIME GROUP

-por nochlne, Ia hp-hr/yotr 5.00E $+025.00 E+025,00 E+025.00 E+025.00 E+025.00 E+025.00 E+025.00 E+02$ In $=111$ In $k$ Wh-yeuri $3.73 E+02 \quad 3.73 E+023.73 E+02 \quad 3.73 E+023.73 E+023.73 E+02 \quad 3.73 E+02 \quad 3.73 E+02$

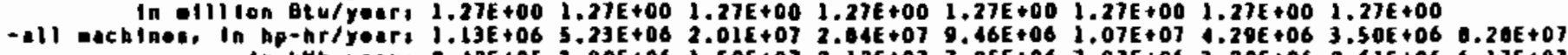

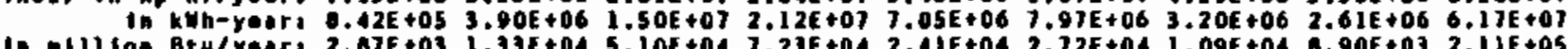


TABLE 5.1. (contd)

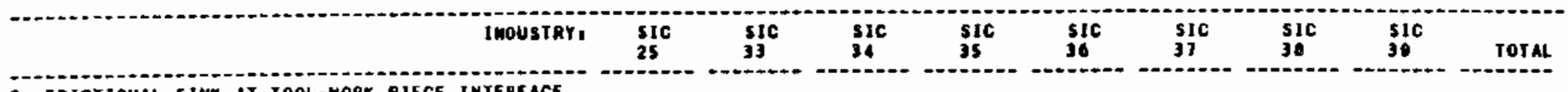

2. FRICTIONAL SIMK AT TOOL-WORK PJECE IMTERFACE

2.1. ALL MACHINE gROUPS

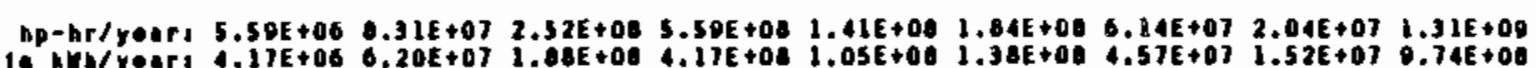

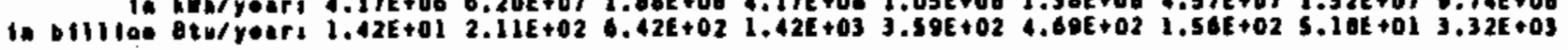

2.2. TUANIMG MACHIME GROUP

-por eachine, It hp-hr/yoart $1.09 E+03 \quad 3.00 E+03 \quad 1.06 E+03 \quad 1.60 E+03 \quad 2.00 E+03 \quad 1.05 E+03 \quad 1.74 E+031.34 E+03$

In KWH-yoari 1.41E+03 $2.24 E+03 \quad 1.30 E+03 \quad 1.40 E+03 \quad 1.49 E+03 \quad 1.30 E+03 \quad 1.30 E+03 \quad 0.97 E+02$

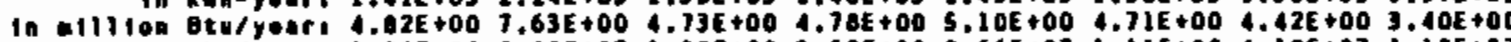

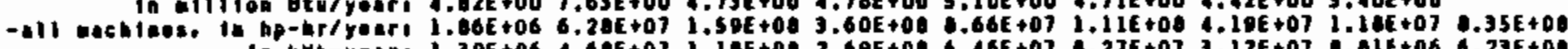

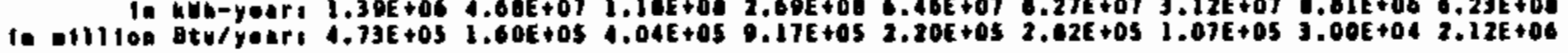

2.3. DALLIMG MACKINE GROUP

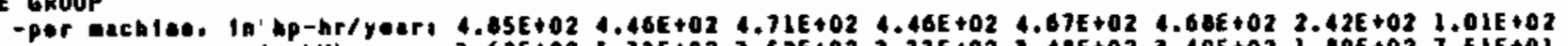

Ia hHh-Yeart $3.62 E+02 \quad 5.33 E+02 \quad 3.52 E+02 \quad 3.33 E+02 \quad 3.48 E+02 \quad 3.40 E+02 \quad 1.80 E+02 \quad 7.51 E+01$

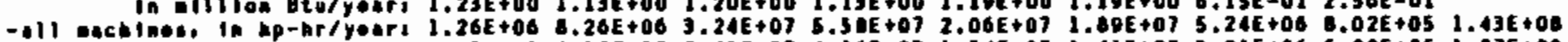

to kWh-yeer, $9.43 E+056.16 E+08$ 2.41E+07 $4.16 E+071.54 E+071.41 E+073.916+065.98 E+051.07 E+08$

in 111 E

2.4. MILLIMQ MACHIME GROUP

-per aschlge, to hp-hr/yoare $7.72 E+02 \quad 4.73 E+02 \quad 7.60 E+027.35 E+02 \quad 1.30 E+027.66 E+02 \quad 5.30 E+02 \quad 4.59 E+02$

in kWh-yoari $5.76 E+02 \quad 3.53 E+02 \quad 5.73 E+02 \quad 5.40 E+02 \quad 5.44 E+025.11 E+023.95 E+023.42 E+02$

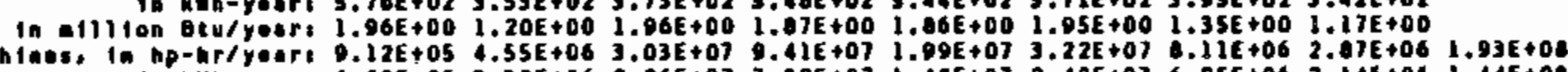

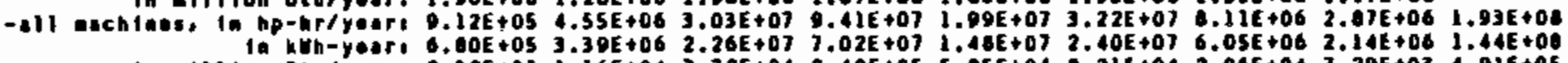

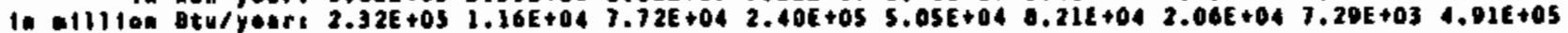

2.5. QROACHING MACHINE GROUP

-per aAchial, in hp-hr/yeard $1.54 E+03 \quad 7.09 E+02 \quad 1.56 E+03 \quad 1.54 E+03 \quad 1.46 E+03 \quad 1.56 E+031.63 E+031.90 E+03$

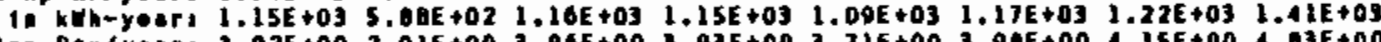

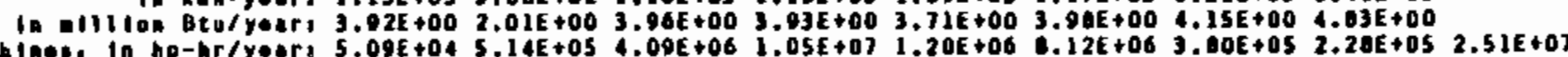

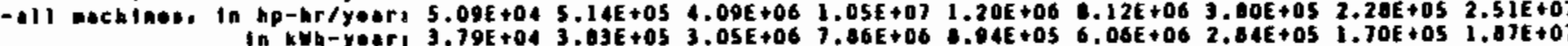

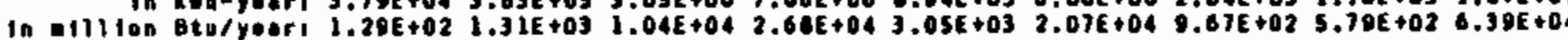

2.6. SAMIMG MACHIME GROUP

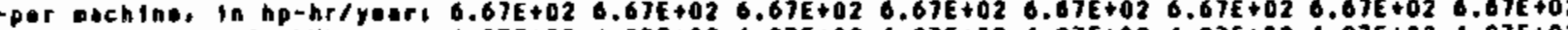

1n kth-yeer: $4.97 E+02 \quad 4.97 E+02 \quad 4.07 E+02 \quad 4.97 E+02 \quad 4.07 E+02 \quad 1.07 E+02 \quad 4.97 E+02 \quad 4.07 E+02$

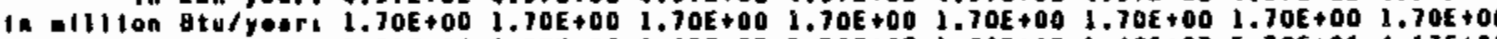

-11 eachines. in bp-hr/yoari 1.51E+06 $6.97 E+06 \quad 2.67 E+07 \quad 3.79 E+07 \quad 1.26 E+071.42 E+075.72 E+06 \quad 4.67 E+06 \quad 1.19 E+08$

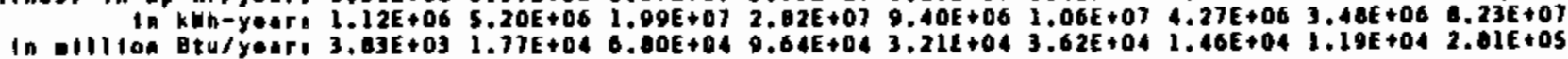

3. TOTAL FRICTJOMAL SINK

3.1. ALL MACHINE GROUPS 
IABLE 5.1. (contd)

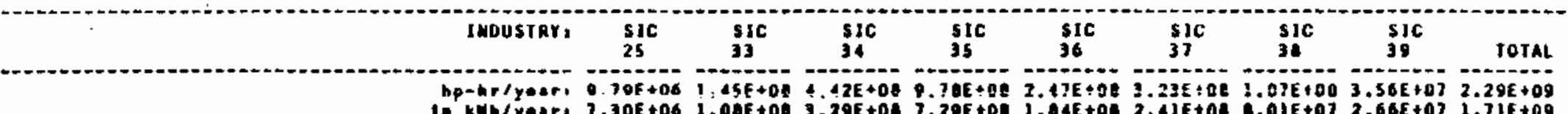

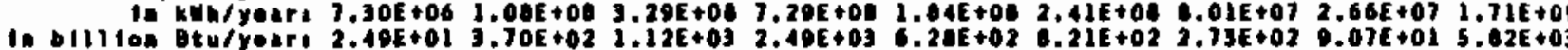

3.2. TURmI Me Machlae GROUP

-por eachlan, In hp-hr/yeari $3.31 E+035.25 E+03 \quad 3.26 E+03 \quad 3.29 E+03 \quad 3.51 E+03 \quad 3.24 E+03 \quad 3.04 E+032.34 E+03$ In $h$ Wh-your $2,47 E+033.01 E+03 \quad 2.43 E+032.45 E+03 \quad 2.62 E+03 \quad 2.42 E+03 \quad 2.27 E+03 \quad 1.74 E+03$

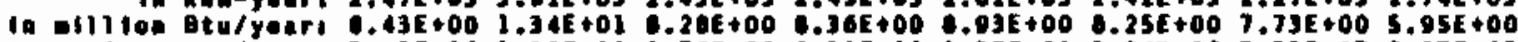

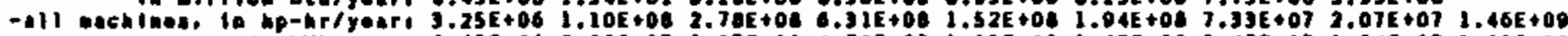

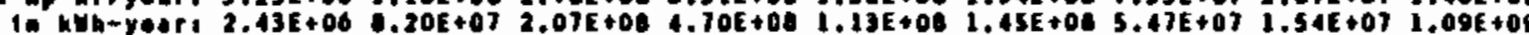

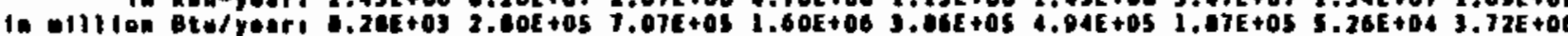

3.3. ORILLIUG MACHIME GROUP

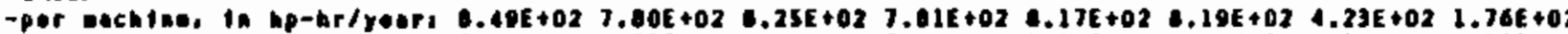

10 kWh-yoer1 $6.33 E+025.02 E+026.15 E+025.02 E+02$ 6.20E+02 $0.11 E+02$ 3.15E+02 $1.31 E+02$

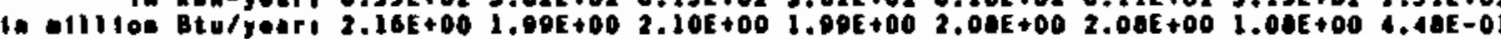

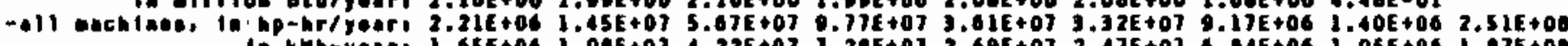

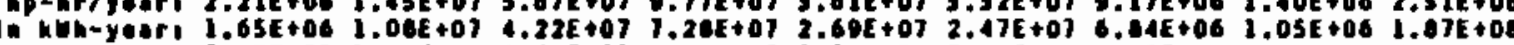

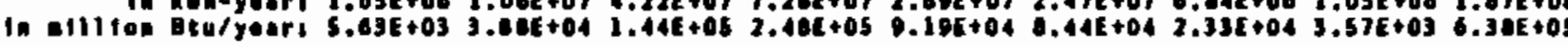

3.4. milline machime group

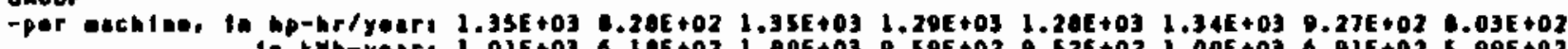

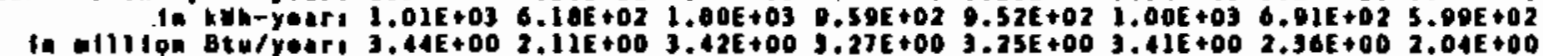

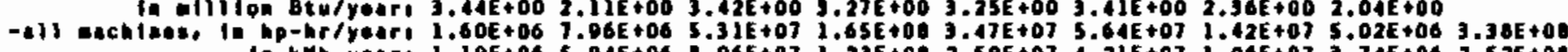

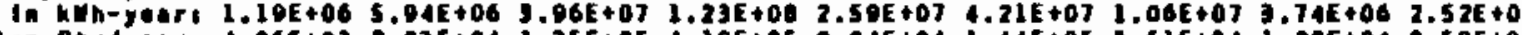

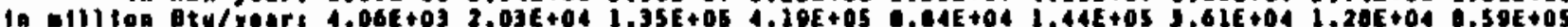

3.5. OROACHIMG MACHIHE GROUP

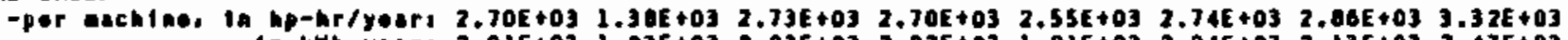

1. WWh-yoer, $2.01 E+03$ 1.03E+03 $2.03 E+032.02 E+03$ 1.01E+03 2.04E+03 2.13E+03 $2.47 E+03$

in a11110a Btu/year, 6.86E+00 3.51E+00 $5.93 E+006.06 E+008.50 E+006.96 E+007.27 E+00 \quad 3.44 E+00$

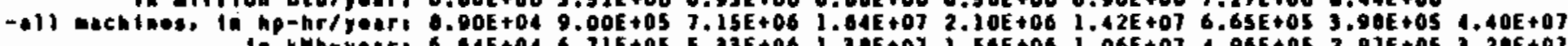

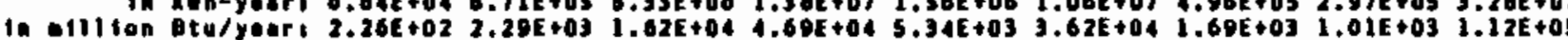

3.6. SALIHG MACHIME GROUP

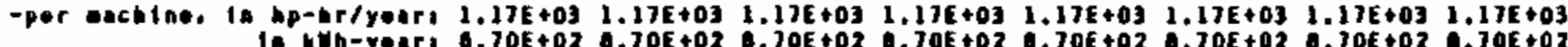

IA WH-yoer, $6.70 E+02 \quad 0.70 E+02 \quad 0.70 E+02 \quad 0.70 E+02 \quad 0.70 E+02 \quad 0.70 E+02 \quad 0.70 E+02 \quad 0.70 E+02$

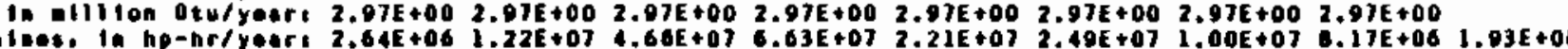

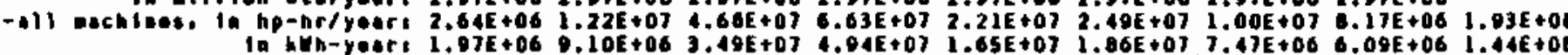

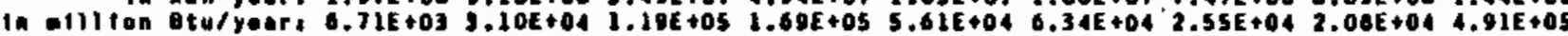

4. FRICTIOMAL SIMK REOUCTION FRON USING SUAFACE MOOJFIED TOOLS

4.1. ALL MACHIME GROUPS

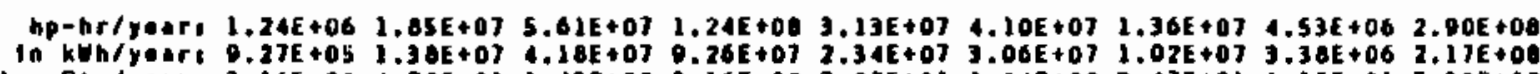

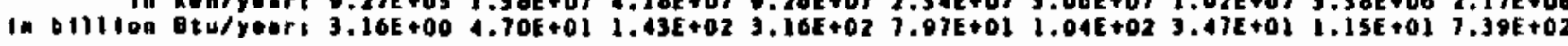


TABLE 5.1. (contd)

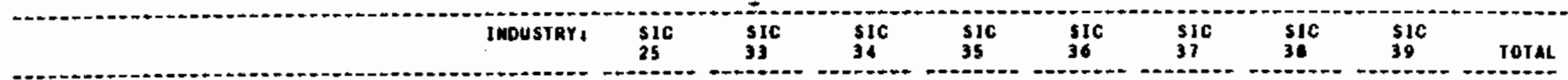

4.2. TURNIMG MACHIME GROUP

-per eachlae, Ia hp-he/yeari 4.21E+02 6.67E+02 4.13E+02 4.17E+02 4.45E+02 4.12E+02 3.66E+02 2,97E+02

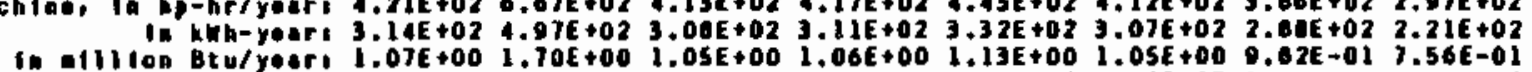

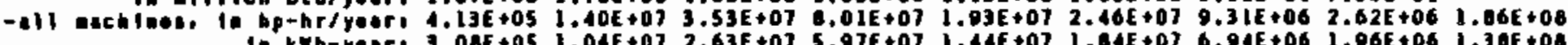

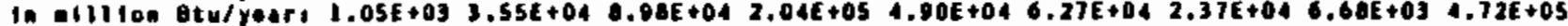

1.3. ORILLING MACHINE GROUP

-per wachlae, In hp-hr/yohrl 1.00E+02 9.01E+01 l.05E+02 9.01E+01 1.04E+02 1.04E+02 5,3JE+01 2.24E+01

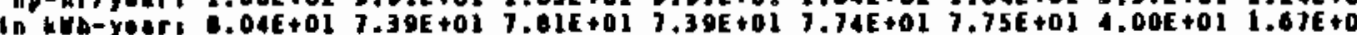
in $=111$ lon Btu/year: 2.74t-01 2.52E-01 2.67E-01 2.52E-01 2.64E-01 2.65E-01 1.37E-01 5.69E-02

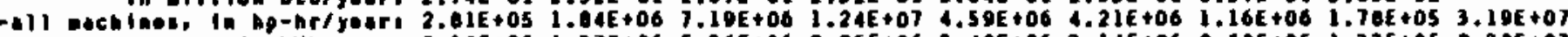

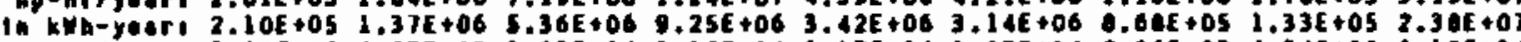

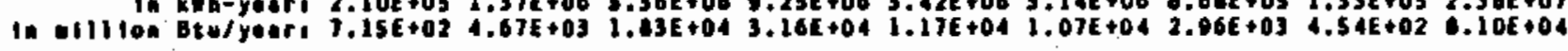
4.4. MILLIMG MACHINE GROUP

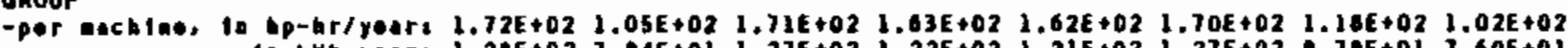
1n kWh-yeari $1.28 E+02$ 7.04E+01 $1.27 E+02$ 1.22E+02 $1.21 E+02 \quad 1.27 E+02 \quad 0.70 E+01 \quad 3.60 E+01$ 10.11110n otulyeari 4.36E-01 2.60E-01 4.35E-01 4.15E-01 4.13E-01 4.33E-01 2.09E-01 2.59E-01

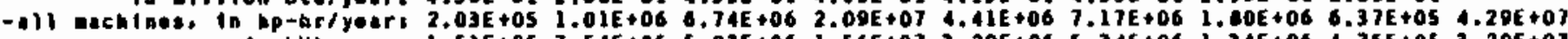

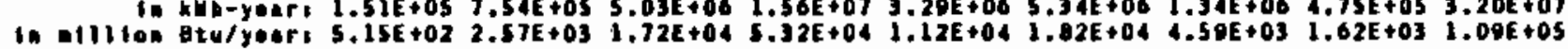

4.5. GROACHIMG MACHINE GROUP

-per eschino, in hp-hr/year, 3.43E+02 $1.75 E+02 \quad 3.46 E+02 \quad 3.43 E+02 \quad 3.24 E+02 \quad 3.47 E+02 \quad 3.63 E+02 \quad 4.21 E+02$ In $k H h-y=0 r 12.55 E+02 \quad 1.31 E+02 \quad 2.58 E+02 \quad 2.56 E+02 \quad 2.42 E+02 \quad 2.50 E+02 \quad 2.70 E+02 \quad 3.14 E+02$

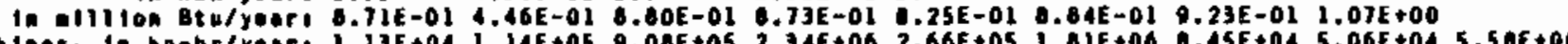

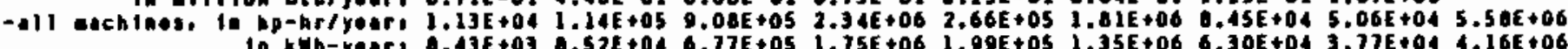

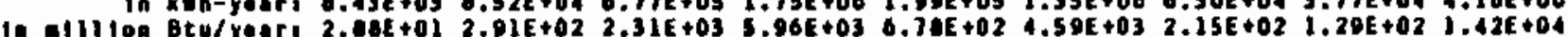

4.6. SAMIMG MACHIME GROUP

-per Eachlan, In hp-hr/yeort $1.48 E+02 \quad 1.48 E+02 \quad 1.48 E+02 \quad 1.48 E+02 \quad 1.40 E+02 \quad 1.40 E+02 \quad 1.40 E+02 \quad 1.48 E+02$

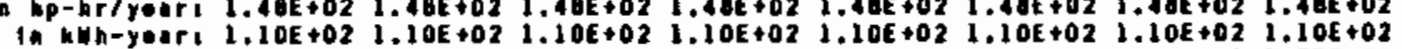

in DIJ

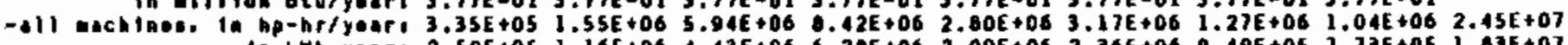
IA $k$ Wh-year, 2.50E +05 $1.16 E+064.43 E+06 \quad 6.20 E+062.09 E+06 \quad 2.36 E+06 \quad 0.49 E+053.73 E+051.03 E+07$

In Elllion Btw/yoAr, $0.52 E+02 \quad 3.94 E+03 \quad 1.51 E+042.14 E+043.13 E+03 \quad 0.06 E+03 \quad 3+24 E+03 \quad 2.64 E+03 \quad 6.24 E+04$ 


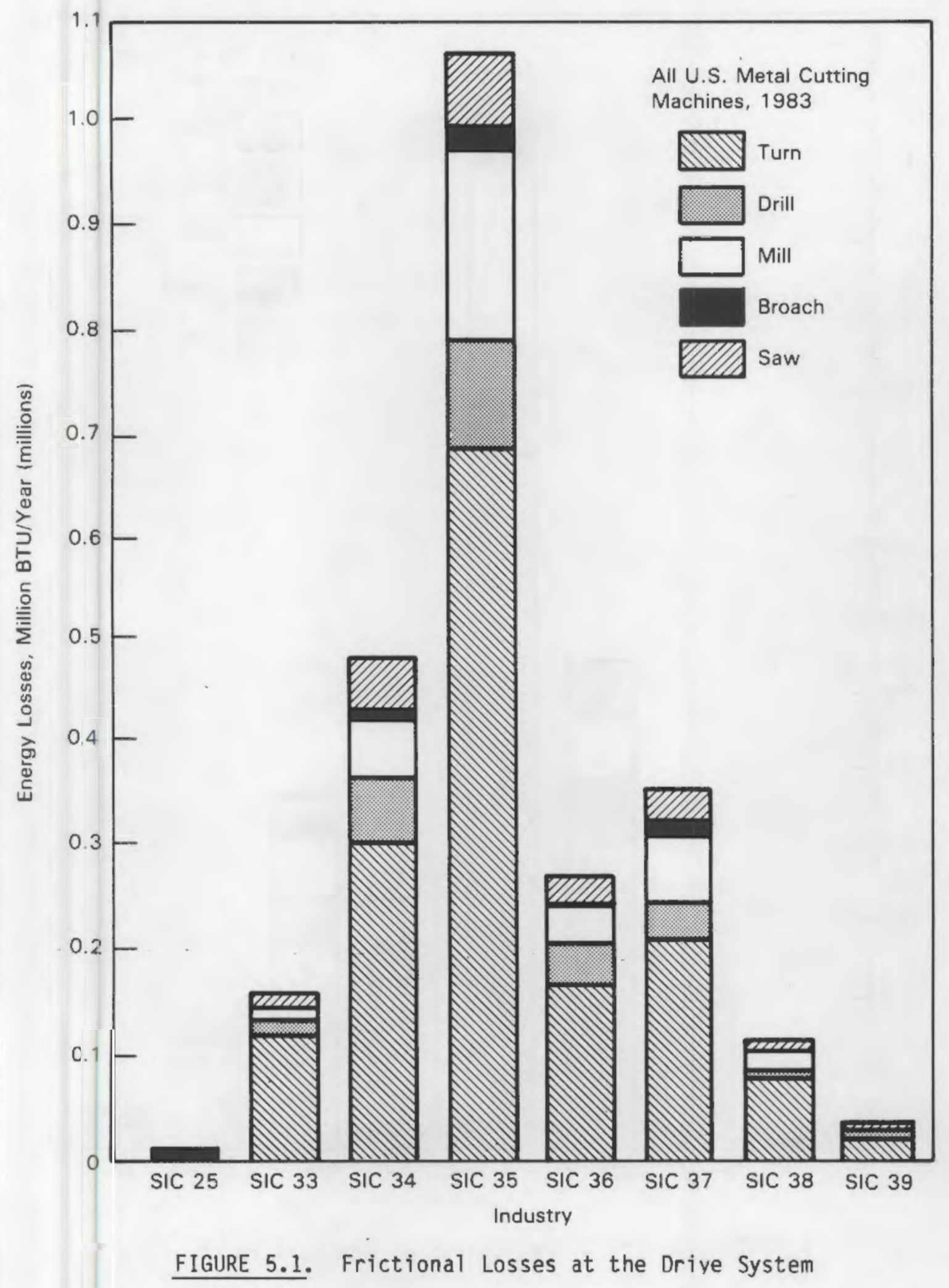

5.7 


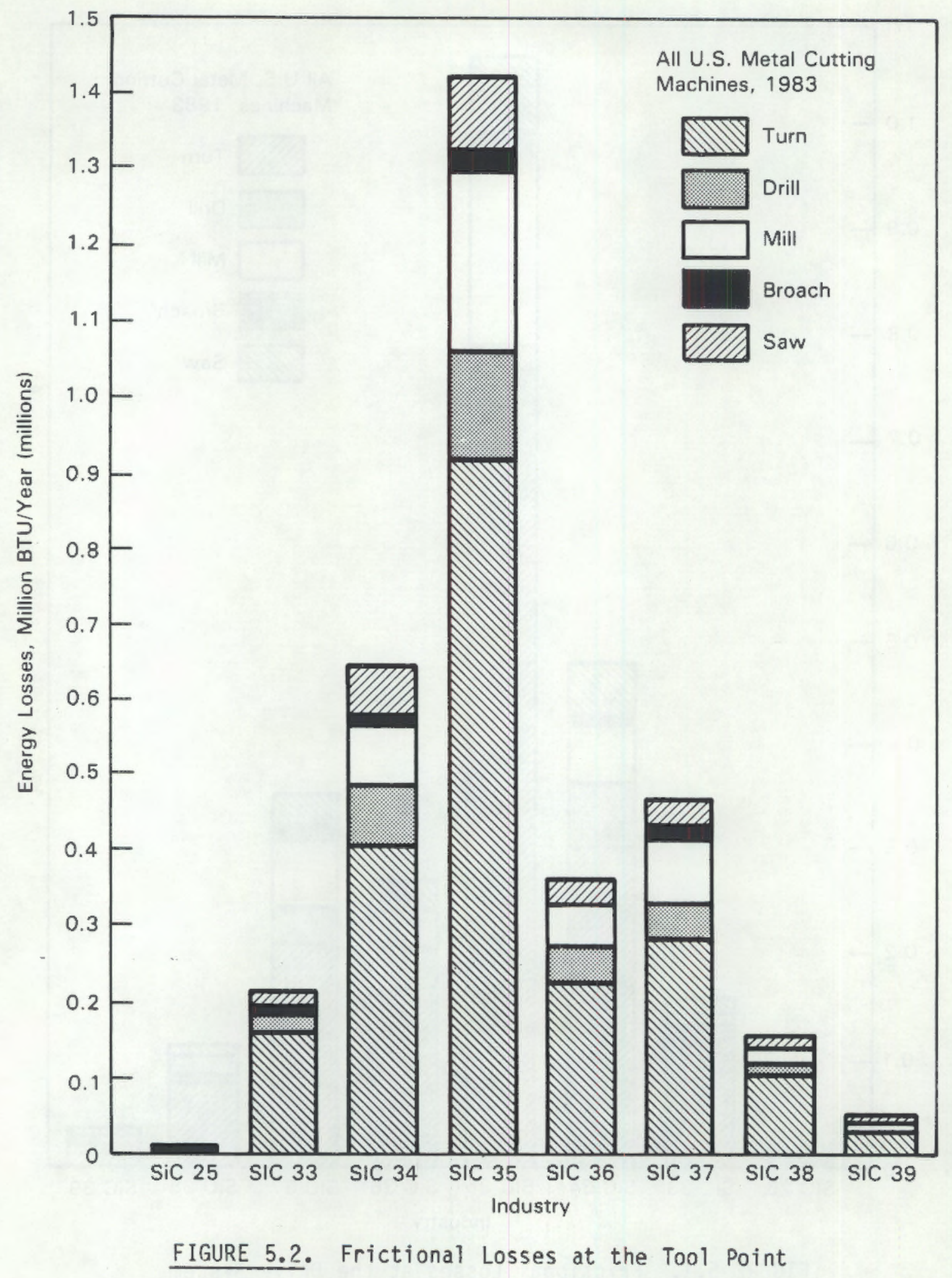


perspective, Industry Group SIC 35, Machinery Except Electrical, would account for 316 billion Btu/year of the total potential energy savings. Figure 5.3 shows these savings by machine group and industry.

\subsubsection{Energy Savings Achievable from Wear Reduction with Surface Modification Technologies}

The use of surface modified tools has been shown to increase tool life anywhere from 200 to 1,100 percent. Assuming conservatively that a 600 percent increase in tool life could be achieved, the energy saved annually would be 1,936 billion Btu/year.

\subsubsection{Metalcutting Summary}

This study estimates that of the 8,133 billion Btu lost per year in the metalcutting tribological sink, approximately 2,675 billion Btu/year, or 33 percent, might be eliminated through the use of surface modified tools.

\subsection{EFFECTS OF SURFACE MONIFICATION TECHNOLOGIES IN METALFORMING}

Table 5.2 shows calculations for the frictional tribological sink and the energy savings achievable with the use of surface modified tools in metalforming. These calculations were made using an average coefficient of friction of 0.10 , a 25 percent decrease in the coefficient of friction when surface modified tools are used, and an efficiency ratio of 0.3 for punching machines. Highlights of the results of these calculations are described below.

\subsubsection{The Frictional Sink in Metalforming}

As in metalcutting machines, frictional losses in metalforming machines occur at the drive system and the tool point. This study estimates that for a regular work year of 2,000 hours, frictional losses at the drive system of metalforming machines are about 10,400 billion Btu/year; frictional losses at the tool point are 4,000 billion Btu/year. The origins of frictional losses by machine type and industry are shown in Figure 5.4 for 10 sses at the drive system and in Figure 5.5 for losses at the tool point. 


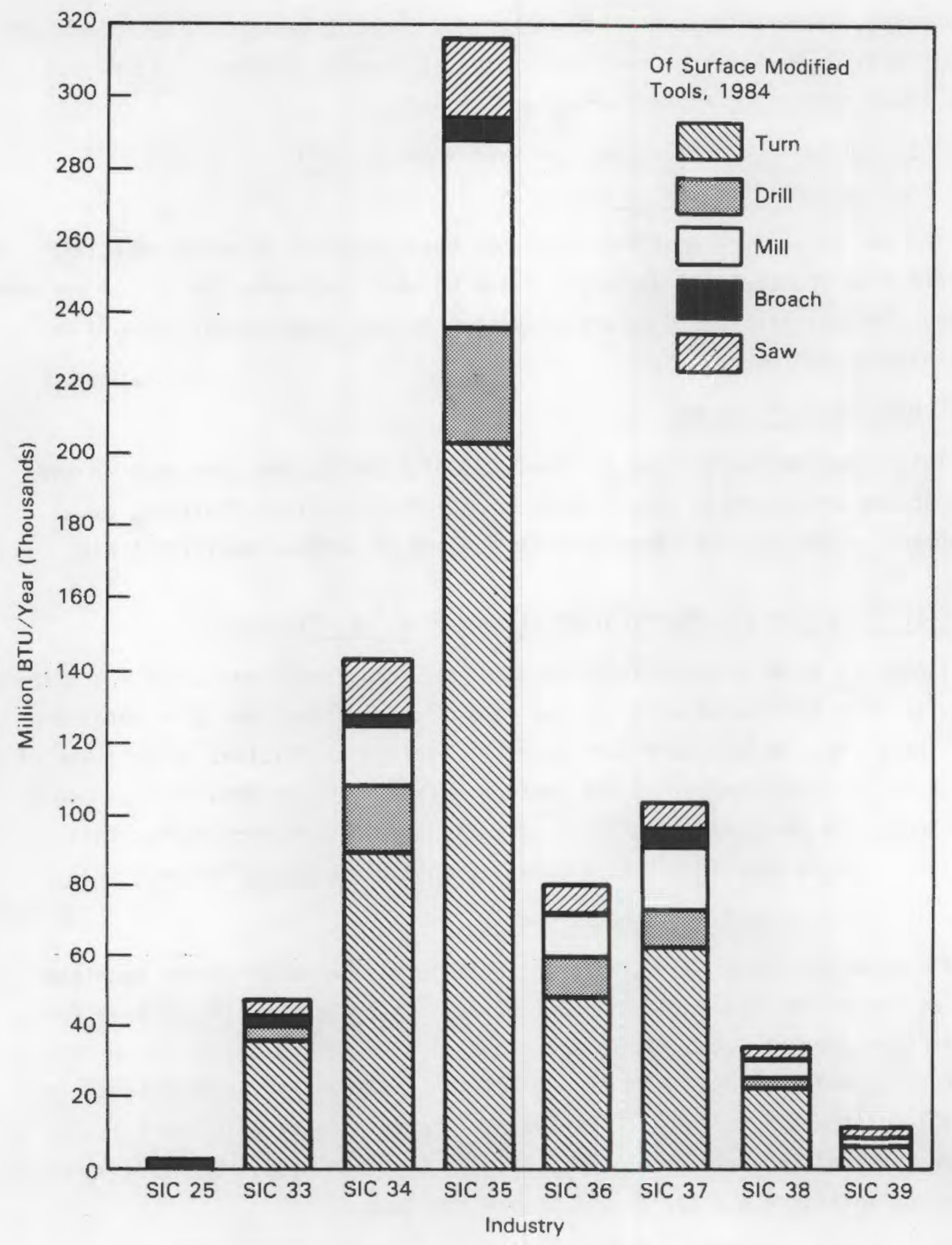

FIGURE 5.3. Metalcutting Energy Savings Potential 
TABLE 5.2. Metalforming Energy Savings Estimation Model, Frictional Sink

Consumption: up $=0.3 ; \mathrm{mu}=0.10 ; \mathrm{u} 2 / \mathrm{ul}=0.75$

INOUSTRY SIC 25 SIC 33

SIC 34 SIC 35 SIC 36 SIC 37 SIC 36 SIC 39 TOTAL
A) MODEL IMPUTS

PUNCHING MACHINES (number of nachinos),

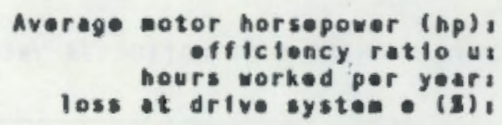

loss at drive systeo e (s),

PRESSES ANO FORGES (nuaber of nachinos):

Average notor hor sepover $(h p)$,

everege coeffictent of frictioni

hours

loss ot drive systoe (s),

800
10
0.3
2000
0.2
9040
26.95
0.10
0.1
2000
0.2

1265
10
0.3
2000
0.2

13671

16380

$13671 \quad 10061$

4772

3215

1765

1504

37053

114356

10
0.3
2000
0.2

10
0.3
2000
0.2

10
0.3
2000
0.2

10
0.3
2000
0.2

10
0.3
2000

$44.55 \quad 34.40$

46479

45114

32316

11570

$34.21 \quad 30.23$

$\begin{array}{rr}0.10 & 0.10 \\ 0.1 & 0.1 \\ 2000 & 2000\end{array}$

0.10

2000

0.10

36.76

0.10

2000

28.91

0.10

2000

2000
0.2

0.3
2000
0.2

EFFECTS OF SURFACE MODIFICATION TECHNOL OGIES,

ratto of new/old coefficient of frictioni

0.75

0.75

0.75

0.75

0.75

0.75

0.75

0.75

1. FRICTIOMAL SIMK AT MOTOR DRIVE SYSTEM

1.1 All achines

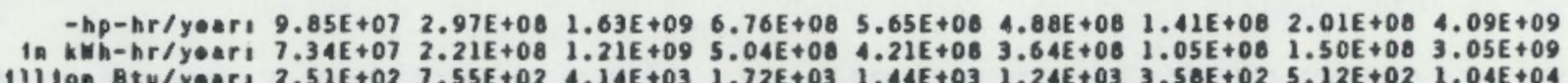
In billion Btulyeeri $2.52 E+02 \quad 7.55 E+02 \quad 4.14 E+03 \quad 1.72 E+03 \quad 1.44 E+03 \quad 1.24 E+03 \quad 3.58 E+025.12 E+021.04 E+04$

1.2 Punching machines

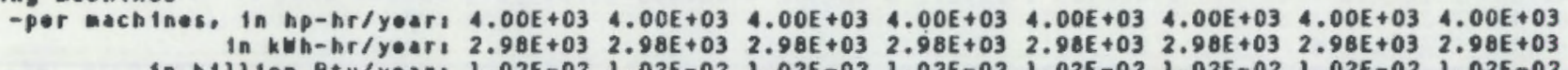

In b1lilion Btulyear, 1.02E-02 $1.02 E-02$ 1.02E-02 $1.02 E-02$ 1.02E-02 1.02E-02 1.02E-02 $1.02 E-02$

- 11 machines, in hp-hr/year: $3.20 E+06 \quad 5.06 E+06 \quad 5.47 E+07 \quad 4.02 E+07 \quad 1.91 E+07 \quad 1.29 E+07 \quad 7.06 E+06 \quad 6.02 E+06 \quad 1.48 E+08$

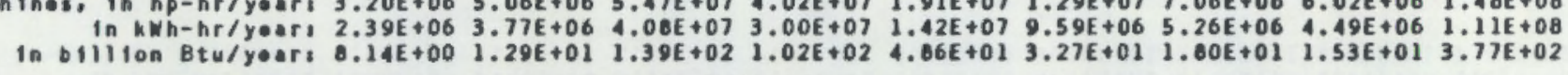

1.3 Pressos and forges

-per aechines, in hp-hr/yeart 1.05E+04 1.78E+04 $1.38 E+041.37 E+04 \quad 1.21 E+041.47 E+041.16 E+041.37 E+04$ In $k$ Wh-hr/yoari $7.86 E+03 \quad 1.33 E+04 \quad 1.03 E+04 \quad 1.02 E+04 \quad 9.02 E+03 \quad 1.10 E+04 \quad 0.62 E+03 \quad 1.02 E+04$

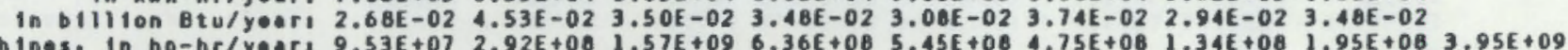

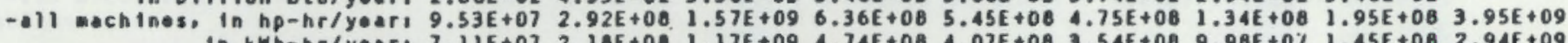

in Dillion $\theta t u / y+a r$, $2.42 E+02 \quad 7.43 E+024.00 E+03 \quad 1.62 E+03 \quad 1.39 E+03 \quad 1.21 E+03 \quad 3.40 E+02 \quad 4.96 E+021.00 E+04$

2. FRICTIONAL SINK AT TOOL-WORK PIECE INTERFACE

2.1 All machines 
TABLE 5.2. (contd)

INDUSTRY SIC 25 SIC 33 SIC 34 SIC 35 SIC 36 SIC 37 SIC 38 SIC 39 TOTAL

hp-hr/yoars $3.76 \mathrm{E}+07 \quad 1.11 \mathrm{E}+0 \mathrm{0B} \quad 6.23 \mathrm{E}+06 \quad 2.68 \mathrm{EE}+00 \quad 2.16 \mathrm{E}+08 \quad 1.05 \mathrm{E}+08 \quad 5.52 \mathrm{E}+07 \quad 7.65 \mathrm{E}+07 \quad 1.57 \mathrm{E}+09$

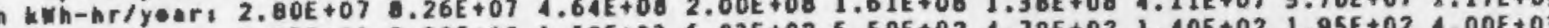
in billiton Btulyeart $9.57 E+012.02 E+02 \quad 1.58 E+03 \quad 6.83 E+025.5 C$

2.2 Punching wachines

-per aechine, In hphr/yeer, $3.69 E+03 \quad 3.69 E+03 \quad 3.69 E+03 \quad 3.69 E+03 \quad 3.69 E+03 \quad 3.69 E+03 \quad 3.69 E+03 \quad 3.69 E+03$

In kWh-hr/year: $2.75 E+03 \quad 2.75 E+03 \quad 2.75 E+03 \quad 2.75 E+03 \quad 2.75 E+03 \quad 2.75 E+03 \quad 2.75 E+03 \quad 2.75 E+03$

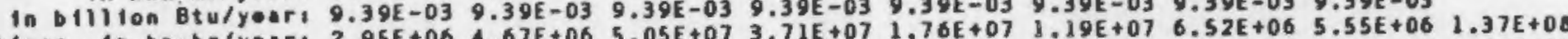

-11 machinos, in hp-hrfyeori 2.95E+06 $4.67 E+06$.05E

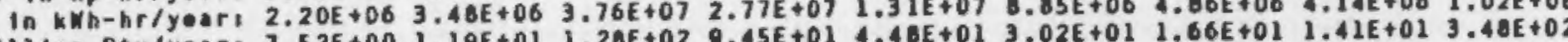

in billion Btulyears $7.52 E+001.19 E+01 \quad 1.28 E+02 \quad 0.45 E+01$ 4.48E+01 $3.02 E+01 \quad 1.66 E+01 \quad 1.41 E+013.40 E+02$

2.3 Prossos and forges

- per achine, in hp-hr/yeari $3.03 E+03 \quad 6.48 E+03 \quad 5.00 E+03 \quad 4.98 E+03 \quad 4.40 E+03 \quad 5.35 E+03 \quad 4.20 E+03 \quad 4.97 E+03$ in whi-hrlyoari $2.86 E+034.83 E+03 \quad 3.73 E+03 \quad 3.71 E+03 \quad 3.28 E+03 \quad 3.99 E+03 \quad 3.14 E+03 \quad 3.70 E+03$

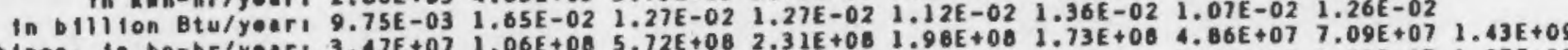

- 11 mechines. In hp-hr/yoars $3.47 E+07$ T.06E in $b 11$

3. TOTAL FRICTIOMAL SIMK

3.1 A11 eachines

hp-hr/yearl $1.36 E+08 \quad 4.08 E+00 \quad 2.25 E+09 \quad 9.45 E+08 \quad 7.01 E+08 \quad 6.73 E+08 \quad 1.96 E+06 \quad 2.78 E+08 \quad 5.67 E+09$ hp-hr/ycarl $1.30 E+08$.

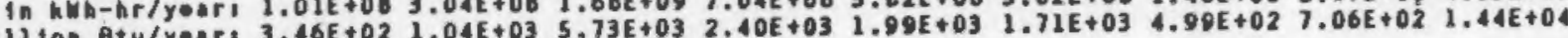

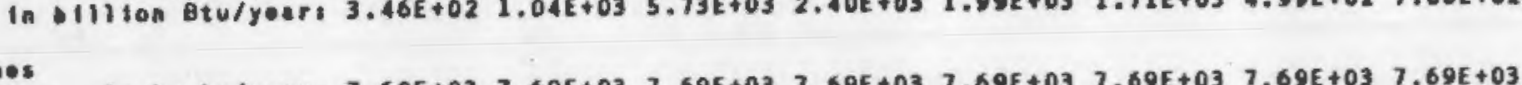

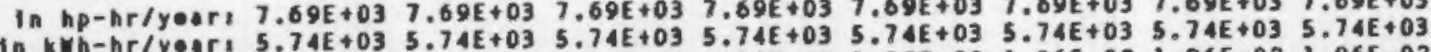

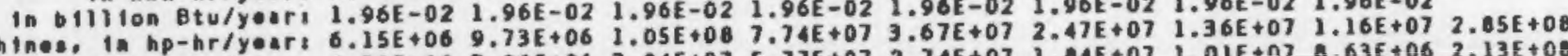

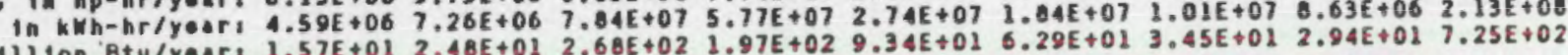

in bilition Btulyear: $1.57 E+01 \quad 2.48 E+01 \quad 2.68 E+02 \quad 1.97 E+02 \quad 9.34 E+02 \quad 6.29 E+013.45 E+012.94 E+02$ (

3.3 Prosses and forges

-per achine, In hp-hr/year: 1.44E+04 2.43E+04 $1.80 E+041.07 E+041.65 E+042.01 E+041.58 E+041.06 E+04$

In $k W h-h r l y 0 a r, 1.07 E+041.01 E+041.40 E+04 \quad 1.39 E+041.23 E+04 \quad 1.50 E+04 \quad 1.18 E+04 \quad 1.39 E+04$

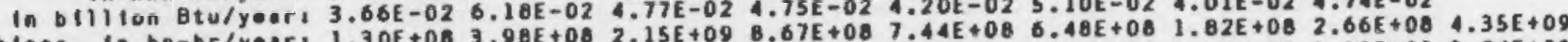

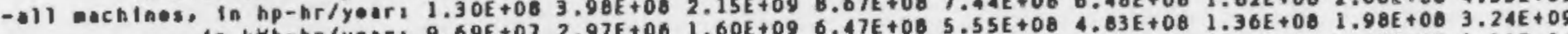

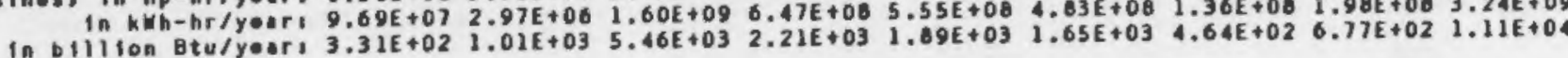

4. FRICTIONAL SIMK REDUCIION FROM USING SURFACE MOOIFIEO TOOLS

4.1 All eachines

Mp-hr/year: $1.04 E+07 \quad 3.09 E+07 \quad 1.72 E+08 \quad 7.29 E+07 \quad 5.97 E+07 \quad 5.13 E+07 \quad 1.51 E+07 \quad 2.12 E+07 \quad 4.33 E+08$

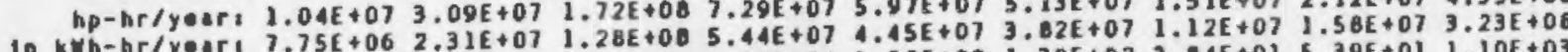
In b111 $00 \mathrm{Ot}$ 
TABLE 5.2. (contd)

\begin{tabular}{|c|c|c|c|c|c|c|c|c|c|c|c|}
\hline & & INDUSTAY & sic 25 & SIC 33 & SIC 34 & 51035 & $51 C 36$ & $51 C 37$ & SIC 38 & sic 39 & TOTAL \\
\hline 1,2 & $\begin{array}{c}\text { unching } \\
-p e \\
-a l\end{array}$ & 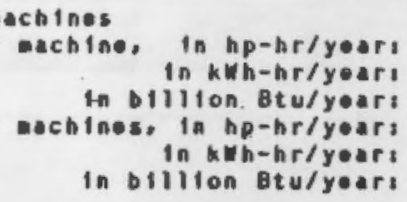 & $\begin{array}{l}7.54 E+02 \\
5.62 E+02 \\
1.92 E-03 \\
6.03 E+05 \\
4.50 E+05 \\
1.53 E+00\end{array}$ & $\begin{array}{l}7.54 \mathrm{E}+02 \\
5.62 \mathrm{E}+02 \\
1.92 \mathrm{E}-03 \\
9.53 \mathrm{E}+05 \\
7.11 \mathrm{E}+05 \\
2.43 \mathrm{E}+00\end{array}$ & $\begin{array}{l}7.54 \mathrm{E}+02 \\
5.62 \mathrm{E}+02 \\
1.92 \mathrm{E}-03 \\
1.03 \mathrm{E}+07 \\
7.68 \mathrm{E}+06 \\
2.62 \mathrm{E}+01\end{array}$ & $\begin{array}{l}7.54 \mathrm{E}+02 \\
5.62 \mathrm{E}+02 \\
1.92 \mathrm{E}-03 \\
7.58 \mathrm{E}+06 \\
5.65 \mathrm{E}+06 \\
1.93 \mathrm{E}+01\end{array}$ & $\begin{array}{l}7.54 E+02 \\
5.62 E+02 \\
1.92 E-03 \\
3.60 E+06 \\
2.60 E+06 \\
9.15 E+00\end{array}$ & $\begin{array}{l}7.54 E+02 \\
5.62 E+02 \\
1.92 E-03 \\
2.42 E+06 \\
1.01 E+06 \\
6.16 E+00\end{array}$ & $\begin{array}{l}7.54 E+02 \\
5.62 E+02 \\
1.92 E-03 \\
1.33 E+06 \\
9.92 E+05 \\
3.38 E+00\end{array}$ & $\begin{array}{l}7.54 E+02 \\
5.62 E+02 \\
1.92 E-03 \\
1.13 E+06 \\
6.45 E+05 \\
2.00 E+00\end{array}$ & $\begin{array}{l}2.79 E+07 \\
2.08 E+07 \\
7.10 E+01\end{array}$ \\
\hline & $\begin{array}{r}\text { resses an } \\
-\$ 11\end{array}$ & 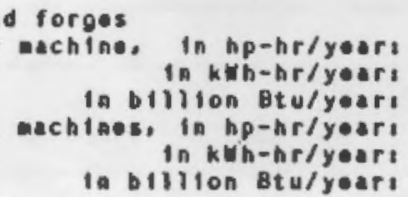 & $\begin{array}{l}1.08 E+03 \\
8.08 E+02 \\
2.76 E-03 \\
9.79 E+06 \\
7.30 E+06 \\
2.49 E+01\end{array}$ & $\begin{array}{l}1.83 E+03 \\
1.37 E+03 \\
4.66 E-03 \\
3.00 E+07 \\
2.24 E+07 \\
7.63 E+01\end{array}$ & $\begin{array}{l}1.41 E+03 \\
1.05 E+03 \\
3.60 E-03 \\
1.62 E+00 \\
1.21 E+00 \\
4.11 E+02\end{array}$ & $\begin{array}{l}1.41 E+03 \\
1.05 E+03 \\
3.58 E-03 \\
6.54 E+07 \\
4.87 E+07 \\
1.66 E+02\end{array}$ & $\begin{array}{l}1.24 E+03 \\
9.27 E+02 \\
3.16 E-03 \\
5.61 E+07 \\
4.16 E+07 \\
1.43 E+02\end{array}$ & $\begin{array}{l}1.51 E+03 \\
1.13 E+03 \\
3.84 E-03 \\
1.08 E+07 \\
3.64 E+07 \\
1.24 E+02\end{array}$ & $\begin{array}{l}1.19 E+03 \\
8.86 E+02 \\
3.02 E-03 \\
1.37 E+07 \\
1.03 E+07 \\
3.50 E+01\end{array}$ & $\begin{array}{l}1.40 E+03 \\
1.05 E+03 \\
3.57 E-03 \\
2.00 E+07 \\
1.49 E+07 \\
5.10 E+01\end{array}$ & $\begin{array}{l}4.06 E+08 \\
3.02 E+08 \\
1.03 E+03\end{array}$ \\
\hline
\end{tabular}




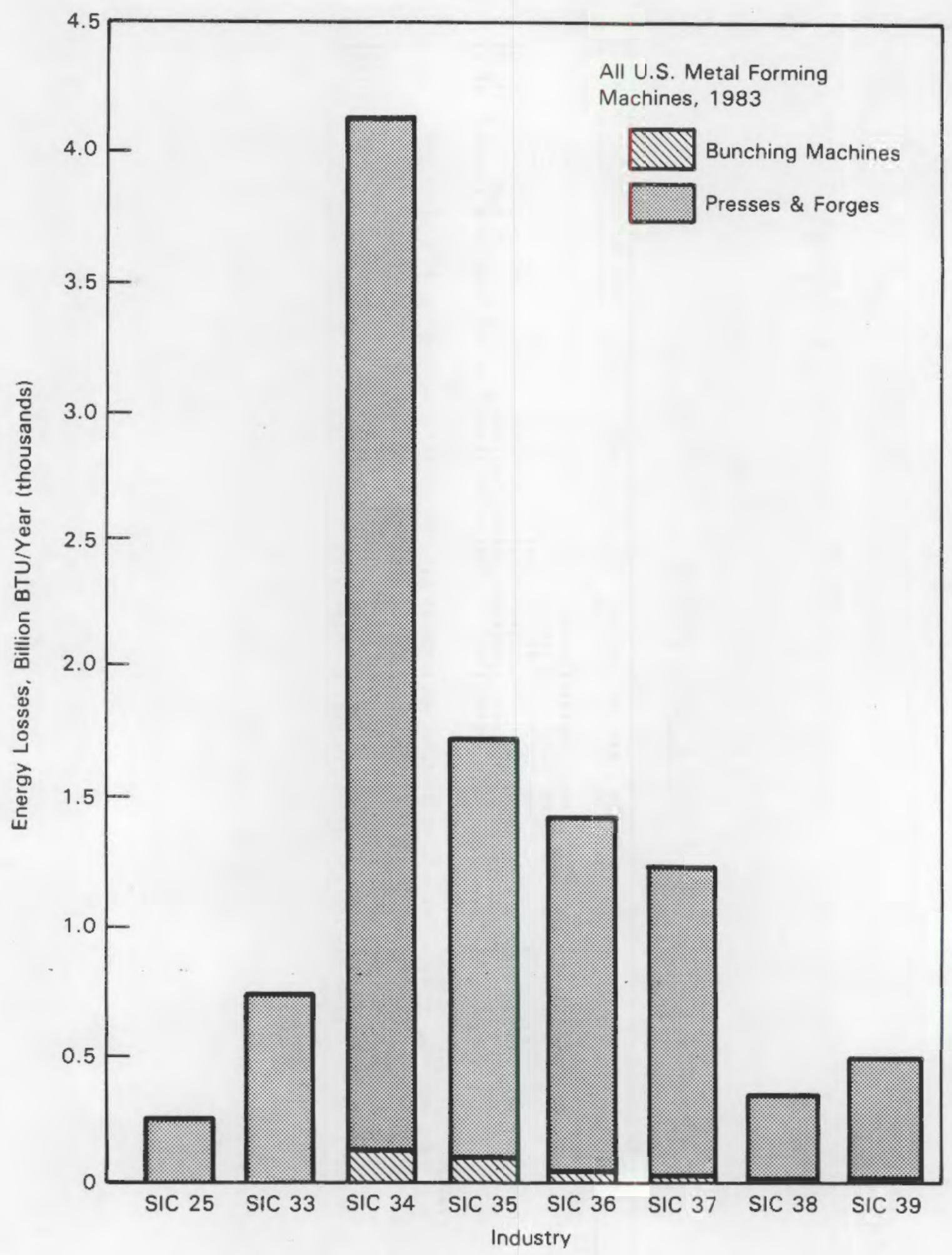

FIGURE 5.4. Frictional Losses at the Drive System 


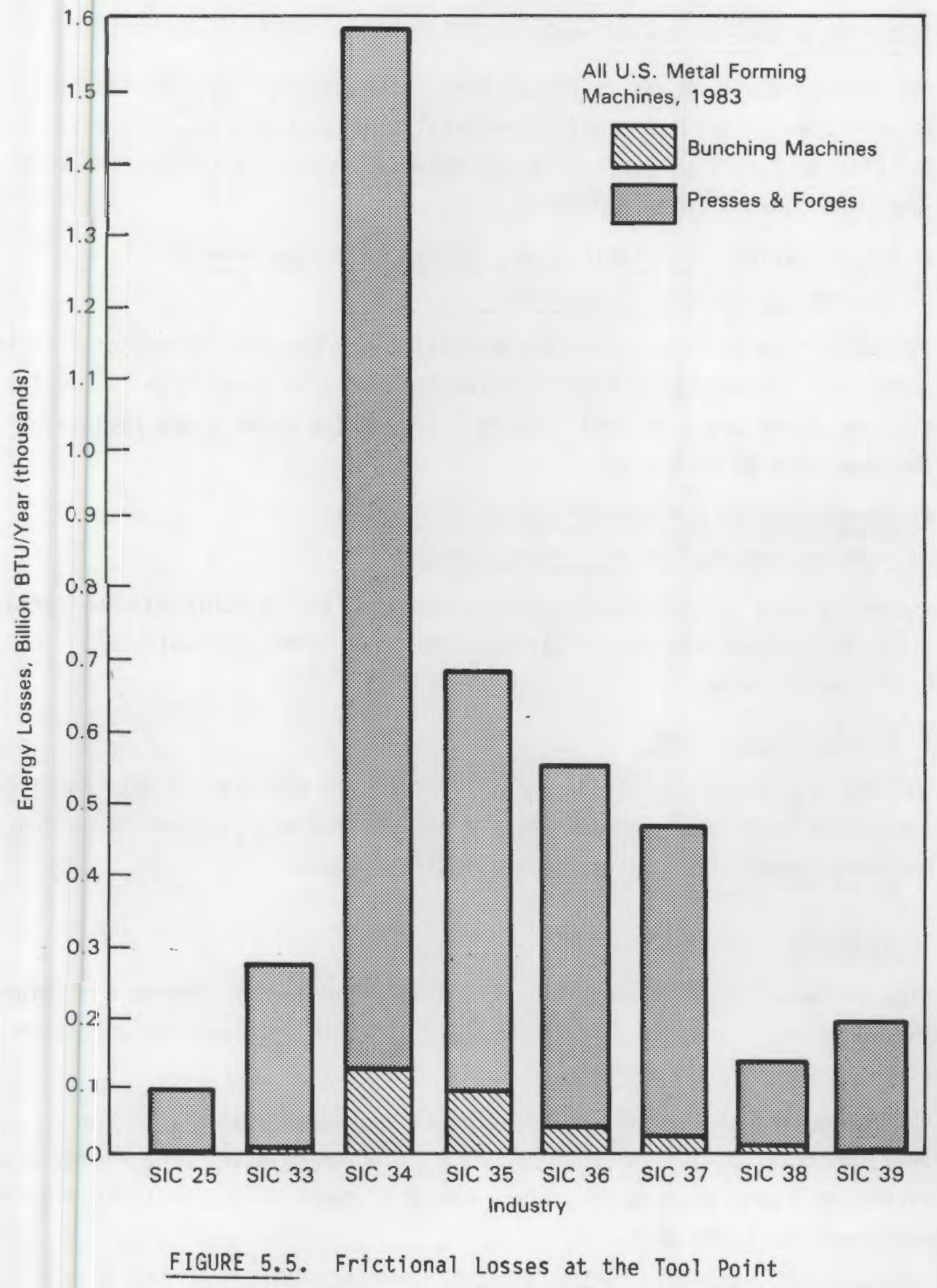




\subsubsection{The Wear Sink in Metalforming}

In Section 4.4.4 it was estimated that approximately 272,610 tons of steels were used in 1983 to manufacture metalforming dies, jigs, and fixtures. With 19.2 million Btu/ton as the embodied energy of steels, the wear sink would be 5,370 billion Btu/year.

\subsubsection{Energy Savings Achievable from Friction Reduction with} Surface Modification Technologies

Assuming that surface modified tools can lower the coefficient of friction by 25 percent, approximately 1,100 billion Btu would be saved from the fullscale use of these tools in metalforming. Figure 5.6 shows these savings by machine group and by industry.

\subsubsection{Energy Savings Achievable from Wear Reduction with Surface Modification Technologies}

Assuming that a 300 percent increase in tool life is achieved when surface modification is used, the energy savings from wear reduction would be 2,666 billion Btu/year.

\subsubsection{Metalforming Summary}

of the 19,770 billion Btu/year lost to friction and wear in metalforming, this study estimates that approximately 4,680 billion Btu/year, or 24 percent, can be saved through the use of surface modified tools.

\subsection{DISCUSSION}

The estimates for the tribological sink and the energy savings that might be achieved with the use of surface modified tools in metalworking are shown in Table 5.3.

The tribological sink in metalworking is approximately 28 trillion Btu/year, 20 trillion due to friction and 8 trillion to wear. The energy savings achievable with the use of surface modified tools is 7.3 trillion Btu, or 26 percent of the total sink.

Assuming an electricity purchase price of $\$ 12 / \mathrm{milli}$ ion Btu, the dollar costs of tribological losses total $\$ 335 \mathrm{million} /$ year; at the same time, the 


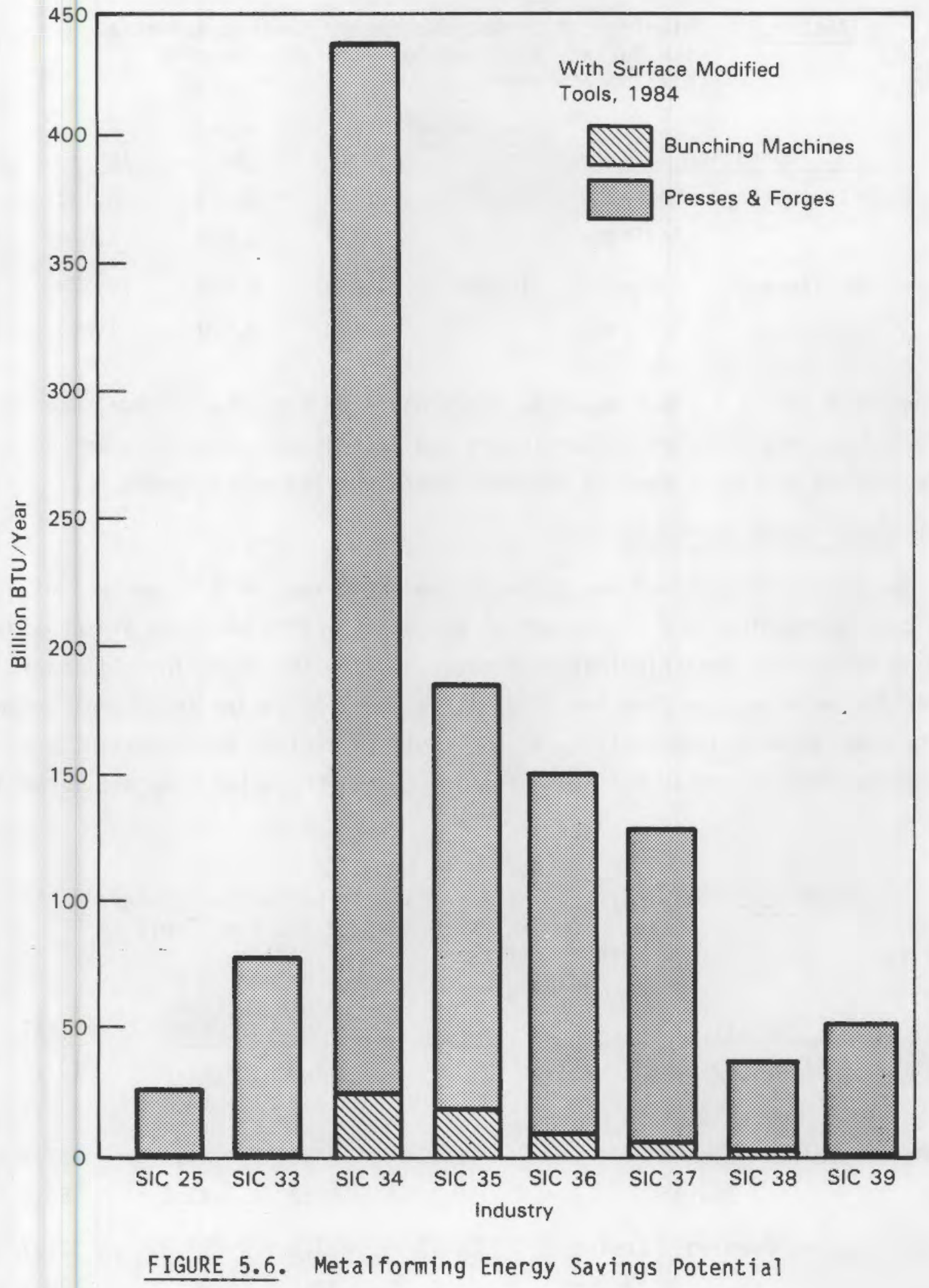


TABLE 5.3. Tribological Losses and Energy Savings Potential with Surface Modified Tools in Metalworking (billion Btu/year)

\begin{tabular}{|c|c|c|c|c|c|}
\hline \multicolumn{2}{|c|}{ Operation } & $\begin{array}{l}\text { Frictional } \\
\text { Drive }\end{array}$ & $\begin{array}{l}\text { Sink } \\
\text { Tool }\end{array}$ & $\begin{array}{l}\text { Wear } \\
\text { Sink }\end{array}$ & Total \\
\hline \multirow[t]{2}{*}{ Metalcutting: } & Losses & 2,490 & 3,320 & 2,323 & 8,133 \\
\hline & Savings & 0 & 739 & 1,936 & 2,675 \\
\hline \multirow[t]{2}{*}{ Metal forming: } & Losses & 10,400 & 4,000 & 5,370 & 19,770 \\
\hline & Savings & 0 & 1,100 & 3,580 & 4,680 \\
\hline
\end{tabular}

savings with use of surface modified tools would be $\$ 88$ million/year (see Table 5.4). Note that the dollar losses and savings are averaged over the whole country without regard to regional variations in energy costs.

\subsubsection{Upper Bound Estimates}

The estimates obtained are probably conservative. Only 72 percent of all metalcutting machines and 74 percent of all metalforming machines are considered in estimating the tribological sinks. Because the basis for eliminating a particular machine type from the study was absence of severe frictional losses at the tool point and amenability of the tools to surface modification, the tool point sink estimates are probably correct and the drive sink estimates are low.

TABLE 5.4. Dollar Values of Tribological Losses and Energy Savings Potential with Surface Modified Tools in Metalworking (million dollars/year)

\begin{tabular}{|c|c|c|c|c|c|}
\hline \multicolumn{2}{|c|}{ Operation } & $\frac{\text { Frict }}{\text { Drive }}$ & $\frac{\text { Sink }}{\text { Tool }}$ & $\begin{array}{l}\text { Wear } \\
\text { Sink }\end{array}$ & Total \\
\hline \multirow[t]{2}{*}{ Metalcutting: } & Losses & 29.9 & 39.8 & 27.8 & 107.5 \\
\hline & Savings & 0 & 8.9 & 23.2 & 32.1 \\
\hline \multirow[t]{2}{*}{ Metalforming: } & Losses & 124.8 & 48.0 & 64.4 & 237.2 \\
\hline & Savings & 0 & 13.2 & 43.0 & 56.2 \\
\hline \multirow[t]{2}{*}{ Cutting and } & rming: Losses & 154.7 & 87.8 & 92.2 & 334.7 \\
\hline & Savings & 0 & 22.1 & 66.2 & 88.3 \\
\hline
\end{tabular}


The same rationale applies to estimated savings. Because DOE is concerned primarily with surface modification of metalworking tools, this study did not consider the effects of surface modified bearings or drive belts; with surface modification, some energy savings would result. The additional savings would probably be a few tenths of a percent of the frictional losses.

For the wear sink computations, $19.2 \mathrm{million}$ Btu/ton of steel were used, reflecting the assumption that metalworking tools are manufactured from scrap steels in electric furnaces. The embodied energy of steels from ores is equal to approximately $37.4 \mathrm{milition}$ Btu/ton. In addition, the wear sink did not include the tools manufactured by large companies that make their own tools.

Assuming then, that the number of machines should be increased by a factor of 1.43 (the study considered only 70 percent of the machines in the United States), that the savings achievable with surface modified machine drive components are approximately 20 percent of the drive sinks, and that the wear sinks should be increased by a factor of 1.95 (the ratio of 37.4 to 19.2 ), then the sinks and savings in Table 5.3 can be adjusted as shown in Table 5.5. In Table 5.j, the upper bound estimates of the tribological losses and energy savings potential with surface modified tools in metalworking are about twice the more conservative estimates.

TABLE 5.5. Upper Bound Estimates of Tribological Losses and Energy Savings Potential with Surface Modified Tools in Metalworking (billion Btu/year)

\begin{tabular}{|c|c|c|c|c|c|c|}
\hline \multicolumn{3}{|c|}{ Operation } & \multicolumn{2}{|c|}{$\frac{\text { Frictional Sink }}{\text { Drive Tool }}$} & $\begin{array}{l}\text { Wear } \\
\text { Sink }\end{array}$ & Total \\
\hline \multirow[t]{2}{*}{ Metilcutting: } & Losses & & 3,560 & 3,320 & 4,529 & 11,409 \\
\hline & Saving & & 712 & 739 & 3,775 & 5,226 \\
\hline \multirow[t]{2}{*}{ Metalforming: } & Losses & & 14,872 & 4,000 & 10,472 & 29,344 \\
\hline & Saving & & 2,974 & 1,100 & 6,910 & 10,984 \\
\hline \multirow[t]{2}{*}{ Cutting } & ing: & Losses & 18,432 & 7,320 & 15,001 & 40,153 \\
\hline & & Savings & 3,686 & 1,839 & 10,658 & 16,210 \\
\hline
\end{tabular}




\subsubsection{Effect of Productivity Increase}

An important effect of surface modification technologies is increased productivity of metalworking operations. But the complex tribological implications of increased productivity are difficult to quantify. In both metalcutting and metalforming, surface modified tools increase productivity because of the higher speed and feed rates and the longer productive cutting times. But increased speed and feed rates are likely to increase the tribological sinks in absolute terms: more horsepower is required at the tool point. Increasing the productive cutting time has the same effect. To analyze the productivity aspects of surface modification technologies requires the develop. ment of a comparable but different model than the one used in this study. 


\section{APPENDIX A}

THE METALWORKING-INTENSIVE INDUSTRIES 
APPENDIX A

THE METALWORKING-INTENSIVE INDUSTRIES

\begin{tabular}{|c|c|}
\hline SIC Code & Industry Group and Industry \\
\hline 25 & Furniture and Fixtures \\
\hline 251 & Household Furniture \\
\hline $\begin{array}{l}2511 \\
2512 \\
2514 \\
2515 \\
2517 \\
2519\end{array}$ & $\begin{array}{l}\text { Wood Household Furniture } \\
\text { Upholstered Household Furniture } \\
\text { Metal Household Furniture } \\
\text { Mattresses and Bedsprings } \\
\text { Wood TV and Radio Cabinets } \\
\text { Household Furniture, n.e.c. }\end{array}$ \\
\hline $25 ?$ & Office Furniture \\
\hline $\begin{array}{l}2521 \\
2522\end{array}$ & $\begin{array}{l}\text { Wood Office Furniture } \\
\text { Metal Dffice Furniture }\end{array}$ \\
\hline 2531 & Public Building and Related Furniture \\
\hline 254 & Partitions and Fixtures \\
\hline $\begin{array}{l}2541 \\
2542\end{array}$ & $\begin{array}{l}\text { Wood Partitions and Fixtures } \\
\text { Metal Partitions and Fixtures }\end{array}$ \\
\hline 259 & Miscellaneous Furniture and Fixtures \\
\hline $\begin{array}{l}2591 \\
2599\end{array}$ & $\begin{array}{l}\text { Drapery Hardware and Blinds and Shades } \\
\text { Furniture and Fixtures, n.e.c. }\end{array}$ \\
\hline 33 & Primary Metal Industries \\
\hline 331 & Blast Furnace and Basic Steel Products \\
\hline $\begin{array}{l}3312 \\
3313 \\
3315 \\
3316 \\
3317\end{array}$ & $\begin{array}{l}\text { Blast Furnaces and Steel Mills } \\
\text { Electrometallurgicai Products } \\
\text { Steel Wire and Related Products } \\
\text { Cold Finishing of Steel Shapes } \\
\text { Steel Pipe and Tubes }\end{array}$ \\
\hline
\end{tabular}




\begin{tabular}{|c|c|}
\hline SIC Code & Industry Group and Industry \\
\hline 332 & Iron and Steel Foundries \\
\hline $\begin{array}{l}3321 \\
3322 \\
3324 \\
3325\end{array}$ & $\begin{array}{l}\text { Gray Iron Foundries } \\
\text { Malleable Iron Foundries } \\
\text { Steel Investment Foundries } \\
\text { Steel Foundries, n.e.c. }\end{array}$ \\
\hline 333 & Primary Nonferrous Metals \\
\hline $\begin{array}{l}3331 \\
3332 \\
3333 \\
3334 \\
3339\end{array}$ & $\begin{array}{l}\text { Primary Copper } \\
\text { Primary Lead } \\
\text { Primary Zinc } \\
\text { Primary Alumi num } \\
\text { Primary Nonferrous Metals, n.e.c. }\end{array}$ \\
\hline 3341 & Secondary Nonferrous Metals \\
\hline 335 & Nonferrous Rolling and Drawing \\
\hline $\begin{array}{l}3351 \\
3353 \\
3354 \\
3355 \\
3356 \\
3357\end{array}$ & $\begin{array}{l}\text { Copper Rolling and Orawing } \\
\text { Aluminum Sheet, Plate and Foil } \\
\text { Aluminum Extruded Products } \\
\text { Aluminum Rolling and Drawing, n.e.c. } \\
\text { Nonferrous Rolling and Drawing, n.e.c. } \\
\text { Nonferrous Wire Drawing and Insulating }\end{array}$ \\
\hline 336 & Nonferrous Foundries \\
\hline $\begin{array}{l}3361 \\
3362 \\
3369\end{array}$ & $\begin{array}{l}\text { Aluminum Foundries } \\
\text { Brass, Bronze and Copper Foundries } \\
\text { Nonferrous Foundries, n.e.c. }\end{array}$ \\
\hline 339 & Miscellaneous Primary Metal Products \\
\hline $\begin{array}{l}3398 \\
3399\end{array}$ & $\begin{array}{l}\text { Metal Heat Treating } \\
\text { Primary Metal Products, n.e.c. }\end{array}$ \\
\hline 34 & Fabricated Metal Products \\
\hline 341 & Metal Cans and Shipping Containers \\
\hline $\begin{array}{l}3411 \\
3412\end{array}$ & $\begin{array}{l}\text { Metal Cans } \\
\text { Metal Barrels, Drums and Pails }\end{array}$ \\
\hline 342 & Cutlery, Hand Tools and Hardware \\
\hline $\begin{array}{l}3421 \\
3423 \\
3425 \\
3429\end{array}$ & $\begin{array}{l}\text { Cutlery } \\
\text { Hand and Edge Tools, n.e.c. } \\
\text { Hand Saws and Saw Blades } \\
\text { Hardware, n.e.c. }\end{array}$ \\
\hline
\end{tabular}




\begin{tabular}{|c|c|}
\hline SIC Code & Industry Group and Industry \\
\hline 343 & Plumbing and Heating Except Electric \\
\hline $\begin{array}{l}3431 \\
3432 \\
3433\end{array}$ & $\begin{array}{l}\text { Metal Sanitary Ware } \\
\text { Plumbing Fittings and Brass Goods } \\
\text { Heating Equipment, Except Electric }\end{array}$ \\
\hline 344 & Fabricated Structural Metal Products \\
\hline $\begin{array}{l}3441 \\
3442 \\
3443 \\
3444 \\
3446 \\
3448 \\
3449\end{array}$ & $\begin{array}{l}\text { Fabricated Structural Metal } \\
\text { Metal Doors, Sash and Trim } \\
\text { Fabricated Parts Work (Boiler Shops) } \\
\text { Sheet Metal Work } \\
\text { Architectural Metal Work } \\
\text { Prefabricated Metal Buildings } \\
\text { Miscellaneous Metal Work }\end{array}$ \\
\hline 345 & Screw Machine Products, Bolts, etc. \\
\hline $\begin{array}{l}3451 \\
3452\end{array}$ & $\begin{array}{l}\text { Screw Machine Products } \\
\text { Bolts, Nuts, Rivets and Washers }\end{array}$ \\
\hline 346 & Metal Forgings and Stampings \\
\hline $\begin{array}{l}3462 \\
3463 \\
3465 \\
3466 \\
3469\end{array}$ & $\begin{array}{l}\text { Iron and Steel Forgings } \\
\text { Nonferrous Forgings } \\
\text { Automotive Stampings } \\
\text { Crowns and Closures } \\
\text { Metal Stampings, n.e.c. }\end{array}$ \\
\hline 347 & Metal Services, n.e.c. \\
\hline $\begin{array}{l}3471 \\
3479\end{array}$ & $\begin{array}{l}\text { Plating and Polishing } \\
\text { Metal Coating and Allied Services }\end{array}$ \\
\hline 348 & Ordnance and Accessories, n.e.c. \\
\hline $\begin{array}{l}3482 \\
3483 \\
3484 \\
3489\end{array}$ & $\begin{array}{l}\text { Small Arms Ammunition } \\
\text { Ammunition, Except for Small Arms, n.e.c. } \\
\text { Small Arms } \\
\text { Ordnance and Accessories, n.e.c. }\end{array}$ \\
\hline 349 & Miscellaneous Fabricated Metal Products \\
\hline $\begin{array}{l}3493 \\
3494 \\
3495 \\
3496 \\
3497 \\
3498 \\
3499\end{array}$ & $\begin{array}{l}\text { Steel Springs, Except Wire } \\
\text { Valves and Pipe Fittings } \\
\text { Wire Springs } \\
\text { Miscellaneous Fabricated Wire Products } \\
\text { Metal Foil and Leaf } \\
\text { Fabricated Pipe and Fittings } \\
\text { Fabricated Metal Products, n.e.c. }\end{array}$ \\
\hline
\end{tabular}




\begin{tabular}{|c|c|}
\hline SIC Code & Industry Group and Industry \\
\hline 35 & Machinery, Except Electrical \\
\hline 351 & Engines and Turbines \\
\hline $\begin{array}{l}3511 \\
3519\end{array}$ & $\begin{array}{l}\text { Turbines and Turbine Generator Sets } \\
\text { Internal Combustion Engines, n.e.c. }\end{array}$ \\
\hline 352 & Farm and Garden Machinery \\
\hline $\begin{array}{l}3523 \\
3524\end{array}$ & $\begin{array}{l}\text { Farm Machinery and Equipment } \\
\text { Lawn and Garden Equipment }\end{array}$ \\
\hline 353 & Construction and Related Machinery \\
\hline $\begin{array}{l}3531 \\
3532 \\
3533 \\
3534 \\
3535 \\
3536 \\
3537\end{array}$ & $\begin{array}{l}\text { Construction Machinery } \\
\text { Mining Machinery } \\
\text { Oil Field Machinery } \\
\text { Elevators and Moving Stairways } \\
\text { Conveyors and Conveying Equipment } \\
\text { Hoists, Cranes and Monorails } \\
\text { Industrial Trucks and Tractors }\end{array}$ \\
\hline 354 & Metalworking Machinery \\
\hline $\begin{array}{l}3541 \\
3542 \\
3544 \\
3545 \\
3546 \\
3547 \\
3549\end{array}$ & $\begin{array}{l}\text { Machine Tools, Metal Cutting Types } \\
\text { Machine Tools, Metal Forming Types } \\
\text { Special Dies, Tools, Jigs and Fixtures } \\
\text { Machine Tool Accessories } \\
\text { Power Driven Hand Tools } \\
\text { Rolling Mill Machinery } \\
\text { Metalworking Machinery, n.e.c. }\end{array}$ \\
\hline 355 & Special Industry Machinery \\
\hline $\begin{array}{l}3551 \\
3552 \\
3553 \\
3554 \\
3555 \\
3559\end{array}$ & $\begin{array}{l}\text { Food Products . Machinery } \\
\text { Textile Machinery } \\
\text { Woodworking Machinery } \\
\text { Paper Industries Machinery } \\
\text { Printing Trades Machinery } \\
\text { Special Industry Machinery, n.e.c. }\end{array}$ \\
\hline 356 & General Industrial Machinery \\
\hline $\begin{array}{l}3561 \\
3562 \\
3563 \\
3564 \\
3565 \\
3566\end{array}$ & $\begin{array}{l}\text { Pumps and Pumping Equipment } \\
\text { Ball and Roller Bearings } \\
\text { Air and Gas Compressors } \\
\text { Blowers and Fans } \\
\text { Industrial Patterns } \\
\text { Speed Changers, Drives and Gears }\end{array}$ \\
\hline
\end{tabular}




\begin{tabular}{|c|c|}
\hline SIC Code & Industry Group and Industry \\
\hline $\begin{array}{l}3567 \\
3568 \\
3569\end{array}$ & $\begin{array}{l}\text { Industrial Furnaces and Ovens } \\
\text { Power Transmission Equipment, n.e.c. } \\
\text { General Industrial Machinery, n.e.c. }\end{array}$ \\
\hline 357 & Office and Computing Machines \\
\hline $\begin{array}{l}3573 \\
3574 \\
3576 \\
3579\end{array}$ & $\begin{array}{l}\text { Electronic Computing Equipment } \\
\text { Calculating and Accounting Machines } \\
\text { Scales and Balances, Except Laboratory } \\
\text { Office Machines, n.e.c. and Typewriters }\end{array}$ \\
\hline 358 & Refrigeration and Service Machinery \\
\hline $\begin{array}{l}3581 \\
3582 \\
3585 \\
3586 \\
3589\end{array}$ & $\begin{array}{l}\text { Automatic Merchandising Machines } \\
\text { Commercial Laundry Equipment } \\
\text { Refrigeration and Heating Equipment } \\
\text { Measuring and Dispensing Pumps } \\
\text { Service Industry Machinery, n.e.c. }\end{array}$ \\
\hline 359 & Miscellaneous Machinery, Except Electrical \\
\hline $\begin{array}{l}3592 \\
3599\end{array}$ & $\begin{array}{l}\text { Carburetors, Pistons, Rings and Vaives } \\
\text { Machinery, Except Electrical, n.e.c. }\end{array}$ \\
\hline 36 & Electric and Electronic Equipment \\
\hline 361 & Electric Distributing Equipment \\
\hline $\begin{array}{l}3612 \\
3613\end{array}$ & $\begin{array}{l}\text { Transformers } \\
\text { Switchgear and Switchboard Apparatus }\end{array}$ \\
\hline 362 & Electrical Industrial Apparatus \\
\hline $\begin{array}{l}3621 \\
3622 \\
3623 \\
3624 \\
3629\end{array}$ & $\begin{array}{l}\text { Motors and Generators } \\
\text { Industrial Controls } \\
\text { Welding Apparatus, Electric } \\
\text { Carbon and Graphite Products } \\
\text { Electrical Industrial Apparatus, n.e.c. }\end{array}$ \\
\hline 363 & Household Appliances \\
\hline $\begin{array}{l}3631 \\
3632 \\
3633 \\
3634 \\
3635 \\
3636 \\
3639\end{array}$ & $\begin{array}{l}\text { Household Cooking Equipment } \\
\text { Household Refrigerators and Freezers } \\
\text { Household Laundry Equipment } \\
\text { Electric Housewares and Fans } \\
\text { Household Vacuum Cleaners } \\
\text { Sewing Machines } \\
\text { Household Appliances, n.e.c. }\end{array}$ \\
\hline
\end{tabular}




\begin{tabular}{|c|c|}
\hline C Code & Industry Group and Industry \\
\hline 364 & Electric Lighting and Wiring Equipment \\
\hline $\begin{array}{l}3641 \\
3643 \\
3644 \\
3645 \\
3646 \\
3647 \\
3648\end{array}$ & $\begin{array}{l}\text { Electric Lamps } \\
\text { Current-Carrying Wiring Devices } \\
\text { Noncurrent-Carrying Wiring Devices } \\
\text { Residential Lighting Fixtures } \\
\text { Commercial Lighting Fixtures } \\
\text { Vehicular Lighting Equipment } \\
\text { Lighting Equipment, n.e.c. }\end{array}$ \\
\hline 365 & Radio and TV Receiving Equipment \\
\hline $\begin{array}{l}3651 \\
3652\end{array}$ & $\begin{array}{l}\text { Radio and TV Receiving Sets } \\
\text { Phonograph Records and Prerecorded Tape }\end{array}$ \\
\hline 366 & Communications Equipment \\
\hline $\begin{array}{l}3661 \\
3662\end{array}$ & $\begin{array}{l}\text { Telephone and Telegraph Apparatus } \\
\text { Radio and TV Communication Equipment }\end{array}$ \\
\hline 367 & Electronic Components and Accessories \\
\hline $\begin{array}{l}3671 \\
3674 \\
3675 \\
3676 \\
3677 \\
3678 \\
3679\end{array}$ & $\begin{array}{l}\text { Electron Tubes, All Types } \\
\text { Semiconductors and Related Devices } \\
\text { Electronic Capacitors } \\
\text { Electronic Resistors } \\
\text { Electronic Coils and Transformers } \\
\text { Electronic Connectors } \\
\text { Electronic Components, n.e.c. }\end{array}$ \\
\hline 369 & Miscellaneous Electric Equipment and Supplies \\
\hline $\begin{array}{l}3691 \\
3692 \\
3693\end{array}$ & $\begin{array}{l}\text { Storage Batteries } \\
\text { Primary Batteries, Dry and Wet } \\
\text { X-ray, Electromedical, and Electrotherapeut ic } \\
\text { Apparatus }\end{array}$ \\
\hline $\begin{array}{l}3694 \\
3699\end{array}$ & $\begin{array}{l}\text { Engine Electrical Equipment } \\
\text { Electrical Equipment and Supplies, n.e.c. }\end{array}$ \\
\hline 37 & Transportation Equipment \\
\hline 371 & Motor Vehicles and Equipment \\
\hline $\begin{array}{l}3711 \\
3713 \\
3714 \\
3715 \\
3716\end{array}$ & $\begin{array}{l}\text { Motor Vehicles and Car Bodies } \\
\text { Truck and Bus Bodies } \\
\text { Motor Vehicle Parts and Accessories } \\
\text { Truck Trailers } \\
\text { Motor Homes Produced on Purchased Chassis }\end{array}$ \\
\hline
\end{tabular}




\begin{tabular}{|c|c|}
\hline SIC Code & Industry Group and Industry \\
\hline 372 & Aircraft and Parts \\
\hline $\begin{array}{l}3721 \\
3724 \\
3728\end{array}$ & $\begin{array}{l}\text { Aircraft } \\
\text { Aircraft Engines and Engine Parts } \\
\text { Aircraft Equipment, n.e.c. }\end{array}$ \\
\hline 373 & Ship and Boat Building and Repairing \\
\hline $\begin{array}{l}3731 \\
3732\end{array}$ & $\begin{array}{l}\text { Ship Building and Repairing } \\
\text { Boat Building and Repairing }\end{array}$ \\
\hline 3743 & Railroad Equipment \\
\hline 3751 & Motorcycles, Bicycles and Parts \\
\hline 376 & Guided Missiles, Space Vehicles and Parts \\
\hline $\begin{array}{l}3761 \\
3764 \\
3769\end{array}$ & $\begin{array}{l}\text { Guided Missiles and Space Vehicles } \\
\text { Space Propulsion Units and Parts } \\
\text { Space Vehicle Equipment, n.e.c. }\end{array}$ \\
\hline 379 & Miscellaneous Transportation Equipment \\
\hline $\begin{array}{l}3792 \\
3795 \\
3799\end{array}$ & $\begin{array}{l}\text { Travel Trailers and Campers } \\
\text { Tanks and Tank Components } \\
\text { Transportation Equipment, n.e.c. }\end{array}$ \\
\hline 38 & Instruments and Related Products \\
\hline 3811 & Engineering and Scientific Instruments \\
\hline 382 & Measuring and Controlling Devices \\
\hline $\begin{array}{l}3822 \\
3823 \\
3824 \\
3825 \\
3829\end{array}$ & $\begin{array}{l}\text { Envi ronmental Controls } \\
\text { Process Control Instruments } \\
\text { Fluid Meters and Counting Devices } \\
\text { Instruments to Measure Electricity } \\
\text { Measuring and Controlling Devices, n.e.c. }\end{array}$ \\
\hline 3832 & Optical Instruments and Lenses \\
\hline 384 & Medical Instruments and Supplies \\
\hline $\begin{array}{l}3841 \\
3842 \\
3843\end{array}$ & $\begin{array}{l}\text { Surgical and Medical Instruments } \\
\text { Surgical Appliances and Supplies } \\
\text { Dental Equipment and Supplies }\end{array}$ \\
\hline 3851 & Ophthalmic Goods \\
\hline
\end{tabular}

\section{A. 7}




\begin{tabular}{|c|c|}
\hline SIC Code & Industry Group and Industry \\
\hline 3861 & Photographic Equipment and Supplies \\
\hline 3873 & Watches, Clocks and Watchcases \\
\hline 39 & Miscellaneous Manufacturing Industries \\
\hline 391 & Jewelry, Silverware and Plated Ware \\
\hline $\begin{array}{l}3911 \\
3914 \\
3915\end{array}$ & $\begin{array}{l}\text { Jewelry, Precious Metal } \\
\text { Silverware and Plated Ware } \\
\text { Jewelers' Materials and Lapidary work }\end{array}$ \\
\hline 3931 & Musical Instruments \\
\hline 394 & Toys and Sporting Goods \\
\hline $\begin{array}{l}3942 \\
3944 \\
3949\end{array}$ & $\begin{array}{l}\text { Dolls } \\
\text { Games, Toys and Childrens' Vehicles } \\
\text { Sporting and Athletic Goods, n.e.c. }\end{array}$ \\
\hline 395 & Pens, Pencils and Office and Art Supplies \\
\hline $\begin{array}{l}3951 \\
3952 \\
3953 \\
3955\end{array}$ & $\begin{array}{l}\text { Pens and Mechanical Pencils } \\
\text { Lead Pencils and Art Goods } \\
\text { Marking Devices } \\
\text { Carbon Paper and Inked Ribbons }\end{array}$ \\
\hline 396 & Costume Jewelry and Notions \\
\hline $\begin{array}{l}3961 \\
3962 \\
3963 \\
3964\end{array}$ & $\begin{array}{l}\text { Costume Jewelry } \\
\text { Artificial Flowers } \\
\text { Buttons } \\
\text { Needles, Pins and Fasteners }\end{array}$ \\
\hline 399 & Miscellaneous Manufactures \\
\hline $\begin{array}{l}3991 \\
3993 \\
3995 \\
3996 \\
3999\end{array}$ & $\begin{array}{l}\text { Brooms and Brushes } \\
\text { Signs and Advertising Displays } \\
\text { Burial Caskets } \\
\text { Hard Surface Floor Coverings } \\
\text { Manufacturing Industries, n.e.c. }\end{array}$ \\
\hline
\end{tabular}


APPENDIX B

SPINDLE DRIVE HORSEPOWER OF SELECTED METALWORKING MACHINES 
Appendix B: Spindle Drive Horsepower of Selected Metalworking Machines

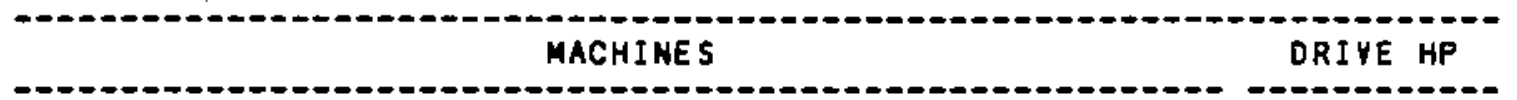

1. METALCUTTING MACHINES

\subsection{HC TURNIHG MACHINES}

-Horizontal under 9 n chuck

- Cincinnati M11. 2-Axfs Machine CINTURN Sertes 1208/1210C

- Cincinnati Mil. 2-Axis Machine CINTURN Series $1208 / 1210 U$

- HITACHI SEIKI NS-A2 Turning Center

- Hardinge Brothers Inc. SuperSlant

- Fujf Machine Mfg. Co. Model SN

- Fujl Machine Mfg. Co. Model KN

-Horlzontal 9" to under 13 " chuck

- Cincinnati Mil. 2-Axis Machine CINTURN Ser1es 1212C 30

- Cincinnati Hil. 2-Axis Machine CINTURN Series $1212 \mathrm{U}$

- Cincinnati Mil. CINTURH 2-Axis CNC Chucking Ctr Model $12 \quad 50$

- Cincinnati Hi1. CINTURA 4-Axis CNC Chckng Ctr Mode] I2CD 50

- Hortizontal 13: to under 20" chuck

- Cincinnat1 Mi1. CINTURN 2-Axis Chucking Ctr Model 18C

- Cincinnat1 Młi. CINTURN 2-Axis Chucking Ctr Mode] 15C

- Cincinnati M11. CINTURN 2-Ax1s CNC Trng Ctr Un. Mod. 15U

- Cincinnati M11. CINTURh 2-Axis CNC Trng Ctr Un. Mod. IBU

- Cincinnati M11. CINTURN 4-Axis CNC Chckng Ctr Model 15CD

- Cincinnati Mi\}. CINTURN 4-Axis CNC Chekng Ctr Hodel 18CD

- HITACHI SEIKI NS-S3 Turning Center

- Leblond Makino Mach. Tool Co. CNC Turn. Center Baron 25

-Horfzontal 20" chuck and larger

- Cincinnati Mil. CINTURN 2-Axis CNC Turning Center M-28ST

- Cincinnati M11. CINTURN 2-Axis CNC Ctr Chckng Mod. 28STC

- Cincinnat 1 Mil. CINTURN 2-Ax1s CNC Ctr Chckng Mod. 365TC

- Cincinnati Mfl. CINTURN 2-Axis CNC Trng Ctr Un. Mod. 2lU

- Cincinnati Mil. CINTURN 2-Ax1s CNC Trng Ctr Un. Mod. $24 U$

- Cincinnati Mil. CINTURN 2-Axis CNC Trng Ctr Un. Mod. 28U

- Leblond Makino Mach. Tool Co. CHC Turn. Center Baron 40

- Leblond Makino Mach. Tool Co. CNC Turn. Center Baron 60

- RDsD Corp. Machine Tool Div. High HP Roll Turning Lathe

-Vertfcal turn a bore (VTM, VBM)

- MFL Machine Toot Ine.

- S\& S Machinery Co. Superaill CNC 40

- $S$ \& S Machinery Co. Supermill CNC 60

- S \& Machinery Co. Superaili CNC 72 
Appendix B: (contd)

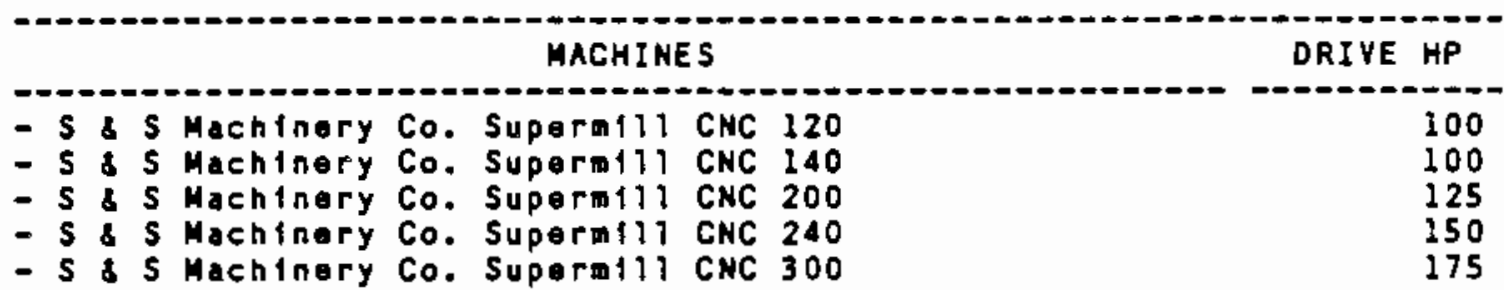

\subsection{NON NC TURNING MACHINES}

-Eng \& tlra (not tracer) over 8" to 16 " swing

- SIgMA Machinery Inc. Model SH40-16"

* Nardini International Inc. Model TT-1000S/E 10n

- Nardini International Inc. Model TT-1200S/E 12"

- S \& S Machinery. Co. Lansing Gap Bed Lathe Model 15P 15"

- S \& S Machinery Co. Lansing Gap Bod Lathe Modol 16T 16"

- S \& S Machinery Co. Lansing Gap Bed Lathe Model 18T 16"

- Intermark Martford Corp. Precision Lathe Model $143014 n$

- Polamco Model Tumb 14 "

7.5

1.5

1.5

5

10

10

-Eng t tlra (not tracer) over 16* swing

- SIgMa Machinery Inc. Mdel SN63-25"

- SIGMA Machinery Inc. SIGMA-YOLMAN Eng. Lathe Type SUloo

- S \& S Machinery Co. Lansing Gap Bed Lathe Modei IBG 18"

- Polamco Tarnor TUJ 50 m $22^{\prime \prime}$

- Polanco Model TUG40 $17 \pi$

- Pol amco Model TUGas $19 n$

- Polameo Model Tuj5o 21"

- Polamco Model TUR5O H.D. 20 n

- Polameo Model TUR63A $25 n$

- Polamco Model TPL90 $36 "$

-Tracer lathes (all stzes)

- S \& S Machinery Co. Lansing G Facing Tracing Lathe 52"

- S \& S Machinery Co. Lansing G Facing Tracing Lathe 60"

- S s S Machinery Co. Lansing G Facing Tracing Lathe B2"

- S \& S Machinery Co. Lansing G Facing Tracing Lathe 120"

-Turret lathes (al) non-NC)

- SIgMA Machinery Ine. SIGMA-TOS Ram Type 44 model SR50

-Yertfcal turning and boring wills (YTM,YeM)

- SIgMA Mach. Inc. SIgma-tos YBTM Type SKOIZ

-Hor1z, boring, drilling \& willing (bar wachining) 
Appendix B: (contd)

- DECKEL FP4NC Universal Milling \& Boring Machino 5.5

- DECKEL FP5NC Universal Mililing \& Boring Machine

- Motar Machine Tools Model $875 / 105$ MNC

- Wotan Machine Tools Model B 75/150 SNC

- Motan Mechine Tools Model B 105 MNC 20

Wotan Machine Tools Model B 120 MNC

- Motan Machine Tools Model Rapld IR/6

- Notan Machine Tools Model B 75 Tel. 1

- Motan Machine Tools Model B 75/105 Tel. 1

- Wotan Machine Tools Model B 75/120 Tel. I

\subsection{MON MC BORING MACHINES}

-Hor, bore, arill, will (bar mach) table a planer type

- SIGMA Mach. Ine. SIGMA-TOS Type nh63, 2-1/2" bar

- SIGMA Mach. Inc. SIGMA-TOS Type M9A, 3-1/2" bar

-Hor. bore, drill, w111 (bar mach) floor type

- SIGMA Mach. Inc. SIgMA-TOS Typo WHA 13

- SIgMA Mach. InC. SIGHA/SKODA Heary duty HBM

-Precison, horfzontal and vertical

- SIGMA Mach. Ine. SIGMA-TOS VTM type SJK lOB (50" soling)

- SIgMA Mach. Inc. SIGMA-TOS VTM Type SKJ 20 (90N swing)

1.5 NON MC ORILLING MACHINES

- Vertical upright, hand or pover feed

- Jacobson Tool \& Mfg Co. Model 75H Drifl-0-Matic

$-\operatorname{Rad} 1 \mathrm{al}$

- SIGMa Mach. Inc. SIgma-mas Type roso

- SIgMA Mach. Inc. SIGMA-MAS Type YRMSOA

- DoAll Model D-50LOOR

\subsection{NC MACHINING CENTERS}

-Automatic tool change: vertical Y-axis 26" or less

- Cincinnati Hil. CINTIMATIC 5YC Mode] $750 \quad(Y=20 \%)$

- Cincinnat1 Mil. CINTIMATIC 20VC Modei $2000 \quad(Y=25 \mathrm{~m})$

- Hurco Mfs. Co. Hurco MD3 ( $Y=20$ )

- Hurco mfg. Co. Hurco MDI $(Y=16 \mathrm{~N})$

- MOOG InC Model 83-3000MC $\left(Y=10^{n}\right)$

$$
\text { -Automatic tool change: vertical Y-axis over } 26 \text { " }
$$




\section{Appendix B: (contd)}

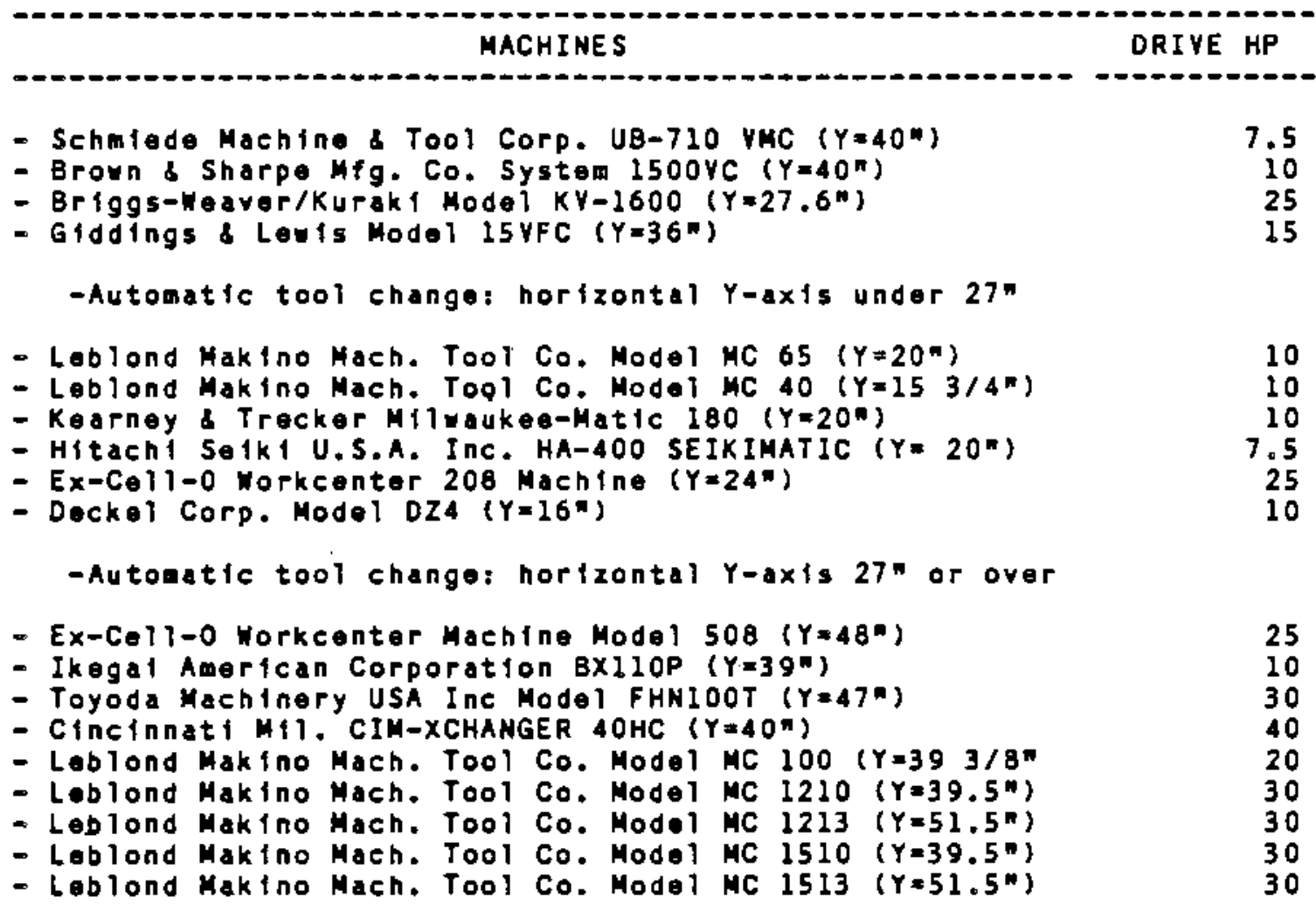

\subsection{NC MILLING MACHINES}

\section{-Proffling and duplicating}

- Leblond Makino Mach. Tool Co.

- Leblond Makino Mach. Tool Co.

- Loblond Makino Mach. Tool Co.

- Leblond Makino Mach. Tool Co.

- Loblond Makino Mach. Tool Co.

- Leblond Makino Mach. Tool Co.

- Leblond Makino Mach. Tool Co.

- Leblond Makino Mach. Tool Co.

- Lobiond Makino Mach. Tool Co.

$\begin{array}{ll}\text { Model FDl06 (Yertical) } & 15 \\ \text { Model FD128 (Yertical) } & 25 \\ \text { Model FDI78 (Yertical) } & 25 \\ \text { Model FD220 (Yertical) } & 25 \\ \text { Model H1210 (Hortzontal) } & 30 \\ \text { Model H1710 (Horizontal) } & 30 \\ \text { Model H2210 (Horizontal) } & 30 \\ \text { Model H2213 (Horizontal) } & 30 \\ \text { Model H2513 (Horlzontal) } & 30\end{array}$

1.8 NON NC MILLING MACHINES

-General purpose. knee or bed: vertical

- SIgMA Mach. Inc. SIgMA-TOS Type FA3AY

- SIgMA Mach. Inc. SIGMA-TOS Type FA4AY

- Hurco Manufacturing Company Inc. Model SMl

- Hurco Manufacturing Company Inc. Modol Sh2

-General purpose, knee or bed: herlzontal 
Appendix B: (contd)

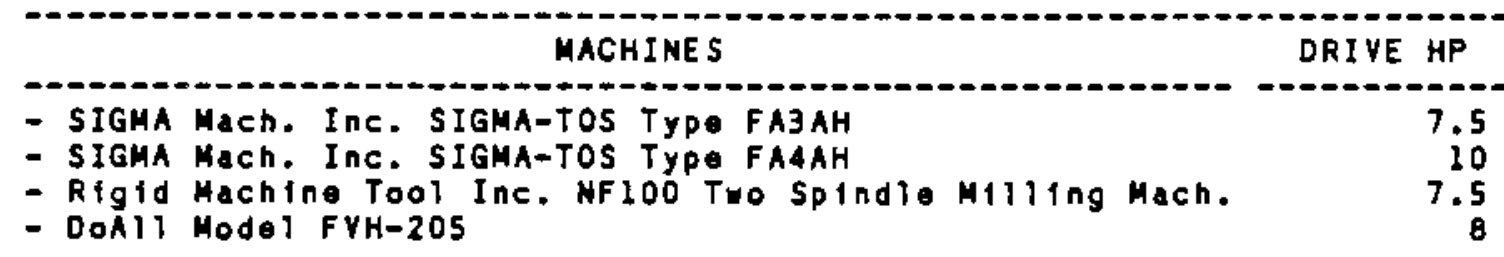

-Automatic and manufacturing

- SIgMA Mach. Inc. Typo FDadr 22.5

-Profiling and dupplicating

- Oroop \& ReIn Model FS $2255 \mathrm{kc} \quad 20$

-Dfe sinking, engraving, pantograph

- Cincinnati Milacton 28" Vertical. HYDRO-TEl 15

1.9 geAR CUTTING AND FINISHING MACHINES

-Gear hobbers

- SIGMA Mach. Inc. SIGMA-YOLMAN 71" Un1v. GHM, Type OFI6 37

- Sigma Mach. Inc. SIGMA-Yolman 28" Univ. GHM, Type OF71 24

- SIgMa Mach. Inc. SIGMA-Yolman 43" Unir. GHM. Typo OFIO

-Goar shapers

- SIGMA Mach. Inc. SIGMA-TOS Typo OHO2O

- SIGMA Mach. Inc. SIGMA-TOS Typa OHO5O

- S S Machinery Co. Lansing Gear Shaping Machine Mod. 6

- S \& S Machinery Co. Lansing Gear Shaping Machine Mod. 4

- S s Machinery Co. Lansing Gaar Shaping Machine Mod. 3

-Gar tooth finish (grinding, lap, shave etc.)

- Hay Machine Tools Inc. Hey Mo. $10 \quad 1.5$

1.10 NC GRINOING MACHINES (ALL TYPES)

- Bryant Grinder Corp. Lectraline LLl

- Bryant Grinder Corp. Lectraline LL2

- Bryant Grinder Corp. Lectraline LL3

- Bryant Grinder Corp. Lectraline LL3-55

- Bryant Grinder Corp. Lactraline LLA

- Cincinnati Milacron Centerless Grid. Mach. Mod. Ae 220-8

- Cincinnati Milacron Centerless Grdg Mach. Mod. AE 220-12

- Cincinnati Mqlacron Centerless Grdg Mach. Mod. AE 330-15

- Cincinati Milacron Centerless Grdg Mach. Mod. AE 350-20

3.5

5.5

1.11 NON NC GRINDING MACHINES

-External: plain conter typo

0.75

1.5 
Appendix B: (contd)

MACHINES

DRIVE HP

- SIgMa Mach. Inc. Sigma-tos Super Prec. Univ. Type gualga

- Cincinnati Milacron Plain Grinding Machine 14"

- Cincinnati Milacron Plaín Series 370

- Cincinnati Milacron Plaín Sertes 380

External: unfversal center type

- SIgma Mach. Inc. SIgma-Tos Hydr. Universal Typo bu 28

- Polamco / jote. Schaudt Univ. Cylindrical Mod. A-440N

-External: centeriess (inciuding shoe typo)

- Cincinnati Milacron Model CINCO 15

- Cincinnati Milacron CENTURAMIC 200 Series

- ESTARTA y ECENARRo Modol eSTARTA.327

- estarta y eCEnarro Model estarta ee 301

- ESTARTA y ECEnARRo Model estaRTa eE 312

- ESTARTA y ECEnARRo Model ESTARTA Ee 320

- ESTARTA y ECENARRo Model ESTARTA EE 322

- ESTARTA Y ECENARRo Model ESTARTA Ee 325

- estarta y ecenarRo Model estarta eE 327

- ESTARTA Y ECENARRo Modol ESTARTA Ee 330

-Extornal: chucking

- Cincinnat 1 Milacron Chicking Grinding Machino Ho. I

- Cincinnati Milacron Chicking Grinding Machine No. 2

-Surface: rotary table, horizontal and vartical

- Cincinnati Milacron Model 161

- S\& S Machinery Co. Elgin Model RTC 500

-Surface: reciprocating, vertical and horizontal, porer

- SIGMA Mach. Inc. Auto. Hydr. Surf. Grinder Type BPh320A

- SIgMa Mach. Inc. Auto. Hydr. Surf. Grinder Type BRH $20 \mathrm{~A}$

- SIgMA Mach. Inc. Auto. Hydr. Surf. Grinder Type BRH 40A

- DoAll Model D824-12

- Polanco Model FNC-25

-Tool and cutter

- Sigma mach.inc. Typo Bhjoza/AS

- SIgma Mach.Inc. Type BN102B

- Cincinati Milacron Hodel Mo. 2MT

- Intermark Hartford Corp

- Polarco Model NUA-25H

1.2

1.2

-Bench, floor and snag 
Appendix B: (contd)

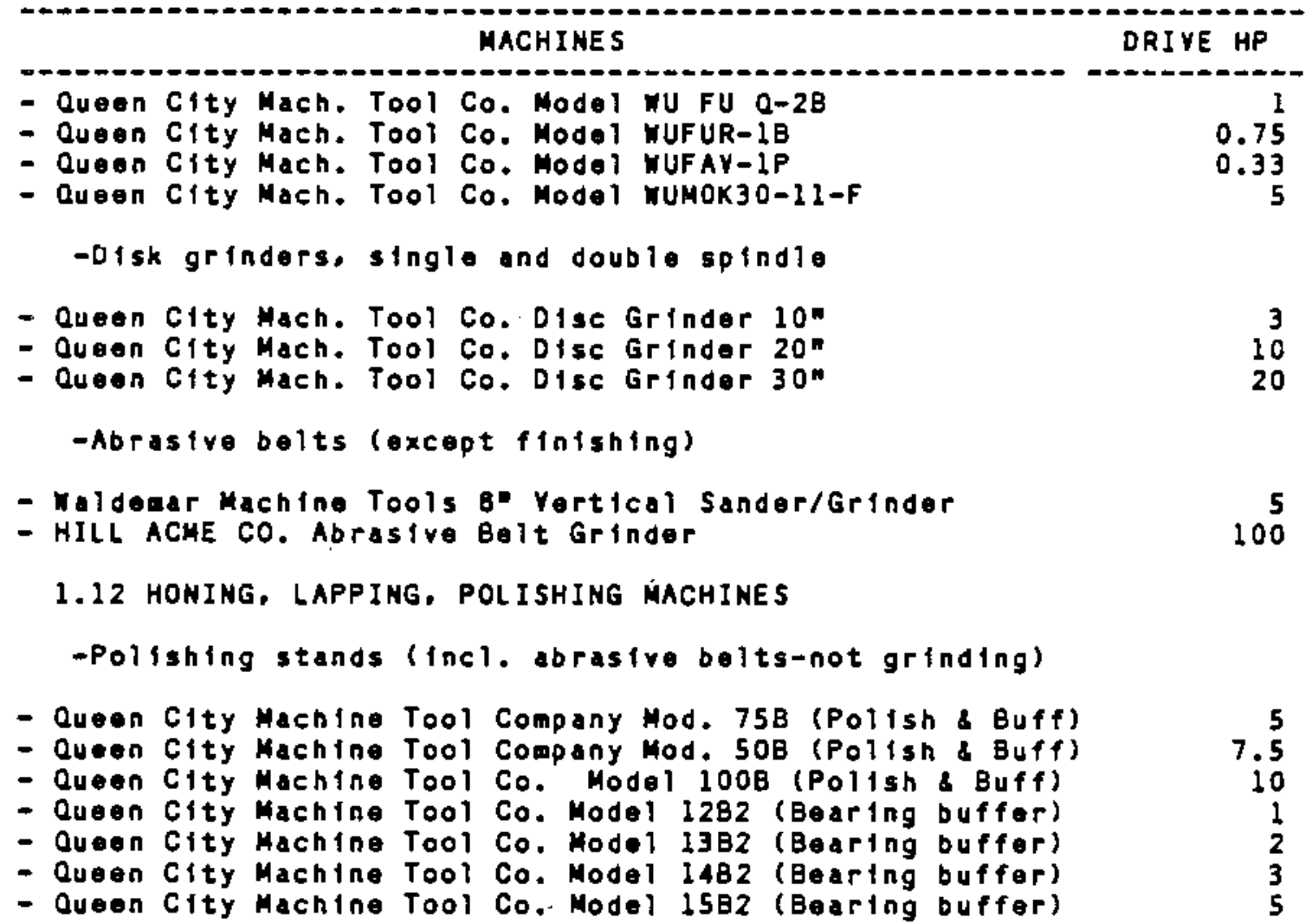

\subsection{THREADING MACHINES}

- Teledyne Landis Machine Model 10/16B 4

\subsection{CUTOFF AND SAMING MACHINES}

-Kacksaus

- DoAll Model C-3232M Cut-off Pover Say

- DoAll Model AC-20l6 Aluminum Cut-Off Sav

- Abrasive weels

- J. J. Savage Co. Inc. Sever-All Model I-B

- W. J. Sarage Co. Inc. Savage/Campbeli Model 2

- W. J. Sarage Co. Inc. Saraga/Campbell Model 102 A

- W. J. Sarage Co. Inc. Sarage/Canpbell Model 223

- W. J. Sarage Co. Inc. Sarage/Campbell Model 265

- H. J. Sarage Co. Inc. Sarage/Campbell Model 270

- H. J. Sarage Co. Inc. Sarage/Campbell Model 302

- M. J. Sarage Co. Inc. Saraga/Campbell Model 476

- W. J. Sarage Co. Inc. Sarage/Campoell Model 342

- W. J. Sarage Co. Inc. Sarage/Campbell Model 364 
Appendix B: (contd)

MACHINES

- W. J. Sarage Co. Inc. Saraga/Campbell Model 406

- H. J. Sarage Co. Inc. Sarago/Campoell Model 481

- J. J. Sarago Co. Inc. Savage/Campbell Model 612

- W. J. Sarage Co. Inc. Sever-All Model 1-B4

- W. J. Sarage Co. Inc. Sever-All Model 52-A

- W. J. Sarage Co. Inc. Sever-All Model 22-A

- J. Javago Co. Inc. Abrasive Plate Sar Model WJs-10

- W. Javage Co. Inc. Abrasive Plate Sar Model HJS-20

- J. J. Savage Co. Inc. Abrasive Plate Say Model Wus-3o

- W. J. Sarago Co. Inc. Abrasive Plate Sar Model MJS-40

-Band says, countour saring and fliting

- DoAli Model C-1220A

- DoAll Model C-1216a pover Sar

- DoAll Model C-916

- DoAl1 Model 2612-015

- DoAl1 Model 3613-1

- DoAll Model 2613-3

- HeM Inc. Hesm Say Model 500

- HeM Inc. HEsm Say Model 750

- HEM Ine. HEsM Saw Model 1000A

- HEM Inc. HESM Sar Model 1000AH

- HeM InC. HESM Sar Modol 1200A

- HeM Inc. HEsM Say Model 1200LA

- HEM Inc. HESM Sar Modol l250RB

- HEM Inc. HESH Sar Modol 1500A

DRIYE HP

\section{METALFORMING MACHINES}

\subsection{PUNCHING AND SHEARING MACHINES}

- NC shearing aachines

- Muller-Hiengarten AG Segment Motching Mach. Type NNS1-16

2.2 NON NC PUNCHING \& SHEARING MACHINES

-Punching aachines (incl. comb. punching s shearing)

- Japan Automatic Machine Co. Model BPN100S IT

- Japan Automatic Machine Co. Model BPN3005 $3 T$

- Japan Automatic Machine Co. Model BPN505L 5T

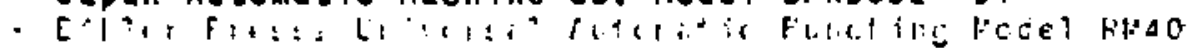

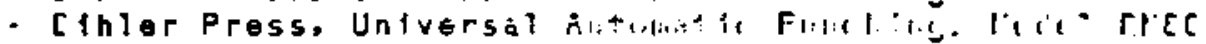

- Binler Press, Universal Automotic Punching Model GRMioo

-Plate and sheet shears: mechantcal

- Boschert GmbH Model PNA Notcher \& shearer 
Appendix B: (contd)

\begin{tabular}{ll} 
& \\
\hline &
\end{tabular}

\subsection{NON NC BENDING AND FORMING MACHINES (POMER)}

-Press brakes: mechantcal

- Rousselie Prosses Inc. Heary Duty OBS L1ne Model G50 50T

- Rousselle Presses Inc. Heavy Duty OBS Line Model G65 65T

- Roussel1. Prosses Inc. Heary Duty OBS Model Gllo $110 T$

- Roussolia Presses Inc. Heavy Duty OBS Modet G135 135T

- Roussolle Prosses Inc. Heavy Duty OBS Model GI75 175T

-Press brakes: hydroulfic and pnoumatic

- Rousselie Presses Inc. Model H25-4 25T

- Rousselle Presses Inc. Model H40-4 $40 \mathrm{~T}$

- Rousselle Presses Inc. Model H90-12 90T

- Rousselle Presses Inc. Modol H35-12 135T

- Comeq Inc / Goka MIcrocrop-36 Hydraulic Ironvorker

-Bending rolls, sheet and plate

- The Lockformer Co. Lockformer Model L-g

- The Lockformer Co. Lockformer Model L-7

- The Lockformer Co. Lockformer Model L-100S

- The Lockformer Co. Lockformer Model L-I4DS

- The Lockformer Co. Lockformer Model L-IGDS

- Maldemar Machine Tools. Plate Bending Roll Model 16-6

- Maldemar Machine Tools. Plate Bending Roll Model 10-8

- Maldenar Machine Tools. Plate Bending Roll Model 20-6

- Maldenar Machine Tools. Plate Bending Roll Model 16-8

- Maldemar Machine Tools. Plate Bending Roll Model 14-10

- Maldemar Machine Tools. Plate Bending Roll Model 32-6.

- Waldemar Machine Tools. Plate Bending Roll Model 24-8

- Madenar Machine Tools, Plate Bending Roll Model 20-10

- Waldemar Machine Tools. Plate Bending Roli Model 48-6

- Maldemar Machine Tools. Plate Bending Roli Model 48-8

- Maldemar Machine Tools. Plate Bending Roll Model 36-10

-Bending rolis, angles, bars,shapes pipes

- Comeq. Ine / Roundo Model R2 
Appendix B: (contd)

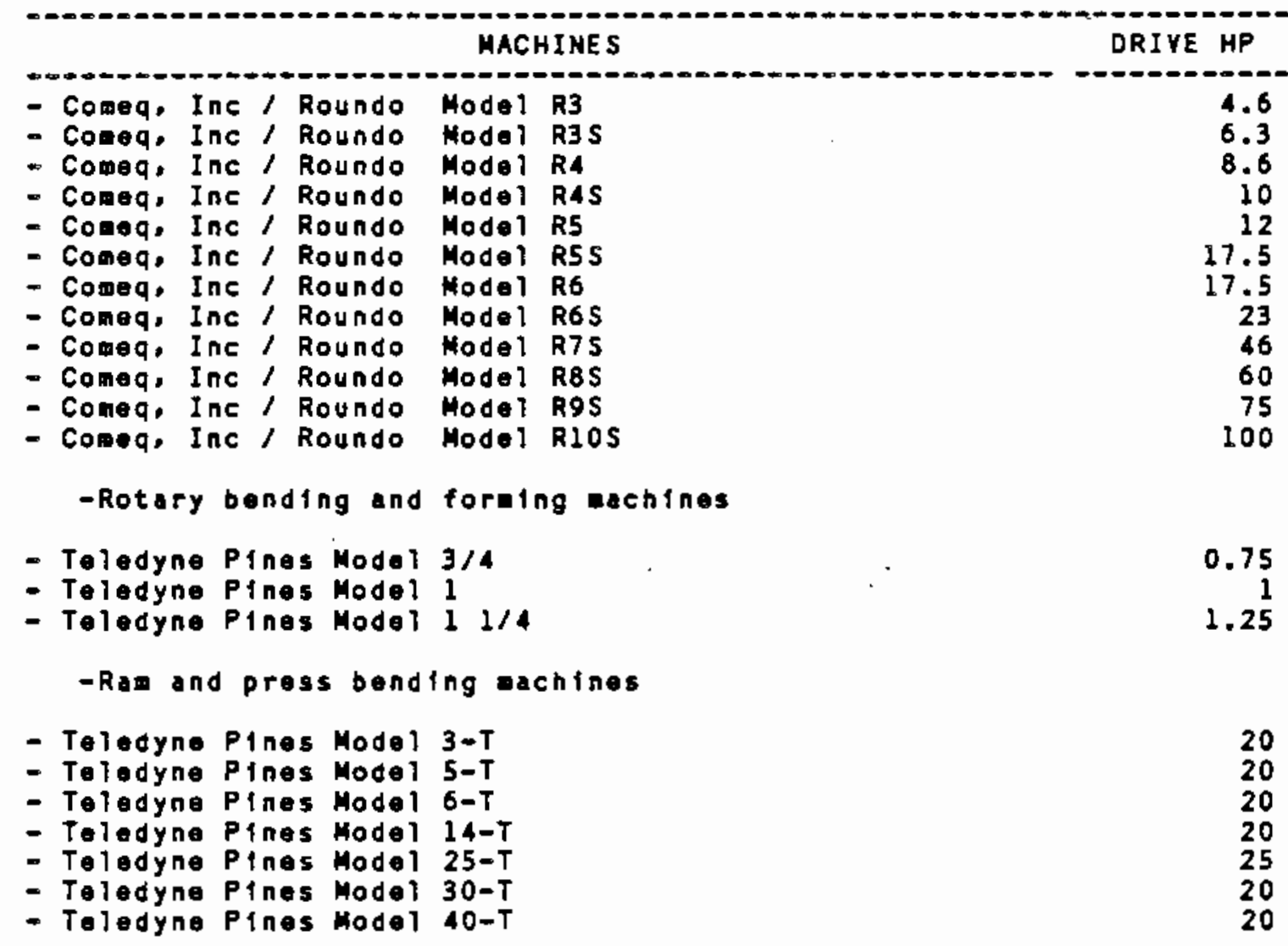

\subsection{MECHANICAL PRESSES-POMER (NOT FORGE5)}

-Open back (OBI) \& gap: 51 tons and over

- Roussella Presses Moder G2-150 150T 15

- Rousselle Prasses Model G2-200 200T 20

- Rous5e11e Prosses Model G2-250 250T 25

- Roussello Presses Model G2-300 300T 30

-Vertical straight side or arch: single polnt

- Oak Products Inc. H1gh Speed Press 30T 10

- Oak Products Inc. High Speed Pross 60T 15

- Ferro Tool Inc/ Gedr. Edelhoff GmbH Model DEPSR 63T

- Ferro Tool Incl Gebr. Edelhoff GmbH Model DEPSR 75T 7.5

- Ferro Tool Inc/ Gebr. Edelhoff GmbH Model DEPRR 100T.

- Oak Products Inc. High Speed Press 100T 25

- Forro Tool Inc/ Gebr. Edelhoft GabH Model DEPRR 130T

- Oak Produets Inc. High Speed Press $150 T$

- Ferro Tool Inc/ Gedr. Edelhoft GabH Model DEPRR 160T 20

- Oak Products Inc. HIgh Speod Press 200T 40

- Ferro Tool Inc/ Gedr. Edelhoff GmbH Model DEPRR 200T 20

- Ferro Tool Inc/ Gebr. Edelhoff GabH Model DEPRR 250T 25 
Appendix B: (contd)

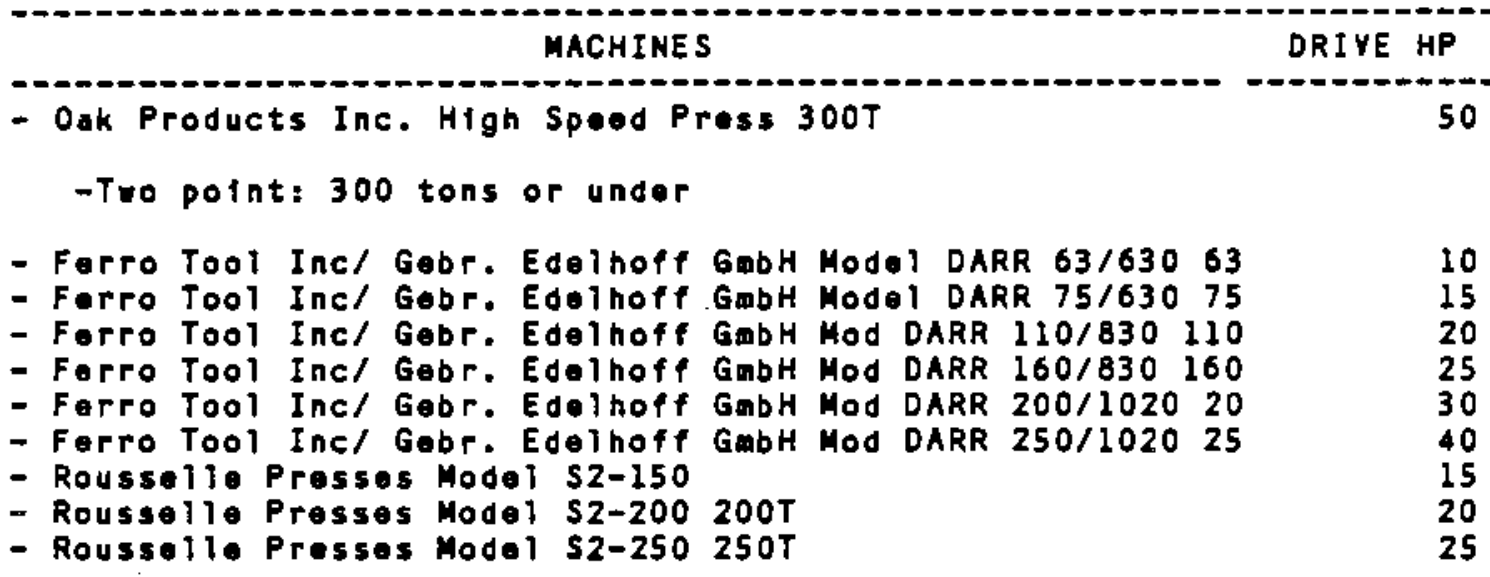

-Tro polnt: 301 tons or over

- Forro Tool Incl Gobr. Edelhoff GabH Mod DARR $320 / 102032$

- Rousselie Presses Model S2-300 300T 30

\subsection{HYDRAULIC PRESSES (NOT FORGES)}

-Yertical, strafght side, or column

- Dake Corporation Die Try-out press Model 18-350 25T 10

- Dake Corporation Die Try-out press Model 18-359 25T 10

- Dake Corporation Die Cast Triaming press Mod. 27-320 25T 15

- Dake Corporation Model 27-410 25T 15

- Laufer Prosses Ine. Fast Aeting pross Type RPT $2525 T$

- Dake Corporation D1e Try-out press Model 18-351 50T

- Dake Corporation Model 27-411 50T

- Lauffer Presses Inc. Fast Acting press Type RPT $6361 T$

- Dake Corporation Model 27-412 75T 15

- Lauffer Prosses Inc. Fast Acting pross Typo RPT $160176 \mathrm{~T}$

- Dake Corporation Model 27-413 100T 20

- Dake Corporation Model 27-414 $150 T$

- Dake Corporation Dio Cast Triming press M. 27-324 150T 20

- Dake Corporation Model 27-415 200T 40

- Dake Corporation Die Cast Trianing press M. 27-325 200T 30

- Dake Corporation Model 27-416 $300 T$ To

- Dake Corporation Die Cast Trfmaing press M. 27-326 300T 40

- Dake Corporation Model 27-417 400T 75

- Dake Corporation Model 27-418 500T 75

- Dako Corporation Model 27-419 600T 75

-C-Frame or gap: 15 tons or under

- Dake Corporation Norta-Matic Press 4T

- Dake Corporation Norta-Matic Press 6T

- Dako Corporation Norta-Matic Press $12 T$

- Greenerd Press \& Machine Co. Model HA-4-5 4T

- Greenerd Press \& Machine Co. Model HA-4-8L2 $4 T$

- Greenerd Press \& Machine Co. Model HA-8-8 8T 


\section{Appendix B: (contd)}

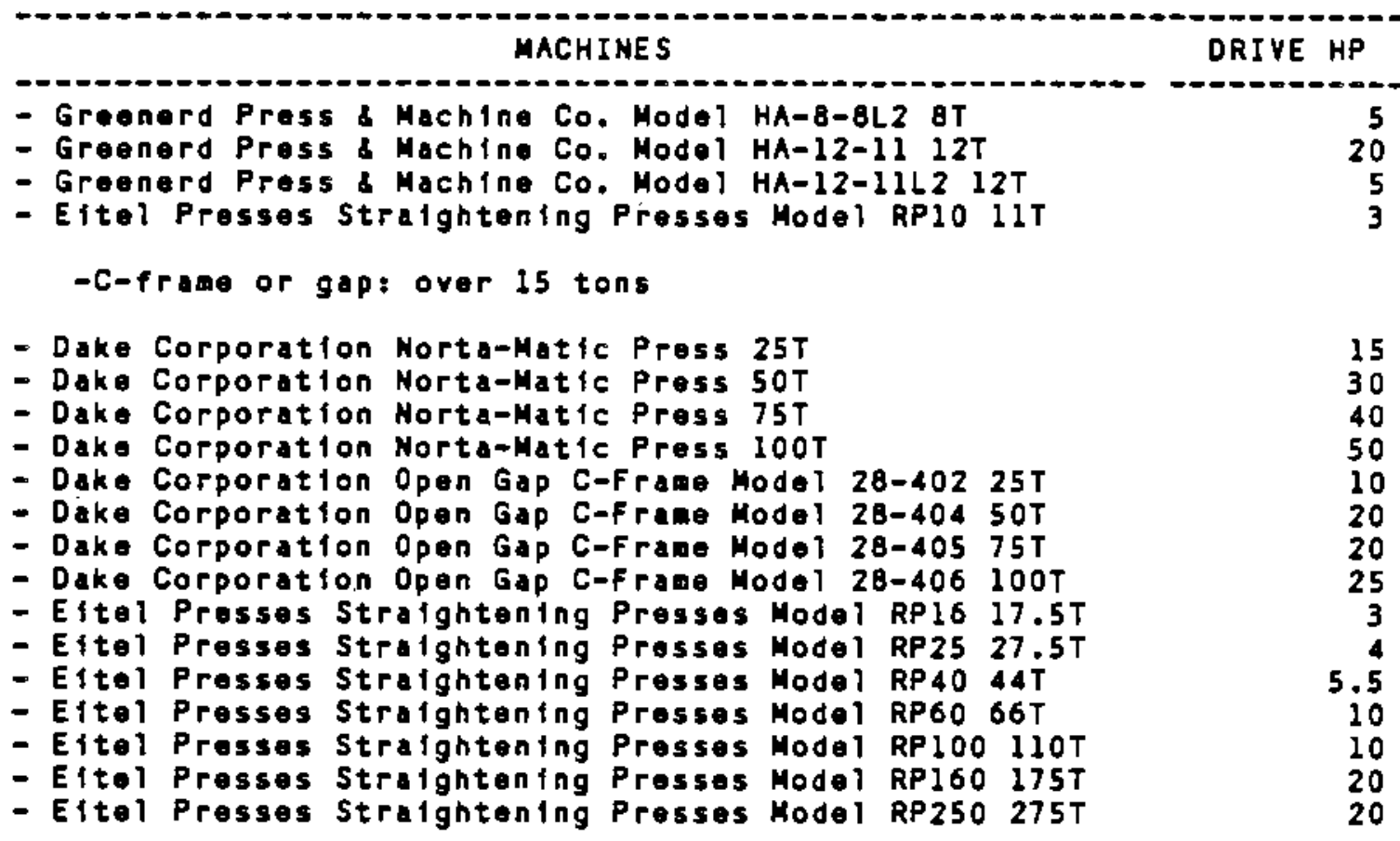

-Vertical, double action

- Dake Corporation Movable Framo Pross Model 19-435 25T 2

- Dake Corporation Movable Frame Press Model 19-436 $50 \mathrm{~T}$

- Dake Corporation Movable Frame Press Model 19-437 75T 2

- Dake Corporation Movable Frame Press Model 19-438 150T 10

- Dake Corporation H Frame Heavy Duty. Mod. 23-380 25T 10

- Dake Corporation H Frame Heavy Duty, Mod. 23-381 50T 10

- Dake Corporation H Frane Heavy Duty. Mod. 23-382 50T 10

- Dake Corporation H Frame Heavy Duty, Mod. 23-383 125T 10

- Dake Corporation H Frame Heavy Duty, Mod. 23-384 150T 10

- Dake Corporation H Frame Hesvy Duty, Mod. 23-385 200T

- Dake Corparation H Frade Heavy Duty, Mod, 23-386 250T 10

- Oake Corporation H Fraee Heavy Duty, Mod. 23-387 300T

- Dake Corporation H Frame Heavy Duty, Mod. 23-388 400T 20

- Dake Corporation H Frame Heavy Duty, Mod, 23-389 500T 25

- Dake Corporation H Frane Heavy Duty, Mod. 23-390 600T 30

\subsection{COIL PROCESSING SYSTEMS}

- Ruesch Machine Co. Model No. 149 S11tter 25

- Rueseh Machine Co. Model Mo. 129 Roliling Mill 40

\subsection{THREAD ROLLING MACHINES}

- Teledyne Landis Machine Moder loTRM

- Teledyne Lands Machine Model Lanhyrol

- Teledyne Landis Machine Modei 32TFRI 
APPENDIX C

SPINDLE DRIVE HORSEPOWER OF SELECTED MACHINE TOOLS 
Appendix C: Spindle Drive Horsepower of Selected Machine Tools

MACHINE TYPE

\section{1. metalcutting machines}

DRIYE HORSEPOHER

L $H \quad A$ ( $h p)(h p) \quad(h p)$

(hp) -

1.1 NC TURNING MACHINES

- Horizontal under g" chuck

-Horizontal gn to undor 13n chuck

-Horizontal 13" to under 20" chuek

-Horizontal 200 chuck and larger

- Yertical turn \& bore (YTM, YBM)

$\begin{array}{rrr}7.5 & 20 & 13.75 \\ 30 & 50 & 40 \\ 20 & 50 & 35 \\ 40 & 60 & 50 \\ 75 & 150 & 112.5\end{array}$

1.2 NOH HC TURNING MACHINES

-Eng 8 tlre (not tracer) over B= to 16" swing

-Eng \& tira (not tracer) over 16* suing

$4 \quad 7.5 \quad 5.75$

-Tracer lathes (alistzas)

1.3 HC BORING MACHINES

-Hozizontal bore, driti, will (bar machining)

8

1.4 NON NC BORING MACHINES

-Hor. bore, drili, alli (bar mach) table a planer type

-Hor. bore, drill, -111 (bar mach) floor type

-Precison, horizontal and vertical

$\begin{array}{rrr}8 & 10 & 9 \\ 50 & 70 & 60 \\ 87 & 120 & 103.5\end{array}$

1.6 MON NC DRILLING MACHINES

-Radial

1.7 NC MACHINING CENTERS

-Automatic tool changa: vertleal Y-axis 26" or loss

-Autoratic tool change: vertical $Y$-axis over $26 \mathrm{~m}$

-Automatic tool change:

-Automatic tool change: horfzontal Y-axis $27 n$ or over

1.8 HC MILLING CENTERS

-Profiling and duppilicating

1.9 MON NC MILLIMG MACHINES

\footnotetext{
-General purpose, knee or bed: vertical

-General purpose, knee or bed: horizontal

- Automatic and nanufaeturing
}

$\begin{array}{rrr}3 & 10 & 6.5 \\ 7.5 & 10 & 8.75 \\ & 22.5 & 11.25\end{array}$


Appendix C: (contd)

HACHINE TYPE

1.10 GEAR CUTTING AND FINISHING MACHINES

- Gear hobbers

-Gear shapers

1.II NC GRINDING MACHINES (ALL TYPES)

1.12 NON NC GRINDING MACHINES

-External: plain conter type

-External: universal center type

-External: conteriess (including shoe type)

-External: chucking

-Surface: reciprocating, vertical and horizontal, pover

- Tool and cutter

- Bench, floor and saag

-Disk grinders, single and double spindle

-Abrasive belts (axcept finishing)

1.13 HONING, LAPPING, PDLISHING MACHINES

-Polishing stands (inct. abrasive belts-not grinding)

1.17 CUTOFF AND SAHING MACHINES

-Abrasive wheols

-Band sars, countour sawing and filing

\section{METALFORMING MACHINES}

2.2 NC PUNCHING \& SHEARING MACHINES

-Punching achines (1nct. comb. puncting shearing)

-Plate and sheot shears: hydraulic

$\begin{array}{rrr}0.5 & 15 & 7.75 \\ 3 & 25 & 14\end{array}$

2.4 NON NC BENDING AND FORMING MACHIMES (POHER)

-Press brakes: mechanical

-Press brakes: hydraulic and pneumatic

-Bending rolis, sheet and plate

-Bending rolis, angles, bars, shapes. pipes

-Rotary bending and forwing wachines

-Ram and press bending aachines

\subsection{MECHANICAL PRESSES-PONER (NOT FORGES)}

-Dpen back (OBI) dgap: 51 tons and over

- Yertical stralght side or archisingle polnt

-Tro point: 300 tons or under

-Two polnt: 301 tons or over
DRIYE HORSEPOWER

L $H \quad A$

(hp) (hp) (hp)

(hp) (hp) (hp)

$\begin{array}{rrr}24 & 37 & 30.5 \\ 3 & 12 & 7.5 \\ 1.5 & 30 & 15.75\end{array}$

$\begin{array}{rrr}20 & 25 & 22.5 \\ 7.5 & 13 & 10.25 \\ 15 & 50 & 32.5 \\ 5 & 15 & 10 \\ 5 & 19 & 12 \\ 1 & 1.5 & 1.25 \\ 0.33 & 5 & 2.665 \\ 3 & 20 & 11.5 \\ 5 & 100 & 52.5\end{array}$

$1 \quad 10 \quad 5.5$

$10 \quad 60 \quad 35$

$110 \quad 5.5$

$\begin{array}{rrr}3 & 20 & 11.5 \\ 3 & 10 & 6.5 \\ 2 & 25 & 13.5 \\ 3.5 & 100 & 51.75 \\ 0.75 & 1.25 & 1 \\ 20 & 25 & 22.5\end{array}$

$\begin{array}{rrr}15 & 30 & 22.5 \\ 5.5 & 50 & 27.75 \\ 10 & 40 & 25 \\ 30 & 40 & 35\end{array}$


Appendix C: (contd)

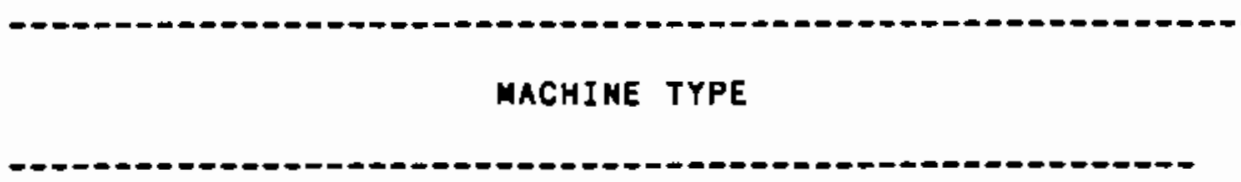

DRIVE HORSEPOWER

L H A

(hp) (hp) (hp)

2.6 HYDRAULIC PRESSES (NOT FORGES)

-Vartical, stralght side or column

-C-Frame or gap:15 tons or under

-C-frame or gap: over 15 tons

-Vartical, doublo action

--o- -o-- - - - -

2.8 COIL PROCESSING SYSTEMS

\subsection{THREAD ROLLING MACHINES}

$\begin{array}{rrr}7.5 & 75 & 41.25 \\ 3 & 20 & 1 i .5 \\ 4 & 40 & 22 \\ 10 & 20 & 15 \\ 25 & 40 & 32.5 \\ 3 & 20 & 11.5\end{array}$

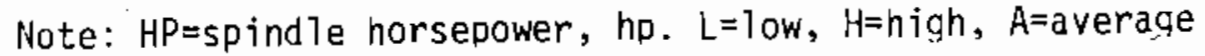




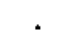


DISTR IBUT ION

No. of

Copies

OFFSITE

12 T. Levinson

U.S. Department of Energy

Forrestal Building CE-142

Washington, D.C. 20585

30 DOE Technical Information Center

A. Anderson

Multi-Arc Vacuum Systems Inc.

261 East 5th Avenue

St. Paul, MN 55101

C. Albertson

Borg-Warner Corporation

1200 South Wolf Road

Des Plaines, IL 60018

A. Becker

Alumina, Chem. \& Ceramics Division

A1 coa Research Laboratories

Alcoa Center, PA 15069

P. N. Bl umberg

Integral Technologies, Inc.

415 East Plaza Drive

Westmont, IL 60559

L. J. Brombolich

Compu-Tec Engr. Inc.

300 Chesterfield Center, 205

Chesterfield, M0 63017

W. Bryzik

U.S. Army TACOM

AMSTA-RGR

Warren, MI 48090

D. H. Ruckley

NASA/Lewis Research Center

23-2

Cleveland, $\mathrm{OH} \quad 44135$
No of

Copies

R. F. Bunshah

Department of Materials Science

University of California at

Los Angeles

6532 Boelter Hall

Los Angeles, CA 90024

J. A. Carpenter, Jr.

Oak Ridge National Laboratory

P0 Box $X$, Building 4508

Oak Ridge, TN 37831

D. C. Classen

Caterpillar Tractor Co.

Mfg. Engr. Building W

600 West Washington Street

East Peoria, IL 61630

F. J. Carignan

Advanced Mechanical

Technology Inc.

141 California Street

Newton, MA 02158

D. L. Cocke

Texas A\&M University

Department of Chemistry

College Station, TX 77843-3255

H. S. Cheng

Dept. of Mechanical Engineering

Center for Engineering

Tribology

Northwestern University

Evanston, IL 60201

G. W. Clark

Oak Ridge National Laboratory

P0 Box $X$, Building 4508

Dak Ridge, TN 37831

G. Chang

29615 Lincoln Road

Bay Village, $\mathrm{OH} 44140$ 
No of

Copies

M. J. Cronin

Mechanical Technology, Inc.

968 ATbany-Shaker Road

Latham, NY 12110

J. L. Duda

Pennsylvania State University

133 Fenske Laboratory

University Park, PA 16802

S. K. Das

Materials Laboratory

Allied Corporation

P.0. Box $1021 \mathrm{R}$

Morristown, NJ 07960

J. F. Dill

Mechanical Technology Inc.

968 Albany-Shaker Road

Latham, NY 12110

R. L. Dasilveira

Eutectic Corp.

4040172 nd Street

Flushing, NY 11358

J. J. Eberhardt

U.S. Department of Energy

Forrestal Building

Mail Stop 68025

Washington, D.C. 20585

C. A. Ebel

High Performance Ceramics

Norton Company

1 New Bond Street

Worcester, MA 01606

R. Erickson

Battelle-Columbus Laboratory

505 King Avenue

Columbus, OH 43201-2693

L. L. Fehrenbacher

2002 Huntwood Drive

Huntington Woods

Gambrills, MD 21054
No of

Copies

D. G. Flom

Generat Electric Company

Corporate R\&D, 4B4, K-1

P.0. Box 8

Schenectady, NY 12301

T. Fischer

Exxon Research

Clinton Township Route 22 East

Annandale, NJ 08801

P. Grayson

Eagle Picher Industries, Inc.

P. 0. Box 1090

Miami, OK 74354

J. Graham

Deere and Company

Technical Center

3300 River Drive

Moline, IL 61265

S. Goguen

U.S. Department of Energy,

$$
\text { CE } 131
$$

Mailstop 5E 043

Forrestal Building

1000 Independence Ave., SW

Washington, D.C. 20585

R. M. Gresham

$E / M$ Lubricants, Inc.

P.0. Box 2200, Highway 52 N.W.

West Lafayette, IN 47906

J. Horwath

Borg-Warner Corporation

Ingersoll Research Center

1200 S. Wolf Road

Des Plaines, IL 60018

S. M. Hsu

Room A257, Building 223

Inorganic Materials Division

National Bureau of Standards

Gaithersburg, MD 20899 
No of

Copies

N. S. Hakim (RO3B)

Detrojt Diesel Allison Division

36880 Ecorse Road

Romulus, MI 48174

C. R. Houska

Dept. of Materials Engineering

Virginia Polytechnic Institute

Blacksburg, VA 24061

R. A. Harmon

25 Schalren Drive

Latham, NY 12110

1. K. Hirvonen

Spire Corporation

Patriots Park

Bedford, MA 07130

10 M. Kaminsky

Argonne National Laboratory

9700 South Cass

Argonne, IL 60439

E. E. Klaus

Dept. of Chemical Engineering

Pennsylvania State University

University Park, PA 16802

R. Krutenat, 102/0217

Exxon Research and

Engineering $\mathrm{Co}$.

Florham Park, NJ 07932

S. Khanna

Solid State Science Research Group

Jet Propulsion Laboratory

4800 Oak Grove Drive

MS ?22-123

Pasadena, CA 91109

12 H. K. Le

DHR , Inc.

6849 01d Dominion Drive

McLean, VA 22101
No of

Copies

K. Ludema

University of Michigan

Dept. of Mechanical Engineering

2024 G. G. Brown

Ann Arbor, MI 48109-2125

Librarian

Deere and Company

Technical Center

3300 River Drive

Moline, IL 61265-1792

F. F. Ling

Mechanical Engineering

Jonsson Engineering Center

Rensselaer Polytechnic Institute

Troy, NY 12181

H. E. McCormick

Director of Engineering

Ramsey Piston Ring Division

TRW Automotive Products, Inc.

1233 Manchester Road

Manchester, M0 63011

C. Mecklenburg

AFWAL/MLBT

Wright Patterson AFB

Dayton, $\mathrm{OH}$ 45433-6533

J. McCool

SKF Industries

1100 First Avenue

King of Prussia, PA 19406

R. W. Meyerhoff

Union Carbide Corporation

Coatings Service

1500 Polco Street

Indianapolis, IN 46224

J. R. Mutlaly

Pratt \& Whitney Aircraft

P.0. Box 2691

MS 707-28

West Palm Beach, FL 33402 
No of

Copies

P. Madden

SKF Industries

1100 First Avenue

King of Prussia, PA 19506

M. B. Peterson

Wear Sciences, Inc.

925 Mallard Circle

Arnold, MD 21012

0 . Pinkus

Mechanical Technology Inc.

968 Albany-Shaker Road

Latham, NY 12110

T. F. J. Quinn

Tribology and Rheology

Laboratory

School of Mechanical

Engineering

Georgia Institute of Technology

At lanta, GA 30332

R. C. Rosenberg

General Motors Research Laboratory

Fluid Mechanics Department

Warren, MI 48090

D. A. Rigney

The Ohio State University

Dept. of Metallurgical

Engineering

141A Fontana Laboratories

116 West 19th Avenue

Columbus, $\mathrm{OH}$ 43210-1179

A. W. Ruff

National Bureau of Standards

Metallurgy Division

Room B266-Materials Building

Gaithersburg, MD 20899

W. D. Sprout

Borg-Warner Corporation

1200 South Wolf Road

Des Plaines, IL 60018
No of

Copies

\author{
P. Sutor \\ Midwest Research Institute \\ 425 Volker Boulevard \\ Kansas City, M0 64110 \\ L. B. Sibley \\ Tribology Consultants, Inc. \\ 504 Foxwood Lane \\ Paoli, PA 19301
}

A. C. Schaffhauser

Oak Ridge National Laboratory

P.0. Box $X$

Oak Ridge, TN 37831

I. L. Singer

Naval Research Laboratory

Code 6170

Washington, D.C. 20375

G. L. Starr, Manager

Metallurgical Engineering

Cummins Engine Technical Center

Box 3005

Columbus, IN 47202-3005

R. STone 50165

Cumtins Engine Technical Center

Box 3305

Columbus, IN 47202-3005

T. C. Spaivins

NASA/Lewis Research Center

MS 23-2

Cleveland, $\mathrm{OH} 44135$

M. Shaw

Arizona State University

ECG 247, Mechanical Engineering

Tempe, AZ 85287

P. Swanson

John Deere Company

Technical Center

3300 River Drive

Moline, IL 61265 
No of

Copies

L. D. Wedeven

SKF Industries, Inc.

1100 First Avenue

King of Prussia, PA 19406

R. Ted Wimber

Deere and Company

Technical Center

3300 River Drive

Moline, IL 61265-2792

D. :. Wi1cock, President

Tribolock, Inc.

194') Hexham Road

Schinectady, NY 12309

W. 1). Winer

Tribology and Rheology Laboratory

Schuol of Mechanical

Engineering

Georgia Institute of Technology

AtTanta, GA 30332

D. Kuhlman-WiT sdorf

University of Virginia

Physics Department

McCormick Road

Charlottesville, VA 22901

W. F. Winnard

Battelle Memorial institute

2030 M. Street NW

Washington, D.C. 20036

C. S. Yust

Metals and Ceramics Division

Oak Ridge National Laboratory

P.0. Box $X$

Oak Ridge, TN 37831

T. M. Yonushonis

Cummins Engine

Mait Code 50183, Box 3005

Columbus, IN 47202-3005
No of

Copies

M. Zlotnick

141 East 88th Street

New York, NY 10028

C. A. Zanis

Department of the Navy

Naval Sea Systems Command

Research and Development Office

Washington, D.C. 20362

FOREIGN COUNTR IES

Dr. Jochen P. Biersack

Glienicker Strabe 100

1000 Berlin 39

West Germany

Or. Erich Bergmann

Balzers Aktiengesel lschaft

FL-9496 Baizers

Furstentum, Liechtenstein

Professor Or. H. Czichos

Federal Institute for Materials

Research and Testing

Unter den Eichen 87

D-1000 Berlin 45

West Germany

Dr. Geoff Dearnaley

Nuclear Physics Division

Building $\mathrm{H} 8$

AERE Harwe 11

Didcot, Oxfordshire

United Kingdom OX 11 ORA

Dr. Hans E. Hintermann

Laboratoire Suisse de

Recherches Horlogeves

$\mathrm{CH}-2000$ Neuchatel

Switzerland 
No of

Copies

Dr. Richard Horton, Manager

Energy Conservation Technology Centre

Engineering Sciences Division B151 Harwell Laboratory

Oxfordshire OX 11 ORA

England

Dr. Boris Navinsek

Jozef Stefan Institute

61001 Ljubljana

Jamova 39

Yugoslavia

Prof. Or. ir. J. Roos

Katholieke Universiteit Leuven

Department Metaalkunde

de Croylaan 2

B-3030 Leuven (HeverTee)

Belgium

Dr. S. Veprek

Anorganisch-Chemisches

Institut der Universitat Zurich

Winterthurerstrasse 190

8057 Zurich

Switzerland
No. of

Copies

ONSITE

DOE Richland Operations Office

H. E. Ransom/D. R. Segna

12 Pacific Northwest Laboratory

D. L. Brenchley

C. H. Imhoff

D. C. Kuick

J. A. Russell

M. T. Thomas

Publishing Coordination MH (2)

Technical Information (5) 